UNIVERSIDADE DE SÃO PAULO
FACULDADE DE FILOSOFIA, LETRAS E CIÊNCIAS HUMANAS

ROSEMEIRE FRANÇA DE ASSIS RODRIGUES PEREIRA

\title{
O LETRADO E O ÓBOLO - VIEIRA E A JUSTIFICAÇÃO DA POBREZA
}

TESE DE DOUTORAMENTO APRESENTADA À FACULDADE DE FILOSOFIA, LETRAS E CIÊNCIAS HUMANAS DA UNIVERSIDADE DE SÃO PAULO COM VISTAS À OBTENÇÃO DE TÍTULO DE DOUTORA

ORIENTADOR: PROF. DR. EDUARDO DE ALMEIDA NAVARRO ÁREA DE LITERATURA BRASILEIRA DEPARTAMENTO DE LETRAS CLÁSSICAS E VERNÁCULAS

SÃO PAULO

abril de 2012 


\section{RESUMO}

A presente pesquisa tem como objetivo analisar os escritos do jesuíta Antônio Vieira a partir do recorte temático da pobreza e de sua estreita ligação com o pensamento religioso vigente. Considerando o grande volume de escritos, tanto sermões quanto epístolas e apontamentos históricos, selecionamos aqueles que mantêm relação mais próxima com o tema proposto. A fim de discutirmos essa problemática, buscamos historiadores que discorreram sobre o século XVII, abordando prioritariamente a questão da pobreza, da indigência e da bastardia. A ligação dos discursos históricos e documentais com outros escritos do autor nos revelou as dinâmicas das sociedades gestadas pelos portugueses e a tentativa desses de se inserirem na modernidade, repensando a organização econômica e redesenhando o panorama social de Portugal.

\section{ABSTRACT}

This research aims to analyze the writings of the Jesuit Antonio Vieira about poverty, inasmuch they are related to religious thoughts in that period. Considering the quantity of writings, either speeches or letters, we have selected those ones keeping closer relationships to that theme. Discussing this issue, we have researched about XVII Century, focusing mainly the poverty, misery and bastardy. The close relationships of historical and documental speeches to Vieira's writings reveal us how was the society managed by the Portuguese and how they tried to insert themselves in the Modernity, rethinking the economical organization and redrawing the social panorama in Portugal. 


\section{ÍNDICE}

INTRODUÇÃO

CAPÍTULO I

A organização social portuguesa no século de Vieira à luz do

Sermão de Santo Antônio e de outros sermões.

CAPÍTULO II

O Sermão das Obras de Misericórdia: O pobre como o próprio Cristo

CAPÍTULO III

O Sermão da Visitação de Nossa Senhora

a Santa Isabel: O pobre, receptáculo do favor divino

71

\section{CAPÍTULO IV}

Sermão XIV do Rosário: A pobreza do

cativeiro é a senda da salvação

CAPÍTULO V

Epifania e Espírito Santo - A pobreza no índio 101

1. Novo Mundo - Paraíso infernal 111

2. Pobre índio pobre

\section{CAPÍTULO VI}

Sermão de São Roque: Quando a pobreza

compromete a soberania

CONCLUSÃO 
À ardente memória de minha avó, Maria Nunes França, mulata guerreira que me marcou com 0 legado do espírito de resistência. 


\section{AGRADECIMENTOS}

Minha eterna gratidão a Deus

Meus sinceros agradecimentos ao meu único amigo de bordo, professor Eduardo de Almeida Navarro 


\section{INTRODUÇÃO}

Traço marcante na cultura brasileira, a aceitação da pobreza como condição estabelecida pela religiosidade motivou-nos a mergulhar nos escritos de Vieira, a fim de entender a concepção de pobreza no ideário setecentista e sua extensão nos séculos seguintes.

Vieira não foi apenas um padre jesuíta e exímio escritor, mas um grande articulador político e social no Brasil e em Portugal, um grande formador de ideias no século XVII. Não obstante a sua influência política no cenário europeu de então, encarava a questão da pobreza por uma perspectiva absolutamente teológica. A visão de mundo de Vieira pode-nos conduzir a uma perspectiva de compreensão da formação cultural e social de Portugal e do Brasil. Suas idéias lançam luzes sobre como se formou a ideia da pobreza "digna", elemento de nossa cultura tradicional, católica e patriarcal, tão distante da concepção protestante, notadamente calvinista, de que a riqueza é sinal da predestinação divina.

Assim, diante da crescente preocupação que existe hoje em se conhecerem as dinâmicas das organizações sociais desse período e, por meio delas, chegar-se à compreensão dos impasses sóciopolíticos peculiares aos países ibéricos, a obra do grande orador jesuíta é um dos mais valiosos documentos para tal empreitada, mas requer de seus pesquisadores análise ampla e profunda do contexto da época no qual se inserem seus escritos. 
Esta pesquisa propõe investigação dos escritos do Padre Antônio Vieira por meio de um recorte temático: a pobreza. Não temos aqui a intenção de contestar tudo o que já se escreveu sobre o autor, mas a de oferecer uma diretriz diferente de investigação, considerando-se que já muito se discorreu sobre certos assuntos, como, por exemplo, o messianismo de Vieira, tendo como base o instigante tema do Quinto Império. Tencionamos, agora, desenvolver um percurso diferente, a partir de uma temática pragmatista da obra desse notável jesuíta.

Temos consciência das dificuldades que teremos de superar, pelo fato de não podermos analisar a pobreza como tema estanque dentro de uma obra tão rica e toda envolta em impressões teológicas. A pobreza é discutida por Vieira como um dos fios da ideologia que a dominava. Por isso, tentaremos mostrar o tom de aceitação da condição do pobre dentro de seus sermões, componente de um ideário que garantia a ordem social no século XVII e impossibilitava a transformação social.

Ao pensar em tudo quanto já se escreveu sobre Antônio Vieira, sentimo-nos num imenso labirinto, não somente pela profusão de estudos desenvolvidos sobre ele no mundo todo, mas principalmente pela complexidade de seu discurso, no qual residem, em singular coerência e harmonia, a teologia, a política e as questões humanas mais variadas. Buscamos, assim, imaginar algo diferente de tudo quanto já se comentou sobre o grande orador. Estando diante de um projeto de doutorado, dever-se-ia procurar, com efeito, um tema inédito. Felizmente as questões com as quais estamos envolvidos 
sempre nos suscitam questionamentos e é por meio deles que conseguimos exercitar nossa criatividade. Foi assim que encontramos em Vieira um tema que muito nos incomoda: a pobreza. É claro que não o foi por intermédio da leitura do próprio Vieira, mas foi pesquisando sobre os índices da Contra-Reforma nas artes plásticas (século XVII) que encontramos numa tela de El Grecco uma diretriz segura para nosso projeto: a tela que representa São Martinho e o pobre. A imagem daquele pobre nu diante da nobreza de São Martinho perseguiu-nos por muitas noites. Passamos a procurar em Vieira, às cegas, algo que pudesse relacionar àquela imagem. Encontramos em vários sermões fragmentos sobre o tema, porém nada muito profundo. Mesmo assim, não desistimos, até que, numa das suas orientações, 0 professor Eduardo Navarro teceu um comentário sobre o Sermão das Obras de Misericórdia (1647). Encontramos ali o núcleo da nossa pesquisa e percebemos quão instigante poderia ser esse tema. Ignoramos a existência de alguma pesquisa sobre a temática da pobreza em Vieira, mas sabemos que, depois daquele momento, deparamo-nos com um Vieira diferente, não transcendente em seu discurso intrincado, porém humano, frágil, conduzido pelas idéias contrarreformistas, que consistiam na mais absoluta verdade das elites seiscentistas.

O manto da complexidade de Vieira foi-se rompendo aos poucos quando passamos a fazer analogia desse sermão com outros, como o da Epifania (1662), o XIV Maria Rosa Mística (1633), o da Sexagésima (1655), o do Espírito Santo (1657), o de Santo 
Antonio aos Peixes (1654), o de São Roque (1644) e muitos outros. Em todos eles há uma concepção particular de pobreza, uma análise distinta que se desenha conforme o contexto e o objeto para os quais o orador se dirige. O Sermão das Obras de Misericórdia trata da pobreza dentro do contexto social português e nos revela uma face tridentina pouco estudada, porém, primordial para a composição da cultura nos domínios portugueses. O texto refere-se aos pobres europeus, aqueles que, por infortúnio ou por destinação histórica, mendigavam o pão nas escadarias dos templos e nas praças. Essa visão da pobreza configurou-se na Idade Média e alcançou os Seiscentos, preservada pelo pensamento da Contrarreforma, que vê no pobre oportunidade para a salvação do rico. Atentamos à análise moderna de Michel de Foucault ${ }^{1}$ que, diferentemente de Vieira, discorre sobre essa face da pobreza e a grande oportunidade que os ricos encontravam de ostentar sua fé por meio da organização de confrarias, instituições disseminadas progressivamente a partir do século XVI, limiar da Modernidade, que fez despertar, pela primeira vez, a ideia da pobreza como desajuste social. Essas "sociedades", genuinamente clericais, geriam as despesas dos orfanatos, hospícios, depósitos para desabrigados e desvalidos; cuidavam da distribuição das esmolas e arrolavam os pobres de cada cidade. No decorrer de nossa pesquisa, abordamos exatamente a função dos hospícios ou hospitais, que, na época, exerciam a mesma função, mas que não correspondiam exatamente aos hospitais e hospícios que conhecemos hoje.

\footnotetext{
${ }^{1}$ Vigiar e Punir
} 
No Brasil, encontramos Vieira a realizar apologia às confrarias das obras de misericórdia da Bahia por meio do Sermão da Visitação de Nossa Senhora a Santa Isabel, escrito em 1638, a fim de refletir sobre a vitória dos brasileiros sobre os holandeses quando tentaram invadir a Bahia. Aqui o autor discute principalmente a questão da partilha dos despojos e afirma que os pobres devem receber as primícias desses bens porque lutaram e se avariaram durante a batalha. Pode-se perceber que não há condição de ler Vieira sem compreender os fatos históricos que envolviam cada um de seus sermões ou de seus escritos. Essa questão pareceu-nos clara, porém acrescentou ainda mais a responsabilidade de estudar a obra desse jesuíta.

Mesmo assim, pareceu-nos interessante observar que a pobreza em Vieira adquire várias facetas, muito distintas dessa representada no Sermão das Obras de Misericórdia que, numa interpretação simplificada, corresponde apenas à pobreza material, à carência de bens palpáveis, à ausência de fazenda própria. Para Vieira, há também a pobreza de razão, analisada no Sermão da Epifania, que acarreta, entre outros males, as dúvidas acerca da humanidade dos índios, visto que são descritos como "gente menos gente de quantas nasceram no mundo" ${ }^{2}$. Considerando-se a análise tomista, que rege a Segunda Escolástica, de que razão remete à inteligência, que remete à alma, que remete ao contato com Deus, entende-se o discurso de Vieira quando acomoda o gentio à mais vil classificação do gênero humano. Seria, por conseguinte, a nação

\footnotetext{
${ }^{2}$ Sermão da Epifania, (Organização de Alcir Pécora): p. 611.
} 
com mais remotas possibilidades de salvação, talvez a pobreza mais profunda descrita pelo autor. Pécora (2008) avalia os exageros de Vieira como uma supervalorização do trabalho da catequese. Assim, quanto mais rude e boçal for o índio, mais valor terá o trabalho dos missionários. ${ }^{3}$ Esse mesmo assunto é retomado no Sermão do Espírito Santo, no qual o gentio é comparado à estátua de murta por ser gente "mais bruta, mais ingrata, mais inconstante, mais avessa, a mais trabalhosa de ensinar de quantas há no mundo"A. Percebe-se que, apesar de estar numa posição aquém da organização social da época, o índio padece de uma pobreza que fatalmente o condenará à mais baixa posição da sociedade vindoura pois, na ideologia contrarreformista, a pobreza espiritual era uma maldição eterna, que predestinaria suas vítimas a um infortúnio resistente por muitas gerações. Acusamos registros do século XVI, nomeadamente as Atas da Câmara da Cidade de São Paulo, onde constatamos a condição de pobreza material em que viviam os índios aldeados e administrados, os quais eram proibidos de realizar comércio e portar dinheiro. Constatamos também a pobreza dos colonos brancos no Planalto de Piratininga, cuja única possibilidade de riqueza residia no apresamento e escravização do nativo. E é diante dessas dificuldades intransponíveis, a falta de razão nos povos americanos como a principal delas, é que o português cumpre sua caridade e misericórdia. O óbolo que se oferece em tal situação é a cristianização. Malgrado a aridez e a esterilidade dos campos, a tentativa de conversão se materializa por meio das missões.

\footnotetext{
${ }^{3}$ Pécora, Alcir. "O Bom Selvagem e o Boçal" in Vieira, vida e palavra, p: 64

${ }^{4}$ Sermão do Espírito Santo: p. 422.
} 
Outra manifestação de miséria presente no discurso vieirense é aquela relativa à escravidão negra, descrita na série dos sermões do Rosário. Trata-se da união dos negros numa confraria que tinha por finalidade a devoção ao Rosário da Virgem. Se, para Vieira, era apenas um instrumento de conversão, para alguns historiadores era a única maneira de o negro deixar uma vez por ano o cativeiro, ir a festas religiosas e se comunicar com seus pares de outros engenhos. Analisando-se tal texto, percebe-se que a escravidão negra converte-se em ato de caridade a partir do momento em que possibilita ao africano o contato com o Cristianismo e a participação da salvação por intermédio do sacrifício de Cristo na cruz. Nesse contexto, a captura, o transporte e a comercialização das gentes africanas é o óbolo da misericórdia que as integrará à Cristandade.

Analisamos também, nos sermões de Vieira, a miséria de caráter, que já naquela época imperava nas terras americanas. Com efeito, encontra-se no Sermão do Bom Ladrão referência a um julgamento equivocado de um ladrão rico, que pode restituir os bens fraudados, e o ladrão pobre, que só depende da misericórdia de Cristo para ser perdoado de seu crime. O rico compra sua redenção mediante o dinheiro, o pobre caminha para a forca por não ter meios de restituir o pão que furtou. Nesse contexto, o ladrão pobre será sempre ladrão, carregará por muitas gerações o estigma de sua ação, enquanto o ladrão rico será coroado de louros e tratado sempre como fidalgo, assim como seus filhos. Entretanto, analisa 
Vieira, os ladrões mais dignos desse título não são "aqueles que roubam um homem, mas aqueles que roubam cidades e reinos". ${ }^{5}$

Diante de todas essas formas de pobreza, observa-se que, excetuando-se a de caráter, todas as outras conduzirão a um ponto comum: à pobreza material. O mendigo ocupará eternamente sua condição numa sociedade avessa à mobilidade. $O$ índio, por não ter razão, jamais possuirá as fazendas que tanto enobrecem o homem ocidental. O africano carregará para sempre o estigma da exclusão e seu cativeiro o acompanhará como castigo.

As investigações humanas presentes no discurso de Vieira não são fruto apenas de sua longa vida de oitenta e nove anos, nem de sua intensa vivência, com muitas viagens pela Europa, mas, é resultado de sua natureza inquieta e inconformada e de sua sensibilidade ímpar. O seu "olhar de girassol" é capaz de enxergar e analisar os homens em seus mais remotos esconderijos. Sua organização mental é capaz de conceber uma ideia e uma categorização para cada situação. Dessa forma, a nossa proposta primeira de investigar apenas a pobreza material em Vieira alterouse diante da ampliação dos objetivos a que nos conduziu a leitura de seus sermões. Aprendemos, com o grande orador, as inúmeras faces da pobreza e seus diversos remédios. O óbolo que, na nossa concepção inicial, limitava-se à moeda, à mera esmola, expande-se em atitudes e situações criadas no contexto colonial e colonizador.

Poderia citar, ainda, muitos outros sermões que entretêm relações seguras com o tema da pobreza, como o Sermão de Santo

\footnotetext{
${ }^{5}$ Sermão do Bom Ladrão: p. 396.
} 
Antonio aos Peixes e o da Primeira Dominga da Quaresma. Além disso, julgamos ser interessante também realizar análises das cartas e dos escritos históricos do autor, buscando melhor fundamentar esse tema, tratado nos sermões de maneira mais objetiva.

Além do já referido Sermão das Obras de Misericórdia que deu origem ao capítulo nuclear desta tese e a todos os demais, devidamente citados, iniciamos com uma singela análise da organização social em Portugal e seus domínios. Pareceu-nos primordial compor, mesmo que de maneira sintética, a estrutura social naquele século e analisar a maneira como a pobreza foi-se estabelecendo no universo luso. A evidência dos traços culturais ibéricos na composição da pobreza deixam claras as diversas peculiaridades de uma sociedade regida pela religiosidade medieval, mas que, ao mesmo tempo, tentava por todos os meios inserir-se na Modernidade, adotando formas de enriquecimento e busca de privilégios. 


\title{
CAPÍTULO I
}

\section{A ORGANIZAÇÃO SOCIAL PORTUGUESA NO SÉCULO DE VIEIRA À LUZ DO SERMÃO DE SANTO ANTÔNIO E DE OUTROS SERMÕES}

\begin{abstract}
Não é tarefa simples expor didaticamente os estamentos sociais existentes no Brasil do século XVII ou em qualquer domínio português dessa época. Contudo, tentaremos apresentar uma singela escala das camadas sociais, o que se faz necessário, pois precisamos situar o pobre, tanto no Reino português quanto no Brasil e, ainda, no recém-fundado Estado do Maranhão e Grão-Pará. Para isso, pensamos ser interessante tomar como embasamento para o início desta reflexão o Sermão de Santo Antônio, escrito em 1642 e pregado na Igreja das Chagas de Lisboa. Por ele é possível estabelecer ligação segura entre as várias esferas da composição do Reino de Portugal, não apenas social, mas política e econômica.

Nos capítulos onde analisamos os sermões de Vieira podemos constatar sua descrição de pobreza relativa ao branco - no Sermão das Obras de Misericórdia; aquela concernente ao escravo africano - especificamente no Sermão XIV do Rosário; a miséria do índio detalhada nos sermões da Epifania e Espírito Santo. Em se tratando de Vieira, porém, sabemos que referências aos pobres encontram-se por muitos dos seus escritos, sejam cartas ou documentos históricos. É importante observar, sobretudo, que, apesar das constantes referências ao índio e ao negro, sabe-se que os primeiros, por serem
\end{abstract}


tutelados, não estavam devidamente estabelecidos na organização social vigente; os últimos, sendo escravos, não eram nada mais que mercadorias e chamados de peças nos documentos da época. Conforme explica Hespanha,(1994) ao analisar a Ordem e o Estado no absolutismo Português,

A relação entre Estado e indivíduo chega a aparecer invertida, atribuindo-se ao estado (à qualidade) o poder de mudar o aspecto físico do indivíduo; diz-se, por exemplo, que o estado de escravidão destrói a fisionomia e majestade do homem. (...) Homem que não tenha estado não é pessoa. De fato, há pessoas desprovidas de qualidades juridicamente atendíveis, que não têm qualquer status e, logo, carecem de personalidade. Tal é o caso dos escravos.

Além disso, a análise das entrelinhas dos sermões à luz da História revela-nos uma complexidade imensa na maneira de definir quem era pobre e quem era rico no século XVII. A organização estamental não se resumia às simples definições de nobreza, clero e plebe. A plebe constituía o Terceiro Estado e devedor eterno dos tributos que serviam para sustento dos dois primeiros, tidos como parasitários.

Embora não estivesse inserido em nenhum estamento social, o índio tinha primordial relevância na economia da Colônia. Como elemento de suma importância na formação do Brasil e responsável por toda a produção material, juntamente com os africanos, o índio deve ser analisado com mais profundidade. A tutela o situava na 
incômoda posição de infância da civilização. Com efeito, aquele que ainda está na idade da inocência não era totalmente livre nem podia ser escravo; não possuía autonomia política e também não pagava tributo. Possuía braços para o trabalho e pernas para o transporte, mas $o$ ato de pensar era atribuído ao padre que o cristianizava. Além de sua condição "inferior" frente ao branco, o índio sempre foi alvo de inumeráveis disputas entre missionários e colonos, o que provocava em toda a terra constante instabilidade.

$\mathrm{Se}$ o Novo Mundo contava com essa "classe social intermediária", composta por nativos cristianizados, o que torna mais complexas as dinâmicas de produção e posse, no Reino, apesar da aparente ordem social, constata-se, no Sermão de Santo Antônio, que Vieira demonstra particular preocupação com a configuração dos estamentos, principalmente em função do desequilíbrio entre as classes parasitárias e a tributária. $O$ autor procura definir os três estados e questiona o fato de os dois primeiros não pagarem impostos. Segundo o jesuíta,

Não sejam os remédios particulares, sejam universais; não carreguem os tributos somente sobre uns, carreguem sobre todos. Não se trate de salgar só um gênero de gente. ${ }^{6}$

Como grande analista político e social de sua época, Vieira conhece as fragilidades do Reino de Portugal naquele momento e tenta fazer com que seu público reflita sobre a essência da situação,

\footnotetext{
${ }^{6}$ Sermão de Santo Antônio: p. 323.
} 
insistindo para que todos colaborem com a restauração do Reino, visto que "se se repartir o peso com igualdade de justiça, todos o levarão com igualdade de ânimo"7 .

Todavia, lamenta o autor que a igualdade, objeto de persuasão na retórica cristã, desapareça quando aporta nas docas da racionalidade, visto que "as mesmas igualdades do Céu, em chegando à terra logo se desigualam". Apesar disso,

Bom era que nos igualáramos todos: mas como podem igualar extremos que têm a essência na mesma desigualdade? Quem compõe os três estados do Reino é a desigualdade das pessoas. Pois, como se hão de igualar os três estados, se são estados porque são desiguais? ${ }^{8}$

Acerca das estruturas sociais estabelecidas pelo Cristianismo e fundamentadas nas disposições da Lei Natural, Hespanha (op. cit., 1994) esclarece que

Esta idéia de que todos os seres se integram, com igual dignidade, na ordem divina, apesar das hierarquias aí existentes, explica a especialíssima relação entre humildade e dignidade que domina o pensamento social e político da Europa medieval e moderna. O humilde deve ser mantido na posição subordinada e de tutela que the corresponde, designadamente na ordem e governo políticos. Mas a sua aparente insignificância esconde uma dignidade igual à do

\footnotetext{
${ }^{7}$ Idem: p. 325.

${ }^{8}$ Idem, ibidem.
} 
poderoso. Por isso, o duro tratamento discriminatório no plano social é acompanhado de uma profunda solicitude no plano espiritual. $^{9}$

Com efeito, entende-se por que a pobreza e a misericórdia caminham sempre juntas nos escritos de Vieira. Indissociavelmente, esse binômio compunha o cerne das sociedades católicas e, por conseguinte, de Portugal. Tal fato não pode ser analisado com os olhos e as idéias do século XXI, mas pode servir como base para maior compreensão das estruturas sociais da atualidade, a fim de fornecer meios para atenuar o grande abismo que há hoje entre pobres e ricos. Contudo, não se pode esquecer que, no século XVII, mormente no mundo ibérico, havia a tendência de retorno ao medievalismo, o que enrijecia ainda mais a composição das estruturas sociais. Em face disso, encontramos Vieira com sérios problemas a resolver em Portugal e domínios: a falência dos cofres da Coroa comprometia seriamente o processo de restauração que se tentava por meio da distribuição dos tributos.

A proposta de Vieira é tão incomum para a época, que provoca reação adversa nos estados privilegiados. Segundo ele,

Se os três estados do Reino, atendendo suas preeminências, são desiguais, atendam a nossas conveniências, e não $o$ sejam. Deixem de ser o que são, para serem o que é necessário, e iguale a necessidade os que desigualou a

\footnotetext{
${ }^{9}$ Cultura Jurídica Europeia: p. 80.
} 
fortuna. (...) O Estado Eclesiástico deixe de ser o que é por imunidade, e anime-se a assistir com o que não deve. $O$ Estado da Nobreza deixe de ser o que é por privilégios, e alente-se a concorrer com o que não usa. O Estado do Povo deixe de ser o que é por possibilidade, e esforce-se a contribuir com o que pode: e desta maneira deixando de ser cada um o que foi, alcançarão todos juntos a ser o que devem: sendo essa concorde união dos três elementos eficaz conservadora do quarto. ${ }^{10}$

Seu discurso atinge o clímax quando traz à tona as revelações concernentes às origens da fortuna do clero e da nobreza. As palavras do autor condenam a impassibilidade do clero diante da necessidade do Rei, quando deveria estar atento a quem sempre esteve disposto a socorrer os templos e conventos. Logo, "bem é que restituam os templos aos Reis necessitados. Isto é o que deve fazer o Estado Eclesiástico de Portugal e, em primeiro lugar, os primeiros dele".

A nobreza também não escapa à acidez do jesuíta e sofre um ataque contundente:

A primeira razão é, porque as comendas e rendas da Coroa, os fidalgos deste Reino são os que as logram e lograram

\footnotetext{
${ }^{10}$ Sermão de Santo Antônio: p. 326.
} 
sempre; e é justo que os que se sustentam dos bens da Coroa não faltem à mesma Coroa com seus próprios bens. ${ }^{11}$

$\mathrm{Na}$ verdade, os privilégios conquistados pela clerezia e pela nobreza não são censurados pelo autor porquanto, segundo a organização social da época, essas prerrogativas eram justas. Mas o que Vieira questiona e argumenta é a necessidade de os dois estados privilegiados disponibilizarem suas riquezas adquiridas da Coroa para ajudarem a restauração da própria Coroa.

O que, na verdade, sugere o autor é que os grupos privilegiados cedam parte de suas prerrogativas a fim de auxiliar na reestruturação do poder em Portugal. Todavia, se havia em Portugal estrutura social mais bem definida, o que simplifica para Vieira a análise e a perspectiva de solução, no Novo Mundo a complexidade das situações que encontramos torna o desenho da sociedade setecentista de difícil esboço: havia clero e nobreza, porém o Terceiro Estado era uma extensa colcha de tiras disformes e desiguais, de quase impossível definição: trabalhadores braçais brancos, índios cristianizados e negros alforriados. Além de tudo, existia também entre os moradores dessas terras a ambição da nobreza e, apesar das inúmeras dificuldades, todos queriam garimpar, a qualquer custo, algum título de nobreza. Segundo Nizza da Silva (2005), nem sempre o poder econômico estava vinculado à nobreza ou sua escassez estava vinculada à pobreza. Havia aqui comerciantes possuidores de considerável cabedal financeiro que

\footnotetext{
${ }^{11}$ Sermão de Santo Antônio: p. 331.
} 
jamais poderiam alcançar o estado da nobreza em virtude de seus defeitos de origem. Por outro lado, indivíduos falidos poderiam conseguir facilmente esses títulos e privilégios caso comprovassem, diante da Mesa de Consciência e Casos e do Conselho Ultramarino, sua limpeza de sangue. Dessa maneira, é importante observar que tais prerrogativas, em todas as épocas, podiam ser alcançadas por quaisquer pessoas desde que comprovassem pureza de origem e relativo cabedal financeiro, ao menos para gerir as despesas de um processo dessa natureza. Mas o certo é que o estado de nobreza era desejo comum a qualquer indivíduo daquela época. A verdade é que não havia na terra um indivíduo sequer, mestiço que fosse, que não sonhasse com um dourado título de nobreza.

Para se ter uma ideia, em épocas de guerra, como a que ocorreu no Brasil contra os holandeses, muitos indivíduos com "graves defeitos de qualidade" alcançaram mercê do Rei e foram agraciados com títulos de nobreza ou fidalguia. Exemplo dessa prática foi visto com o índio potiguar Antônio Felipe Camarão que, em 1638, recebeu do Rei "uma comenda que tinha vagado. E ainda uma cadeia de ouro de 2.000 reales com uma medalha do Rer". ${ }^{12}$ Todavia, se tais benesses ocorriam em tempos de combate, quando qualquer indivíduo podia comprovar facilmente os serviços prestados à Coroa, em dias de paz surgia uma infinidade de restrições para se alcançar qualquer título de nobreza. Não é de se estranhar que tantas mercês tivessem sido distribuídas durante o domínio de

\footnotetext{
${ }^{12}$ Nizza da Silva, Ser nobre na Colônia: p. 107.
} 
Castela. Eram tempos difíceis, porém favoráveis àqueles que pretendiam algum título.

As maiores dificuldades da Mesa da Consciência e Ordens em reconhecer o merecimento de um indivíduo, na Europa, residiam em sua genealogia, já que a limpeza de sangue era quesito primordial. Logo, judeus, mouros ou mestiços de qualquer natureza dificilmente tornavam-se nobres. No Brasil, além dos impedimentos existentes em Portugal havia também aqueles, bem peculiares à terra, relativos à miscigenação com gentio da terra ou negro africano. Segundo a documentação coeva, esses eram defeitos muito graves e dificilmente permitiam aos requerentes a tão almejada licença. Há raros exemplos, como o de Domingos Rodrigues Carneiro, negro guerreiro que lutou contra os holandeses e que pertencia ao terço de gente negra de que fora mestre de campo Henrique Dias. Ele foi agraciado pelo rei D. Pedro II, em 1688, com o Hábito de Aviz e a tença de $12 \$ 000$ réis. Porém, se o rei podia deferir o pedido e liberálo dos defeitos de qualidade, os deputados da Mesa de Consciência argumentaram contrariamente, lembrando que o próprio Henrique Dias não passara nos exames da Mesa, por ser pessoa infecta em todos os sentidos, "não parecendo justo que em pessoa tão indigna na estimação das gentes como a de um negro se veja o hábito de São Bento de Avis". ${ }^{13}$

Os títulos concedidos pelo Rei não conferiam a seus portadores simplesmente o reconhecimento na sociedade, mas uma

\footnotetext{
${ }^{13}$ Nizza da Silva, op. cit., p. 118.
} 
série de privilégios que iam desde a isenção de tributos, a concessão de terras, até a pensão pecuniária permanente e hereditária.

Percebe-se, a partir de índices coletados em fontes primárias, a quase absoluta ausência de "homens de cor" nesses processos, o que nos dá uma pista sobre quem já formava o grande bolsão de pobreza no Brasil do século XVII, quando muitos negros e mestiços já conheciam o caminho da liberdade por meio das cartas de alforria. Isso não significa que também não houvesse brancos desvalidos, porém, diante das exigências da Mesa de Consciência e da dificuldade de acesso a um processo dessa natureza, mormente pelo dispêndio necessário, fica claro que, em raríssimas oportunidades, um negro ou um mestiço conseguia esse privilégio, visto que há raros registros de mestiços senhores de terras e possuidores de cabedal econômico. Apesar da forte ausência desses indivíduos nos processos de títulos, é fácil provar por documentos e escritos históricos que a grande maioria da população brasileira, na época, já era composta por mamelucos e mulatos.

Vemos, então, que a pobreza no Brasil de Vieira já estava intimamente ligada à questão étnica. Entendamos, porém, porque, no Planalto de São Paulo de Piratininga, surgiu a chamada nobreza da terra. Ora, conhecedores das dificuldades impostas pela Mesa, os tropeiros, bandeirantes e preadores paulistas sabiam que sua miscigenação Ihes traria constrangimentos e, assim, raramente procuravam títulos de nobreza. Todavia, compunham uma nova espécie de fidalguia baseada no poder econômico e na posse de escravos. Predominantemente índios, além de representarem a 
principal base de produção, escravos demonstravam distinção e poder aos seus possuidores, pois permitiam ao seus donos 0 privilégio de não executarem trabalho mecânico. Assim,

Na Capitania de São Vicente, depois de São Paulo, as principais funções de governança eram desempenhadas por aqueles que dispunham de maior número de índios e que, por isso mesmo, maior produção agrícola podiam arrancar de suas terras dadas em sesmarias. ${ }^{14}$

Quando um homem, branco ou mestiço, conseguia área para cultivo e colocava nela meia dúzia de escravos, tinha, ainda que fosse pobre, muitas possibilidades de mobilidade social, adquiria respeito e podia sentar-se à roda dos homens bons do Planalto. Ademais, se fosse cristão velho, branco e possuísse escravos, apresentava todas as condições de se tornar nobre e receber mercê do Rei. Na dinâmica das concessões de títulos, o que se observa na esfera dos privilégios é a perpetuação da posição de quem já possuía poder econômico.

O arremedo de nobreza que se configurou no Planalto de Piratininga seguia o curso da nobreza oficial. Os senhores de escravos conquistavam postos na administração, mantendo, assim,

\footnotetext{
${ }^{14}$ Nizza da Silva, p. 134. A autora cita a observação de Pedro Taques, segundo a qual Amador Bueno da Ribeira teve "grande tratamento e opulência por dominar debaixo de sua administração muitos centos de índios". Com toda essa mão-de-obra à sua disposição, Amador Bueno acumulou considerável cabedal econômico, que the valeu os títulos de Provedor da Fazenda, Capitão-mor e governador da Capitania. Além disso, facilitou ao filho Domingos da Silva Bueno a conquista do Hábito de Cavaleiro Professo da Ordem de Cristo por mercê de D. João V. Todavia, para isso, teve de comprovar limpeza de sangue.
} 
as possibilidades de poder político e econômico. Tal ocorreu a Sebastião Leme do Prado, sertanista paulista, a quem o Rei concedeu "ser guarda-mor de toda a sua conquista (as Minas Novas de Araçuaí) e dois ofícios (escrivão da ouvidoria e tabelião)". ${ }^{15}$

Observações mais atentas revelam que também havia no Brasil brancos pobres que podiam enriquecer facilmente, porém dificilmente seriam nobres. É o caso de artesãos, ferreiros, sapateiros, cristãos novos, senhores de terras com baixo cabedal e poucos escravos. Já os mestiços pobres, com defeitos de qualidade pela sua condição étnica e antepassados braçais, jamais viriam a ser nobres, assim como os negros alforriados e os indígenas livres, marcados eternamente pela condição da miséria. Vimos assim, por esse breve esboço da escala social no Brasil, que a base da riqueza da terra estava, sem dúvida, centrada nos braços escravos, fossem eles africanos ou indígenas.

Se, nesse contexto social, o retrato do índio parece-nos definido, no contexto econômico o nativo representava a maior motivação para os conflitos - como já dito anteriormente - entre jesuítas e outras ordens; entre jesuítas e colonos, jesuítas e a Coroa, principalmente no momento de se desbravar o extremo norte da Colônia. A situação está clara no Sermão da Epifania, quando Vieira recorre à autoridade da rainha regente, levando ao seu conhecimento a situação crítica que vivera no Maranhão, do qual havia sido expulso pelos colonos. Todavia, o que há nas entrelinhas do discurso de Vieira é a pobreza daqueles que se instalaram nas

\footnotetext{
${ }^{15}$ Anais do Arquivo do Estado da Bahia (apud Nizza da Silva, op. cit., p. 94).
} 
matas virgens da Colônia e deviam tirar dela o sustento. Quem sabe, entendendo, em certos momentos, a delicadeza da situação, o jesuíta arriscava algumas propostas para resgates de índios e se convencia de que não havia como remediar a necessidades dos colonos sem os braços indígenas, pelo fato de "serem os índios 0 único remédio e sustento dos moradores, que sem eles pereceriam". Dessa maneira, a mão-de-obra indígena, em maior ou menor quantidade, tornou-se um importante fator de definição de quem seria pobre e de quem seria rico entre os brancos, naquela região. Certamente, um colono com maior número de braços a seu dispor teria condições de produzir muito mais e em pouco tempo acumularia grande cabedal de bens; entraria na dinâmica das concessões das mercês e logo se tornaria um nobre. O caminho era claro e visível, todavia escarpado.

A demanda pela mão-de-obra nativa tornou-se cada dia mais feroz. Com efeito, tanto colonos quanto autoridades enviadas pelo Rei perderam a noção das necessidades mais primitivas dos índios, tais como a alimentação. O nativo foi drasticamente despojado de sua já "tênue" humanidade:

"Não Ihes dão tempo para lavrarem suas roças, com que eles, seus filhos e suas mulheres padecem; enfim, em tudo são tratados como escravos, não tendo a liberdade mais que no nome, pondo-Ihes nas aldeias por capitães alguns mamelucos ou homens de semelhante condição, que são os executores 
destas injustiças, com que os tristes índios estão hoje quase acabados e consumidos."

Era nesse "moinho de gastar gente" que se esgotava rapidamente a possibilidade de enriquecimento para muitos colonos. Apesar de esses senhores pouco atentarem para a humanidade dos nativos, o índio era gente e, como tal, possuía seus limites, fronteiras de vigor que se estreitavam em virtude da precariedade da existência que the era oferecida.

Embora Vieira construa uma eloquente defesa da liberdade do índio, deve-se observar que esse se constituía no único meio de sobrevivência e enriquecimento dos colonos. De nada adiantava o discurso inflamado do inaciano, quando os próprios governadores, que deviam ser protetores das leis da Igreja e de Sua Majestade, usufruíam livre e corruptamente do trabalho indígena, como vemos abaixo:

"O remédio que isto tem, e não há outro, é mandar V.M. que nenhum governador ou capitão-mor possa lavrar tabaco nem outro gênero, nem por si nem por interposta pessoa, nem ocupem nem repartam os índios, senão quando fosse para as fortificações ou outras coisas do serviço de V.M."17

O que não se pode esquecer é que Vieira conhecia muito bem toda a gradação social do Reino de Portugal e seus domínios. Circulava

\footnotetext{
${ }^{16}$ Carta ao Rei D. João IV, em 20 de maio de 1653, p. 88.

${ }^{17}$ Carta ao Rei D. João IV, em 20 de maio de 1653, p. 88.
} 
entre as várias categorias de gentes e sabia mensurar a necessidade de atender a todas elas segundo os padrões do Cristianismo, em que acreditava. Em seu pensamento, o rico podia sê-lo, desde que fosse misericordioso. O pobre, como parte primordial daquela estrutura, devia ser suprido em suas carências e protegido pelos poderosos, alimentado suficientemente a fim de manter o vigor para o trabalho.

O mundo de Vieira, embora parecesse organizado e bem definido, em alguns momentos revela o mais absoluto caos. Isso se vê ao reforçar ele, ainda, sua arriscada proposta de tributação para a nobreza e para o clero. Segundo ele, muito do aparato religioso de Portugal e de seus domínios foi bondosamente construído pela misericórdia e benevolência da Coroa:

"Porque, se atentamente se lerem as nossas crônicas, apenas se acharão templos, ou mosteiros em todo Portugal, que os Reis portugueses com seu piedoso zelo ou não fundassem totalmente, ou não dotassem de grossas rendas, ou não enriquecessem com preciosíssimas dádivas. Impossível coisa fora deter-me em matéria tão larga e inútil, e tão sabida. Concorram, pois, as Igrejas a socorrer a seus Fundadores, a sustentar a quem as enriqueceu e a oferecer parte de suas rendas às mãos de cuja realeza receberam todas. Mais é isso justiça que liberalidade; mais é obrigação que benevolência; mais é restituição que dádiva." 
É admirável constatar a coragem e a força discursiva do jesuíta quando tenta abalar os fundamentos de uma ordem alicerçada nos privilégios e na riqueza, tal como era o estado clerical.

A teologia católica, baseada na simplicidade das origens do Cristianismo, sempre difundiu a ideia de pobreza como uma virtude que pode ser sublimada pela recompensa no porvir. Entretanto, no século XVII, enquanto essa ideia prevalecia no âmbito da Teologia, a prática mostrava outra tendência. Diante da possibilidade de enriquecimento e conquista de notabilidade, tanto em Portugal quanto em seus domínios, ninguém mais queria continuar pobre, e a procura por títulos de nobreza, visando a benefícios econômicos, tornou-se acirrada, fato bastante evidente no Sermão da Terceira Quarta-Feira da Quaresma, de 1670. Segundo Vieira, esse é o sermão dos pretendentes, das pessoas que prestaram serviços à Coroa e se julgavam dignos dos títulos oferecidos pelo rei. $\mathrm{O}$ autor recomenda ao soberano que seja direto e objetivo e diga não aos pretendentes, mesmo que essa negativa represente perigo a sua popularidade. Nesse caso, o rei pode ficar livre dos dissabores "aplicando o não também a si, e primeiro a si que aos súditos" ( $p$. 259).

Historicamente pode-se constatar que, após a restauração da Coroa portuguesa, a distribuição de títulos de nobreza e de privilégios a fidalgos atingiu o auge. Nas entrelinhas do sermão em questão, lê-se que a volumosa demanda de processos causava certos transtornos ao soberano. Um taxativo não por parte do rei representaria a cessação do "tumulto e inundação dos 
requerimentos, que verdadeiramente o afogam". Logo, Vieira recomenda ao Rei que

"Seja o príncipe justo, e tão constantemente justo, que por nenhum outro motivo nem respeito dê a ninguém senão o que merecer e Ihe for devido; e logo os vassalos se não atreverão a pretender as sem razões e exorbitâncias que vemos, e se benzerão de pedir como de tentação."18

Ainda no concernente à corrida pela busca de títulos, no Sermão da Terceira Dominga do Advento, Vieira trata da questão de maneira mais incisiva. À sombra da explicação sobre o pretendente e o pretendido, o autor argumenta ao Rei que os súditos leais e fiéis são os pretendidos e não os pretendentes. Com efeito, quando os homens são pretendidos e os cargos pretendentes, a república alcança melhor sucesso:

"Cristo, supremo Monarca e exemplar de todo o bom governo, não queria no seu Reino homens pretendentes, nem ofícios pretendidos: homens pretendidos e ofícios pretendentes, sim. (...) Estes são os que só podem compor, conservar e estabelecer um Reino que houver de durar para sempre, como o de Cristo." $" 19$

Por outro lado, o perigo da distribuição de cargos e títulos residia no ônus que tal prática poderia a vir representar para a

\footnotetext{
${ }^{18}$ Sermão da Terceira Quarta-Feira da Quaresma, p. 258.

${ }^{19}$ Sermão da Terceira Dominga do Advento, p. 56.
} 
"economia" de todo o Reino. Vieira aponta no já analisado Sermão de Santo Antônio, os problemas de uma sociedade onde todos querem ser nobres. $E$, assim, isentos de impostos, inflam as despesas da Coroa e enfraquecem o poder de reação contra os inimigos. Ora, Portugal vivia momento crítico contra as forças de Castela e precisava de cabedal econômico. Não podia mais suportar o crescimento vertiginoso das duas classes parasitárias, o clero e a nobreza. O remédio sugerido pelo jesuíta era que clerezia e nobreza também tivessem obrigações tributárias, pois o Terceiro Estado, somente, não conseguia mais suprir, sozinho, as carências do Reino.

Percebe-se agora o porquê de tanta gente porfiar um título de nobreza. Sem dúvida, a principal motivação estava, certamente, na isenção dos tributos, impostos que contribuíam pesadamente para o empobrecimento dos integrantes do Terceiro Estado.

A fim de restringir ao máximo a concessão de títulos, a Mesa de Consciência forja a cada dia exigências que impeçam a titulação de pessoas de "baixa qualidade" ou com defeitos de qualidade. As licenças, em tempos de guerra facilmente avalizadas pelo rei, praticamente desaparecem. Assim, muitos pretendentes, que esperavam ser favorecidos pelas benesses do rei, veem suas possibilidades ruírem. 


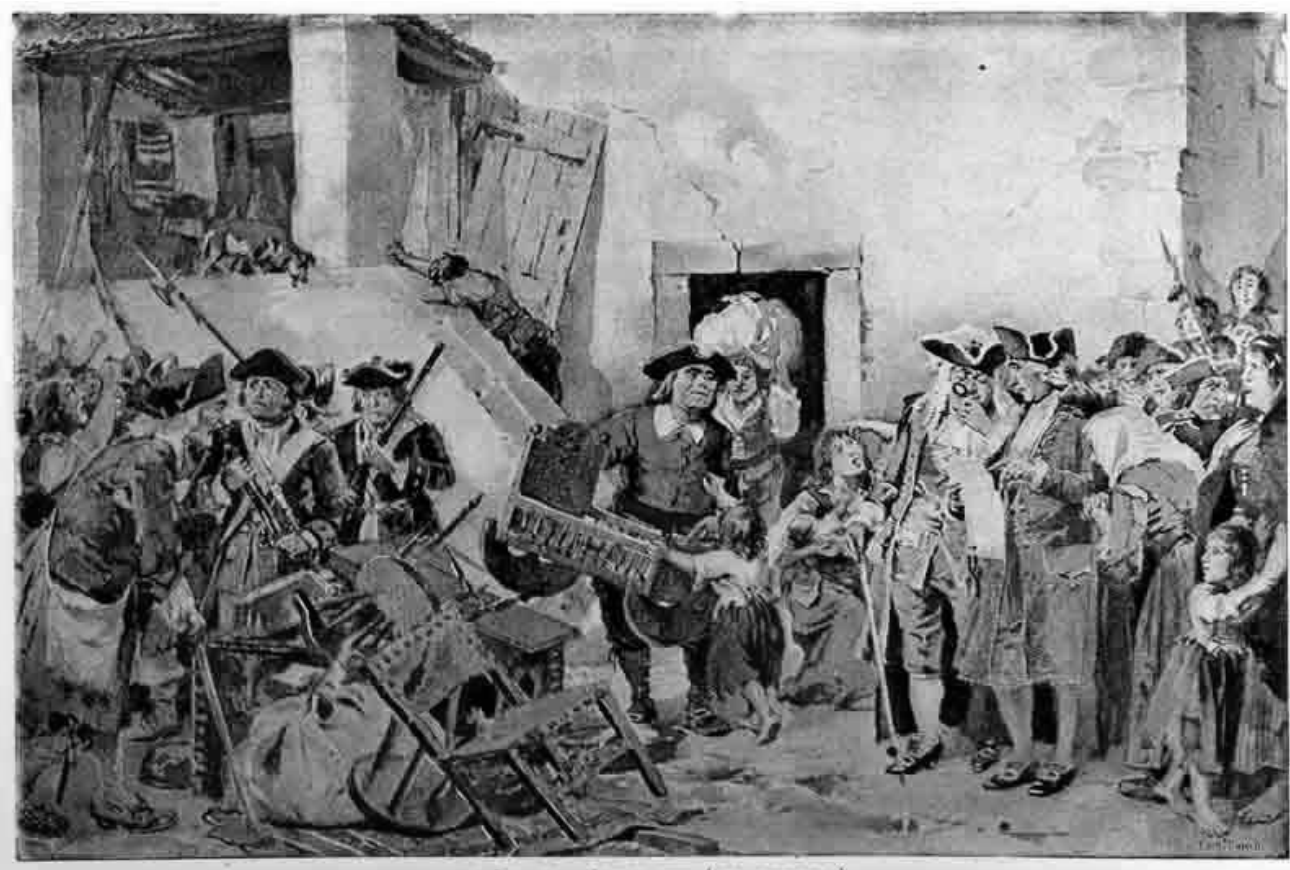

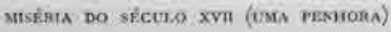

Figura 1. Os cobradores dos tributos do Rei eram implacáveis. Na ausência de ouro ou dinheiro, qualquer objeto de valor era levado em penhora, provocando trauma econômico nas famílias e lançando-as em situação de vergonha e pobreza.

Parece bastante complexo para qualquer estudioso de literatura desvendar as estruturas sociais relacionadas a tempos e espaços tão remotos como estes de Portugal recém-restaurado e do Brasil Colônia no século XVII, principalmente quando se nota que a configuração da pobreza e da riqueza rompe a esfera imanente e mergulha na transcendência das idéias daquele mundo, regidas pelo dogmatismo da Igreja que tinha a pretensão de retornar ao poderio medieval. Descobrir e entender a organização social daquele momento é imergir nos palácios, nos engenhos, nos colégios, nas aldeias, nas igrejas, nas câmaras, nos acampamentos dos tropeiros e nos redutos mais reclusos das famílias. Trabalhando dessa forma 
e buscando as peculiaridades das gentes portuguesas foi que descobrimos outro importante elemento que está intimamente ligado à pobreza: a bastardia.

Fato muito comum na cultura lusa, a bastardia se observa no Brasil desde os primeiros momentos de seu povoamento, principalmente a partir de 1530, com a repartição do seu território em Capitanias Hereditárias. Os jesuítas, no momento de sua chegada, em 1549, já percebem a existência de grande população de mamelucos. Ao aportar na Bahia, em 1553, Anchieta, em uma de suas primeiras cartas, escreve que a terra está "inçada de mamelucos". ${ }^{20}$ Assim, derramados em copiosa quantidade pela extensa terra de Santa Cruz, pouquíssimos desses mamelucos eram aceitos como filhos de seus pais brancos. Já formavam já um bolsão de gente sem qualidade e sem confiança.

Além da questão da existência dos mamelucos ou de toda a sorte de mestiços, que nos remete a pistas sobre a formação da pobreza no Brasil, partimos da análise desse assunto em registros sobre a condição da mulher nessa época. Diante do notável trabalho de Priore (2008), notamos como a bastardia, além de ser um traço fortemente peculiar ao povo português, vitimava mulheres de todas as etnias, inclusive brancas. Tal fato influenciou decisivamente a formação social do Brasil naquele tempo e manteve-se, até hoje, como um dos mais profundos pilares da estrutura cultural brasileira. Nessa condição de abandono,

\footnotetext{
${ }^{20}$ PEREIRA, Rosemeire França de Assis Rodrigues. A Literatura de José de Anchieta e a Gênese da Educação Brasileira, p. 80 (dissertação de mestrado). A autora orienta-se pela Carta de Piratininga de 1554, escrita por Anchieta um ano após sua chegada.
} 
"Essas mulheres, empurradas para o empobrecimento e a fragilidade social no quadro já adverso da economia de exportação, justificavam aos olhos da Igreja metropolitana a necessidade de implantar um processo de adestramento entre as populações femininas."21

Há na tramitação oficial dos documentos no Brasil atual a tendência de se considerar apenas a maternidade, visto que a paternidade nem sempre é conhecida. Um exemplo disso são os registros de eleitores, nos quais constam apenas os nomes das mães. Nota-se que essa prática colonial resiste até nossos dias, arraigada e sem data para desaparecer. Com efeito,

"A presença de tantos fogos com chefia feminina e a consequente valorização da matrifocalidade explicam-se, em parte, quando reconstituídas as histórias de seduções físicas seguidas de abandono e de esquecimento."22

Como afirma o próprio Vieira, no que concerne à igualdade entre homens e mulheres, esta só é, na verdade, possível no âmbito espiritual. A vala da humilhação sempre foi o lugar da maioria das mulheres naquele século e não há como negar o distúrbio social que causava a condição de uma mulher que se tornava arrimo de família numa estrutura patriarcal. Sabemos que, em todas as culturas, há sempre a diferenciação dos gêneros. Porém, ao analisarmos as culturas judaico-cristãs percebemos as dificuldades impostas às

\footnotetext{
${ }^{21}$ Priore, Mary del, "Mulheres seduzidas e mães abandonadas" in Ao Sul do Corpo, p. 68. 22 Ibidem, p. 68.
} 
mulheres por essas sociedades. E não é incomum encontrarmos registros de famílias mendicantes, desde a Idade Média, regidas por mulheres. Quem sabe abandonadas por seus parceiros ou, talvez, pretendendo apenas a maior eficácia de sua condição de pedintes, essas mães usavam sempre "as criancinhas, que serviam com particular eficácia aos seus propósitos, pois inspiram os mais vivos sentimentos de compaixão e misericórdia". ${ }^{23}$

São relatados os constrangimentos enfrentados por certos requerentes de títulos de nobreza, que não conheciam seus pais, possuindo em sua história apenas a referência à mãe. Caso bastante peculiar e que mereceu a atenção de Nizza da Silva foi o de Fernandes Vieira (século XVII) que, na época em que pedia mercê do Rei, foi denunciado por baixa condição social:

"Veio este senhor a esta terra e capitania de Pernambuco da Ilha da Madeira, donde é natural e filho de uma mulata rameira, a quem chamam de Benfeitinha, e de um homem que Ihe dão por pai, que foi ali degradado a título de ladrão."24

Nota-se que a questão da bastardia abrangia as diversas etnias existentes no Brasil e servia como impedimento importante para a reprovação diante do Conselho Ultramarino e da Mesa e, em não poucos casos, o requerente era denunciado por alguém de sua convivência. No processo de Fernandes Vieira, além da questão da

\footnotetext{
${ }^{23}$ GEREMEK, Bronislaw. Idade Média: A utilidade dos pobres in A Piedade e a ForcaHistória da Miséria e da Caridade na Europa, p. 63.

${ }^{24}$ Apud Maria Beatriz Nizza da Silva, Ser nobre na Colônia, p. 88.
} 
bastardia e da suposta origem "impura", pesavam ainda sobre si sua amizade com um judeu e a prática de trabalho mecânico. Com efeito, o denunciante desse infeliz mestiço não queria mesmo vê-lo a participar da nobreza.

Apesar de ser comum, qualquer indivíduo sabia que a bastardia acarretava dúvidas sobre sua educação e origem, mesmo porque tal condição, por si só, já representava defeito de origem. Assim, a bastardia aparece como trauma social de muitos portugueses e brasileiros no século de Vieira, surgindo, assim, como um sério impedimento para ascensão social e representando para os indivíduos eterna situação de humilhação e, na maioria dos casos, de pobreza que, como um ciclo vicioso, era transmitida de geração a geração.

Relevantes trabalhos têm sido desenvolvidos nos últimos tempos para tratar da questão do abandono de crianças. Um deles, o de Valverde (1994), discorre sobre o abandono de crianças no País Basco, nos séculos XVI e XVII, analisando a desordem social que a bastardia causava naqueles burgos, onde crianças de outras localidades eram abandonadas pelos pais:

"At La Inclusa, in Madrid, as many as 55.420 were taken off between 1586 and 1700. Many of them had been brought from neighbouring villages and abandoned in the streets of the city." 25

\footnotetext{
${ }^{25}$ Valverde, Lola, Poor Women and Children in the European Past, p. 53
} 
Se, para os filhos bastardos, a situação era sempre desfavorável, para as mulheres que produziam esses rebentos sem ter maridos a marginalidade era certa. Não são poucos os registros de mulheres que recorreram às autoridades porque foram enganadas e abandonadas prenhes. No Brasil, as de maior conhecimento jurídico, geralmente brancas e filhas de pais respeitáveis, recorriam à justiça a fim de obrigar o consorte a cumprir o contrato de casamento, o que nem sempre era alcançado. Em muitos casos, os próprios familiares das jovens que incorriam nessa situação eram seus mais cruéis algozes. A fim de defender a honra das famílias, as filhas eram expulsas de casa ou internadas em conventos, contra sua vontade, no caso das de maiores posses. Porém, não obstante essas exceções, a maioria esmagadora dessas mulheres caía, mesmo, no abismo da difamação e da prostituição e, consequentemente, na pobreza crônica e hereditária. 


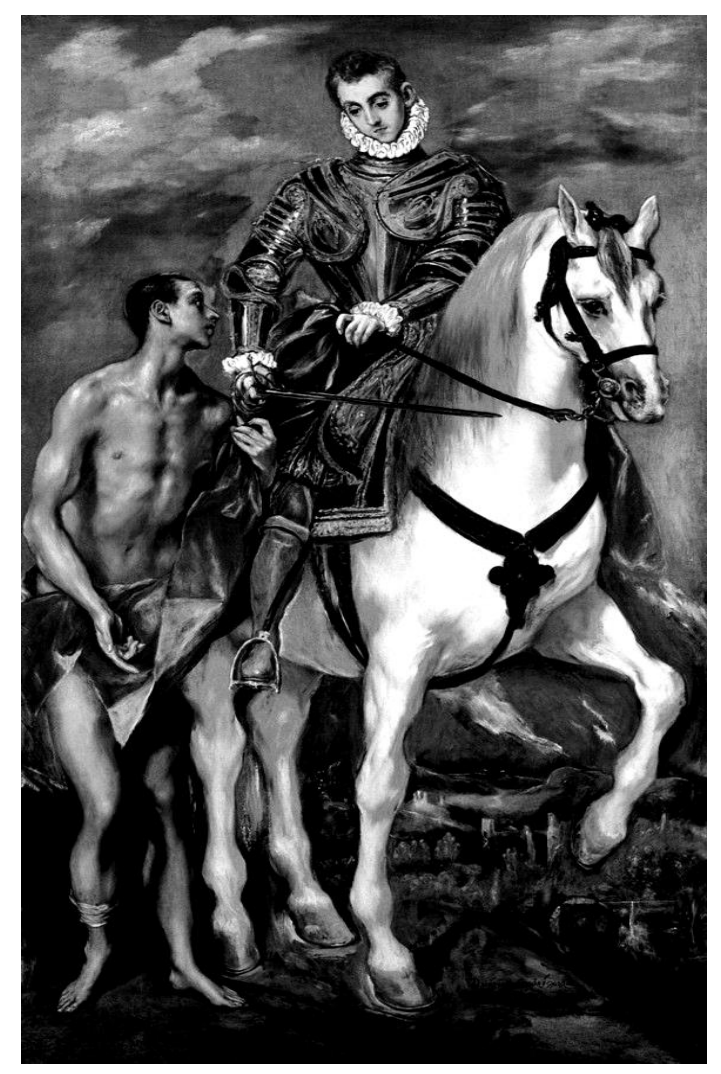

\section{Figura 2 - São Martinho e o Pobre, de El Greco}

Longe de conduzir a humanidade à igualdade, a misericórdia, segundo os preceitos contrarreformistas, aumentava ainda mais as diferenças entre quem fazia e quem recebia a caridade.

Assim, a desigualdade referida por Vieira em seus sermões não se verificava apenas na escala social organizada e estabelecida, mas também na escala horizontal, onde eram tidas em menor valia as mulheres e as crianças. Aqui se configuram os bastidores de uma sociedade onde a pobreza era virtude espiritual e desgraça no plano material. 


\section{CAPÍTULO II}

\section{O SERMÃO DAS OBRAS DE MISERICÓRDIA: O POBRE COMO O PRÓPRIO CRISTO}

Escrito em 1647 e pregado na capela do hospital Real, em Lisboa, o Sermão das Obras de Misericórdia condensa toda a essência do pensamento católico a respeito da pobreza. Ao homenagear a Irmandade das Obras De Misericórdia, Vieira permitenos analisar a dinâmica de uma sociedade tradicionalmente cristã em analogia com seu discurso.

Não obstante a essência de o sermão situar-se na surpreendente revelação da posição do pobre no contexto (espiritual) vigente, é importante observar que a primeira intenção do texto é de apologia à atuação da Irmandade. A bem-aventurança do pobre não teria sentido sem a bem-aventurança da misericórdia. Para isso, Vieira usa como epígrafe de seu texto o trecho bíblico de Mateus, capitulo V, "beati pauperes; beati misericordes".

Entre as inúmeras confrarias que se estabeleceram no decorrer de toda a trajetória da Igreja, as das obras de misericórdia prevaleceram, resistiram $\mathrm{e}$, no século $\mathrm{XVI}$, foram, inclusive, assimiladas pelo Protestantismo, por terem fundamento bíblico na epístola de São Tiago. O campo de atuação dessas sociedades abrangia abertura de hospitais, orfanatos, albergues, visitas a 
prisões e distribuição de alimentos. Normalmente estas instituições eram mantidas por meio de doações dos ricos, incentivados pelo clero. Previam, enfim, a recompensa aos seus participantes.

Em Portugal, particularmente, a Irmandade das Obras de Misericórdia era dirigida pela rainha. $\mathrm{Na}$ época em que Vieira prega o Sermão em análise, D. Luísa de Gusmão, esposa de D. João IV - o duque de Bragança - tornar-se-ia, a partir de 1656, Rainha Regente de Portugal, sendo encarregada das ações da Irmandade, a qual tinha como principal projeto a manutenção e a ampliação do hospital real. Essa idéia está refletida no mundo atual, mormente naqueles países de cultura ibérica, por meio das Santas Casas de Misericórdia. Embora muitos teóricos concebam a atuação dessas confrarias como pretexto para controle das classes subalternas, como Michel de Foucault, no universo cristão elas são legítimas e necessárias, pois, colaboram para a permanência e o fortalecimento de uma estrutura social estabelecida.

A história da Irmandade das Obras de Misericórdia em Portugal tem seu início no final do século $\mathrm{XV}$, pela extrema dedicação da Rainha D. Leonor, esposa de D. João II. Após a morte do Rei, a Rainha aderiu, em seus trinta anos de viuvez, a uma concepção de vida que valorizava o recolhimento, a solidão e a contemplação. Muito dada a leituras hagiográficas e das próprias Escrituras, D. Leonor adotou a caridade como seu fundamento de vida, tanto material quanto espiritual. Nesse sentido, a fusão das esferas material e metafísica na existência da eminente rainha tornou-se tão evidente e manifesta que todo o restante de sua vida 
ocorreu em função da estruturação das irmandades de misericórdia em Portugal. Assim

"foi sempre amorosa mãy dos pobres, e com elles gastou a mayor parte das suas rendas. Deu principio à celeberrima Irmandade da Misericórdia de Lisboa, donde dilatou a todo o Reyno, em grande benefício dos naturaes, e universal admiração dos Estrangeiros. "26

Para isso, D. Leonor contou com o envolvimento de grande parte da nobreza que, com seus atos de caridade, angariava não somente a simpatia da real senhora, mas, principalmente, fazia a ostentação da bondade, tão importante no Catolicismo, haja vista que o bom nobre precisa também ser bom cristão. Ao seguirmos 0 fluxo da história religiosa e cultural de Portugal, fica possível explicar o discurso proferido por Vieira, aproximadamente duzentos anos após a morte de D. Leonor.

É importante observar que a concepção de misericórdia adotada por D. Leonor vai em direção a nossa concepção mais ampla de piedade. A caridade em D. Leonor rompeu os limites do óbolo oferecido ao pobre e alcançou esferas mais amplas. A misericórdia exercida pela Rainha manifestou-se em sua dedicação a objetos sagrados, na publicação de livros sacros antigos - como foi o caso do Bosco Deleitoso - e também no investimento nas produções literárias e artísticas no Reino português: D. Leonor foi a

\footnotetext{
${ }^{26}$ Santa Maria, Pe. Francisco de, Anno Histórico, Diário Portuguez. Lisboa, Oficina de Domingos Gonçalves, 1744, p. 353, apud Sousa, p.55.
} 
grande patrocinadora da obra de Gil Vicente e praticou o mecenato renascentista durante toda a sua vida.

Além dessa caridade refinada, a misericórdia de D. Leonor também funcionava como um poderoso tentáculo do poder. Não era raro a nobre senhora socorrer fidalgos em desespero, interceder politicamente por nobres falidos e arrecadar dos cofres reinóis fundos para conventos e mosteiros. Apesar dessa caridade abrangente, a perífrase de "mãe dos pobres" foi a que mais representou a imagem de D. Leonor, como se constata na documentação coeva supracitada. Essa perífrase remete-nos a uma concepção de caridade antes não entendida, a caridade ao próximo geográfica e socialmente situado, o que rendeu à nobre senhora 0 título de "mater omnium".

A reinvenção da caridade, segundo D. Leonor, possibilita outro entendimento acerca do pobre, que se revela no discurso de Vieira. A partir das Escrituras, Vieira redesenha a figura do pobre no cenário português, considerando, principalmente, o que é desprovido de bens materiais e, de certa forma, vítima de uma estrutura social imutável ou, ainda, presa passiva da predestinação e do providencialismo.

Ao expor em análise as razões e atitudes de D. Leonor, percebe-se que, além da posição espiritual atingida mediante a prática da misericórdia, por meio das esmolas distribuídas a pobres e nobres necessitados, a soberana sentia uma grande satisfação e era notório seu prazer em brincar de ser Deus, pois a caridade possui também uma faceta nebulosa e transforma em reféns os 
beneficiados por ela. Segundo o Cristianismo, ninguém contraria seu benfeitor; antes o protege e apoia. Ao discorrermos acerca da caridade praticada por $\mathrm{D}$. Leonor, lembramos as afirmações de Buarque de Holanda sobre o homem cordial, que se resume

"Na padronização das formas exteriores da cordialidade, que não precisam ser legítimas para se manifestarem (...). Armado dessa máscara, o indivíduo consegue manter sua supremacia ante o social. E, efetivamente, a polidez implica uma presença contínua e soberana do indivíduo."27

Certamente esse fenômeno, que se estabelece e se reforça no perpassar dos séculos na cultura brasileira, tem suas raízes na Europa e traja a roupagem da bondade e da caridade, assim como a rainha portuguesa que se apropriava dos bens da Coroa para ostentar bondade aos desvalidos. Entretanto, não podemos esquecer que não havia ainda, no Antigo Regime, distinção entre o público e o privado, e toda a concepção de caridade da época será determinada por isso. Dessa maneira explica-se, nos documentos oficiais do Brasil colônia, a constante referência aos homens bons da terra. Não se tem a intenção de questionar a legitimidade dos atos de D. Leonor, porém, nota-se como os índices religiosos do Portugal antigo prevalecem, muitas vezes, intocáveis nas culturas gestadas pelos lusos, criando a possibilidade de distanciamento social e a

\footnotetext{
${ }^{27}$ Holanda, Sérgio Buarque de, Raízes do Brasil, p. 147.
} 
perpetuação do indivíduo em sua posição, historicamente bem definida.

Esta exposição fez-se necessária a fim de que entendamos o discurso de Vieira sobre a Irmandade em questão. Pensando no tempo e no espaço que envolviam o jesuíta, nota-se o valor e a importância que a prática da misericórdia possuía na sociedade portuguesa seiscentista. Está claro que, como tradição que remonta aos tempos medievais, com a versão cristã originada na Igreja primitiva, a caridade sempre foi qualidade e dever do rico. Como ação própria de um estrato social privilegiado, a misericórdia referenda e perpetua uma estrutura social totalmente legitimada pela religião. Deve haver sempre, nas sociedades cristãs, os ricos que doam e os pobres que recebem. Não foram os pobres, como poderia haver caridade? "Pobres sempre tereis entre vós", disse Jesus. Situação estabelecida assim faz-nos lembrar e reinterpretar a Parábola do Bom Samaritano: um homem que descia de Jerusalém para Samaria, cai nas mãos dos salteadores que o roubam, surramno e o abandonam meio morto. O Levita passa de largo, o Sacerdote passa de largo, porém, o Bom Samaritano cura suas feridas, montao em sua cavalgadura e leva-o até uma hospedaria. Lá, oferece dinheiro ao dono da estalagem para que esse cuide daquele homem. Ora, o Bom Samaritano, como figura representativa da caridade descrita por Cristo, totalmente isenta de interesses, redesenha-se na sociedade portuguesa por meio das Irmandades de Misericórdia. É flagrante a releitura dessa parábola nas práticas de $D$. Leonor quando manda construir o Hospital das Caldas para atendimento dos 
pobres. Com efeito, para isso, chegou a desfazer-se de algumas jóias suas. ${ }^{28}$ Todavia, não se pode esquecer de que o homem agredido, na parábola acima citada, não era o pobre clássico (o miserável) porquanto possuía bens que foram levados pelos salteadores. Por outro lado, o benfeitor também não participava da elite da sociedade judaica, mas da escória na qual se tornou o povo de Samaria no decorrer da história dos judeus. Não obstante a conveniente interpretação das Escrituras, as obras de misericórdia na sociedade portuguesa caminham com muita força e tornam-se argumento e ferramenta política para a contenção das massas, mesmo durante a União lbérica.

Em defesa do governo dos Filipes em Portugal, Serrão não hesita em citar a construção de "17 misericórdias e de 30 hospitais (...), a cobertura assistencial das zonas mais urbanizadas, aproveitando um terço da população do Reino"29. Considerando-se o grande fluxo de pessoas nas regiões portuárias, entende-se por que era prioridade do poder público construir hospitais nas regiões mais urbanizadas. Geralmente, as misericórdias eram erigidas próximas aos hospitais ou anexas a esses e ofereciam outras modalidades de assistência que não podiam ser realizadas naqueles. Uma vez que as misericórdias e os hospitais agregavam notabilidade aos reis no

\footnotetext{
${ }^{28}$ Op. cit., p. 55. O costume dos hospitais de caldas prevaleceu por muito tempo em Portugal e seus domínios. Nessas instituições, os enfermos eram submetidos a banhos termais, quase sempre em águas minerais, tidas como milagrosas para a cura de doenças internas e externas, bem como de feridas, aleijões e uma infinidade de doenças de pele. Particularmente no Brasil, até finais do século XIX e início do XX, esse tipo de tratamento era bastante procurado. Poços de Caldas, nas Minas Gerais, foi grande exemplo de onde se usava tal tipo de terapia.

${ }^{29}$ SERRÃO, Joaquim Veríssimo. O Tempo dos Filipes em Portugal e no Brasil (15801688), p. 175.
} 
reinado dos Filipes, calcula-se a importância dessas instituições para o povo português, pois se revela, assim, a caridade como obrigação de qualquer monarca cristão.

Como importantes elementos do universo católico-cristão, a pobreza e a misericórdia compõem o discurso de Vieira numa única linha de pensamento e confluem para o mesmo fim, de maneira que esse fabuloso binômio não permite qualquer dicotomia. O Sermão das Obras de Misericórdia, como todos os escritos do jesuíta, não pode ser analisado fora do contexto político-social no qual se desenvolveu o gênio do autor. Ao considerar que se trata de um escrito pós-restauração e contrarreformista, comporta evidências de um período em que o autor realizava importante papel diplomático junto à nobreza portuguesa, influenciando suas atividades e decisões tanto na luta pela recolocação de Portugal no cenário comercial do mundo quanto no combate à heresia protestante. Tendo sido pregado na capela real, o Sermão das Obras de Misericórdia apresenta uma linguagem propícia e absolutamente condizente com o momento e com o público receptor que, podendo ser híbrido, como observa Hansen (2008), mescla a linguagem, que atende tanto ao discreto quanto ao vulgar com a mesma eficácia de interpretação:

(...) "Pois, as semelhanças e diferenças agudas que seu juízo estabelece entre os conceitos distantes encenam para seu público as operações de seu juízo que, orientado pela luz natural, acha reflexo adequado dela nos signos das coisas de 
que trata, para iluminar as mentes de seus destinatários discretos e vulgares."30

Vieira inicia o Sermão analisando o pobre em duas categorias distintas: o pobre que assim se fez por escolha, como é o caso de São Francisco de Assis, que deixou a riqueza e o conforto de sua família e se fez mendigo; e o pobre miserável, aquele que, por infortúnio ou destinação histórica, implora o pão nas escadarias dos templos e nas praças. Nessa categorização fica evidente que

“(...) começando pela pobreza, este nome tão mal avaliado entre os homens tem duas significações. Há pobreza, diz Santo Agostinho, que é virtude, e pobreza que é miséria. A pobreza que é virtude é a pobreza voluntária com que se desprezam todas as coisas do mundo. A pobreza que é miséria é a pobreza forçada, com que se carece dessas mesmas coisas, e se padece a falta de todas.

Essa concepção de pobreza configura-se na Idade Média e alcança o século XVII preservada pela ideologia católico-cristã que vê no pobre oportunidade para a salvação do rico. Michel de Foucault analisa essa "pobreza útil" e afirma que, em especial na Contrarreforma, a caridade tinha três objetivos: religioso (conversão e moralização), econômico (socorro e incitação ao trabalho) e

\footnotetext{
${ }^{30}$ Hansen, João Adolfo. Sistemas doutrinários da representação nas obras de Antonio Vieira. In Vieira, vida e palavras, Edições Loyola, São Paulo, 2008.

${ }^{31}$ Sermão das Obras de Misericórdia, p. 78.
} 
político (luta contra o descontentamento ou agitação). ${ }^{32}$ Uma vez que a Contrarreforma, gestada no Concílio de Trento, compele os fiéis à busca e retomada do cristianismo medieval, as investigações de Foucault revestem-se de sentido. Mesmo assim, é preciso situar Vieira no pensamento de seu tempo pois, não obstante a lentidão com que as idéias da Europa chegavam ao Brasil, considera-se que o autor dos Sermões viveu a maior parte de sua vida circulando pelas cortes européias e já estava absolutamente inserido no contexto reformador, em plena ação contra a heresia e a favor da reconstrução e fortalecimento da Igreja. Prova desse pensamento é o magnífico Sermão pelo Bom Sucesso das Armas de Portugal contra as da Holanda, escrito em 1640 por ocasião da invasão holandesa na Bahia, onde deixa clara a sua defesa ferrenha da religião católica e o combate implacável à religião reformada. Há aqui um questionamento direto a Deus acerca da verdadeira fé e uma grande preocupação em descobrir de que lado está Deus:

“(...) pois é possível, Senhor, que hão de ver vossas permissões argumentos contra vossa Fé? É possível que se hão de ocasionar de nossos castigos blasfêmias contra vosso nome? Que diga o Herege (o que treme de o pronunciar a língua), que diga o Herege que Deus está Holandês?'33

Consideremos a procedência das observações de Foucault, salvaguardando sua modernidade. Analisemos Vieira em seu contexto, absolutamente teológico. E é nessa perspectiva que

\footnotetext{
${ }^{32}$ In Vigiar e Punir, p.175

${ }^{33}$ Antonio Vieira, Sermões. Organização de Alcir Pécora, tomo I, p. 449.
} 
emergimos no Sermão, não esquecendo que as fronteiras entre a política e a religião, no século XVII, eram inexistentes.

Tendo como epígrafe Beati pauperes: beati misericordes, como já dito acima, Vieira situa tanto a pobreza quanto a misericórdia num mesmo espaço, definitivamente unidas e dependentes, beatificadas no mesmo discurso sob uma única concepção. Essa conciliação de valores extremos é muito comum em todo o universo cristão e, particularmente, no contrarreformado, quando se acentuam as forças próprias do Catolicismo como representações manifestas de uma luta constante contra a heresia e as diferenças que esta poderia causar na fé havia muito estabelecida. Assim como a invenção do bem e do mal fortalece a concepção espiritual maniqueísta, que nos alcançou por meio de Santo Agostinho, a pobreza e a misericórdia resistem inquestionáveis como partes integrantes de uma sociedade que acabou de recuperar sua autonomia diante do mundo e pode escolher ser presa apenas da religião, que é seu fundamento cultural. Para se ter idéia do teor religioso do povo português, em 1645, D. João IV convoca todas as cortes a Lisboa e emite o voto de "que a imagem de Nossa Senhora de Vila Viçosa fosse jurada como padroeira de Portugal'34. Como sabido, Vila Viçosa era o reduto dos Braganças e, assim, revela-se mais uma vez a grande influência da religião sobre as dinastias lusas.

Voltando à análise do Sermão: a primeira pobreza é voluntária, a segunda é predestinada. Dessa maneira,

\footnotetext{
${ }^{34}$ Serrão, Joaquim Veríssimo. O tempo dos Filipes em Portugal e no Brasil (1580-1668), p.41.
} 
"os pobres da pobreza que é virtude são bem-aventurados porque hão de ver Deus; os pobres da pobreza que é miséria são bem-aventurados porque neles está Deus."’35

Ao construirmos uma escala de ascendência semântica dos tipos de pobreza analisados pelo jesuíta, está claro que a pobreza que é miséria situa-se no topo do cosmo espiritual porque Deus está no pobre miserável, bem como está na hóstia. Cria-se, então, uma nova representação eucarística baseada nos Evangelhos. Aqui se localiza o cerne do Sermão e de toda a concepção vieirense acerca da pobreza. Porém, há necessidade de dissecar a dinâmica desse pensamento e sua construção em toda a Cristandade, pois há nas Escrituras referências divergentes acerca da pobreza: no Antigo Testamento era inconcebível ao povo judeu admitir situações de miséria e privações, visto que, como povo escolhido, a prosperidade devia ser inerente a eles. Basta observar a maneira como deixaram o Egito, onde foram escravos por mais de quatrocentos anos. $O$ êxodo só foi possível em virtude dos recursos que eles portaram deserto afora. Tão sólido era o tesouro judaico que, com as jóias das mulheres, construíram eles a Arca da Aliança, que simbolizava seu principal canal de comunicação com o sobrenatural. ${ }^{36}$

Apesar de a concepção de pobreza bem-aventurada estar ligada ao ministério de Cristo, nota-se que seu discurso dirigido aos judeus comporta referências ao poder material como representações

\footnotetext{
${ }^{35}$ Sermão das Obras de Misericórdia, p. 78.

${ }^{36}$ Êxodo 25, 16: "E cobri-la-ás de ouro puro, por dentro e por fora a cobrirás: e farás sobre ela uma coroa de ouro e fundirás para ela quatro argolas de ouro".
} 
da presença de Javé. Assim, é interessante observar nas parábolas que o filho pródigo era rico, o mancebo de qualidade também era rico. Isso para entender que Cristo atendia a todos, independentemente de serem pobres ou ricos. Por que não falar do centurião, de Zaqueu, de Jairo, da mulher que tinha o fluxo de sangue, todos ricos que recorreram a Cristo e foram muito bem acolhidos por ele? Não se sabe ao certo quando a pobreza transformou-se em bem-aventurança dentro do Cristianismo, porém há indícios nos escritos de Tiago que nos remetem ao que pode ser a raiz dessa concepção, tais como:

Ouvi meus amados irmãos. Porventura, não escolheu Deus aos pobres deste mundo para serem ricos na fé e herdeiros do Reino que prometeu aos que amam $?^{37}$

Ao assimilar o pensamento de Tiago em seu discurso, Vieira afirma que o óbolo lançado aos pobres acertaria Cristo, pois este estava encoberto sob as espécies daqueles:

"Do mesmo modo, quando São Martinho deu a metade da capa ao pobre, não via mais que o pobre, mas ali estava Cristo. "38 Em suma, "a fé é aperfeiçoada pelas obras". 39

\footnotetext{
${ }^{37}$ Tiago 2:5. O apóstolo condena a acepção de pessoas. Historicamente sabe-se que a Igreja de Jerusalém, a Primitiva, após ter vivido momentos de intensa prosperidade, experimentava, então, as privações que acometem muitos dos irmãos, pois, sob o domínio de Roma, os habitantes de Jerusalém são duramente taxados e os cristãos, perseguidos e expropriados de seus bens. Assim, Tiago orienta aos que ainda retêm algum poder material a ajudar aos que vivem em situação de miséria.

38 Idem: p. 83.

39 Tiago 2:22.
} 
O discurso de Vieira também nos obriga a uma investigação por camadas. Na contextualização que nomeia ora Cristo, ora Deus, contamos com o vasto conhecimento da Trindade, dominado pelo autor. Posto isso, o leitor desavisado deve ter em mente Cristo/Deus/Espírito Santo como indispensável triângulo (Trindade) no qual se embasa o Cristianismo. Por isso, Cristo e Deus para Vieira representam uma unidade perfeita.

Voltando ao Sermão, imagina-se que se reuniriam, então, os doentes e desvalidos de Lisboa naquele hospital, pois eles seriam o objeto de possibilidade para o exercício da misericórdia. Todos eles traziam em si o Cristo transfuso. ${ }^{40}$ Podem agora os ricos ostentar a fé e a caridade "no teatro da piedade cristã (em que a mesma piedade junta em corpo de congregação é a principal e melhor parte do mesmo teatro)." N1 Não seria vã a atitude "pois, sabei que em todos esses pobres está o mesmo Cristo que adoramos na Hóstia", prossegue Vieira. A sacralização do pobre e de sua condição de miséria resumem-se num dado cultural importante nas sociedades cristãs e se transforma em paradigma poderoso no decorrer de todo a nossa pesquisa. Com efeito, nenhum elemento, dentro do copioso universo das representações do Catolicismo, adquiriu tão grande privilégio quanto esse que foi dispensado ao pobre. A hóstia é o próprio corpo sagrado de Cristo, pela idéia da transubstanciação; e o pobre é magistralmente, por Vieira, elevado ao nível da hóstia, tornando-se Cristo também. É importante observar como o jogo

\footnotetext{
${ }^{40}$ No Sermão das Obras de Misericórdia, Vieira orienta-se pela análise de São Pedro Crisólogo, que nomeia a fusão do homem com Cristo de transefusão (p. 81).

${ }^{41}$ Idem: p. 78.
} 
discursivo de Vieira nos conduz gradativamente à comprovação dessa majestosa transfusão: primeiro, "menos era ou seria se Cristo se contentasse só com assistir e estar no pobre"; segundo, conforme afirma S. Pedro Crisólogo, do qual Vieira toma emprestado o discurso, "o mesmo Cristo se fez e quis ser o mesmo pobre". Assim,

"O assistir e o estar no pobre pode-se entender conservandose a diferença das pessoas entre a de Cristo e a do pobre. Mas o ser não se pode verificar senão passando a diferença a constituir identidade, e sendo o pobre o mesmo Cristo, e o mesmo Cristo o pobre: Ut ipse sit pauper." ${ }^{\text {"42 }}$

O discurso de Vieira serpenteia de maneira a valorizar a caridade ao pobre e, principalmente, ao pobre miserável, adotando, assim, uma concepção mística mais dogmática que aquela realizada por D. Leonor. Nesse contexto, a misericórdia é o passaporte para o céu, à disposição daqueles que querem se purificar e se aproximar de Cristo por intermédio da caridade. Além disso,

"A misericórdia humilha Deus e sublima o homem; humilha Deus porque na esmola o pobre o sujeita a receber do homem; e sublima o homem porque na esmola o levanta a dar a Deus."43

\footnotetext{
${ }^{42}$ Sermão das Obras de Misericórdia, p. 80. Localizam-se as citações das linhas acima na mesma página.

${ }^{43}$ Idem, p. 80
} 
Ora, imaginemos Deus, encoberto nas espécies do pobre, recebendo a esmola das mãos do homem. Dessa maneira, o homem torna-se sublime, porque é a criação que doa ao Criador. Por sua vez, o Criador diminuto e humilhado reconhece a misericórdia como o único dispositivo que o faz prostrar-se diante de sua criação. Nesse sentido, a misericórdia é realmente uma das armas mais poderosas para a contenção e o conformismo das massas, pois há duas coisas que o homem precisa para a sobrevivência de sua alma: poder material e poder espiritual. Para o pobre, segundo Vieira, restou a segunda opção. O pobre é a evidência da existência de Deus, que só se manifesta no ato da misericórdia. Entende-se, então, por que a misericórdia não tem como função resgatar o miserável de sua condição. Basta afagá-lo; ele já é bem aventurado - beati misericordes.

Ao recordar que o Cristianismo nasceu pela crença na presença de Deus na terra na pessoa de Cristo, os adeptos dessa fé, constantemente, buscam provas ou vestígios dessa visita celestial aos homens, fato que justifica a insistência de Vieira em mostrar Cristo no pobre e ratificar suas palavras ao proferir que Cristo não está "no pobre de qualquer modo, senão (...) nele permanentemente". ${ }^{44}$ Por outro lado, considerando a idéia da união mística entre Deus e o rei, tão corrente nos reinos absolutistas católicos, e diferentemente, a união que ocorre entre Cristo e o pobre supera todas as expectativas da busca de Deus na terra: o pobre é o

\footnotetext{
${ }^{44}$ Sermão das Obras de Misericórdia, p.80.
} 
próprio Cristo enquanto o rei era apenas o representante daquele. Mesmo assim, Pécora (2001) observa que

"Antonio Vieira não pretende afirmar o pobre como o frágil da hierarquia social, mas, muito diferentemente disso e de acordo com as doutrinas neotomistas, afirmá-lo enquanto necessidade que percorre e estreita o conjunto do corpo político."A5

Isso significa que, conforme o pensamento vigente no século XVII, e no bojo do estado absolutista, o pobre representa nada menos que um dos elementos essenciais que compõem a esfera social e o corpo político, intimamente ligado à divindade. Voltando à análise da união mística do Rei, principal figura na hierarquia monárquica, há de se entender por que o pobre também precisa estar inserido nessa esfera mística, que sempre envolveu, por completo, todas as dinastias portuguesas. Reforça ainda Pécora que "enquanto organismo hierárquico, o corpo social necessita estar integrado dos pés (pobres) à cabeça (Rei)". ${ }^{46}$ Assim, não há dúvida de que o pobre para Vieira é um simples componente das representações sociais seiscentistas e, teologicamente, a Cristandade não pode prescindir dele.

É importante observar que, além da simples definição de pobreza que se obtém à primeira leitura, o Sermão nos remete a muitas reflexões. A mais importante, quem sabe, é a que nos leva a não esquecer que, não obstante a manifestação de sua convicção, Vieira está inserido no mundo barroco, que é largamente povoado

\footnotetext{
${ }^{45}$ Pécora, Alcir. Teatro do Sacramento, p.108.

46 Ibidem.
} 
por figuras e representações para a composição do discurso. Partindo desse pressuposto, deve-se entender o que é e o que não é representação no Sermão. Segundo o discurso do próprio autor, o Sermão não reside fora da esfera artística e, assim, deve ser ouvido, entendido e tratado. Malgrado, ele é um dos índices de suscitação da fé e não escapa do "grande e formoso teatro da piedade cristã,47 que nada mais é que a tentativa de materialização de atitudes espirituais como a misericórdia.

No processo de sacralização da pobreza, Vieira faz algumas observações dignas de análise. "A pobreza que é miséria, à qual nem se prometem os bens do Céu, nem ela possui os da terra, antes padece a falta de todos", induze-nos a imaginar o que realmente nos faz dignos do Céu - a esmola, certamente. Instrumento do qual o pobre não dispõe e, por conseguinte, não teria como chegar ao Paraíso. Numa cultura onde se vincula a salvação à prática da misericórdia, de que maneira aquele que não tem como realizar misericórdia alcança a salvação? Qual será o dispositivo usado para sua redenção? Como já dito, o pobre acolhe Cristo sob suas espécies; logo, o céu já lhe pertence. Contrariando a pregação de Cristo, que oferece a salvação a qualquer pessoa, independente de sua condição social, física, política, racial, a salvação, segundo Vieira, condiciona-se pela prática da piedade aos pobres.

Se nos reportarmos às questões históricas, vemos que a prática da caridade e a materialização da misericórdia podem, a certo tempo, gerar situações de comodismo nas classes subalternas,

\footnotetext{
${ }^{47}$ Sermão das Obras de Misericórdia, p. 78.
} 
que forçam os reis e os governos a repensarem a distribuição de esmolas em determinadas regiões da Europa, já no final do século XVI. Caso particular é o que aconteceu em Veneza, após sucessivas epidemias, causadas, talvez, pelo constante circular de pobres e pedintes nas ruas, entre o penúltimo decênio do século $X V I$ e 0 terceiro decênio do século XVII. Como medida paliativa, promulgouse nessa cidade a "Lei sobre os Pobres" segundo a qual é necessário

"Assegurar assistência aos pobres, socorrer os doentes, dar pão aos famintos, mas não permitir que os que pudessem fazer serviço de seu corpo vivessem em ociosidade. ${ }^{\text {,48 }}$

Conforme Geremek (1987), surge, nesse momento, uma moderna doutrina para a caridade. Nessa época proíbe-se a entrada de mendicantes forasteiros e aos pobres locais é oferecido um tratamento disciplinar: detectam-se aqueles que são hábeis para 0 trabalho, os quais são entregues à marinha e ocupados como tripulação nas embarcações. As mulheres e as crianças eram recomendadas aos artesãos, aos quais serviam como aprendizes e auxiliares. Em conjunto com essas iniciativas, ordena-se também que as paróquias e irmandades organizem a distribuição de víveres aos pobres que realmente não tinham como trabalhar e garantir sua sobrevivência. Nota-se que o século XVI também trouxe uma nova maneira de pensar sobre a organização social que havia perdurado

\footnotetext{
${ }^{48}$ GEMEREK, Bronislaw. A Piedade e a Forca: p. 164.
} 
por toda a Idade Média. A caridade começa a se institucionalizar como assistência organizada e normatizada segundo os cânones temporais, embora mantivesse ainda a essência religiosa.

De volta ao Sermão, outro ponto para refletir é a revelação de que "para se conservar na mesma miséria, (o pobre) há de pedir e depender da vontade alheia"49. Se analisarmos racionalmente a afirmação do autor, entendemos a ineficácia da misericórdia como ferramenta de recuperação social, visto que conservará o pobre na sua condição e fará dele integrante de um estamento social eternamente dependente. Ao analisar a prática de distribuição de esmolas na Alta Idade Média, Gemerek (1986) cunha a expressão pobreza pensionada, quando revela o acolhimento dos hospitais eclesiásticos aos pobres estáveis. Confirma também que

"antes de se converter em lugar de reclusão para os mendigos, o hospital desempenhou a função de hospício, proporcionando-lhes abrigo temporário e organizando distribuições de esmolas.

É importante observar que o fato de os pobres serem arregimentados para o trabalho, no século $\mathrm{XVI}$, não provava a intenção dos governos de tirá-los daquela condição, mesmo porque o que ganhavam era suficiente apenas para sua sobrevivência como pobres. Então, assim como a misericórdia em forma de esmolas condiciona e perpetua o pobre no seu reduto social, a organização

\footnotetext{
${ }^{49}$ Sermão das Obras de Misericórdia, p. 78

${ }^{50}$ GEREMEK, Bronislaw. A Piedade e a Forca, p. 57
} 
do trabalho para o pobre torna-se a reinvenção da caridade $\mathrm{e}$ fortalece a existência do baixo estamento nas sociedades modernas. Não obstante a inclusão do miserável no processo produtivo das grandes cidades da época, essa iniciativa do poder público não o resgatava da miséria porquanto o seu jornal situava-se abaixo do necessário para a sobrevivência.

O perigo dessa nova maneira de lidar com a pobreza e o pobre, após o Renascimento, é que o pobre passou a ser visto como fonte de desordem e condutor de epidemias. Daí, as políticas de repressão aos pobres e pedintes em toda a Europa intensificam-se e transformam $\mathrm{o}$ ato de mendigar em crime que deve ser combatido. Apesar de ser imprescindível na sociedade moderna, o pobre deve aceitar que sua inserção depende do trabalho que ele oferece, senão será caçado e castigado na mesma categoria dos vagabundos.

O pobre a que se refere Vieira aparece-nos como um ser teatralizado e, por conseguinte, irreal. $\mathrm{Na}$ verdade, o pobre do Sermão das Obras de Misericórdia é o pobre digno, predestinadamente salvo porque é a imagem e figura do próprio Cristo. Por outro lado, o pobre real é um ser repugnante, que desarticula a ordem social e deve ser banido das ruas e ocupado em favor do poder econômico.

Um mergulho mais profundo no Sermão revela a verdadeira diretriz seguida por Vieira na construção de seu discurso que, embora à primeira vista pareça intrincado e complexo, segue as normas estabelecidas pela Companhia de Jesus em concordância com os acordos firmados durante o Concílio de Trento. Segundo 
Hansen (2008), "Vieira pensa a verdade e a verossimilhança do que afirma em suas obras". Assim, seus Sermões não podem ser avaliados como meros aparatos estéticos, mas justificam toda a tentativa de reconciliação do Catolicismo com a Europa, mormente aquela perdida para a heresia. Na tentativa de transpor o tempo e aproximar analogicamente fatos distantes e díspares, o autor transmite aos que o ouvem a revelação de coisas ocultas, mas que, pela aproximação e sua construção figurativa, tornam-se compreensíveis a qualquer pessoa, tanto discreta quanto vulgar. Embora pregado na Capela do Hospital de Lisboa, e quem sabe, tenha sido ouvido por um público seleto, o Sermão da Obras de Misericórdia foi elaborado estrategicamente para alcançar até o mais inculto dos ouvintes, aliás, como todos os sermões vieirenses. Da mesma forma que a elaboração do discurso possibilita 0 entendimento e desperta no rico a necessidade de praticar a caridade, o pobre também facilmente identifica-se com aquele representado no discurso do autor. Armadilhas dogmáticas ou não, engana-se aquele que imagina o pobre do Sermão como real. $\mathrm{Na}$ verdade, ele é apenas impressão da conceituação de Vieira a partir da analogia bíblica construída por outrem, Cristo, que viveu à semelhança do pobre, e que, servindo-se de sua autoridade diante dos discípulos, recriou em si a imagem do miserável por meio de impressões discursivas.

Identificam-se no Sermão das Obras de Misericórdia todos os índices de predicação e transmissão da palavra, tendo como sustentação a representação dos fatos históricos figurados nos 
acontecimentos presentes como base de uma profecia autorizada. Nesse sentido, ao contrário do que se pensava no primeiro momento, o Sermão das Obras de Misericórdia traduz uma realidade escatológica, como não poderia deixar de ser, visto que se fundamenta no último sermão de Cristo antes de sua crucificação, o Sermão da Montanha. Grosso modo, pode-se dizer que Vieira sempre viveu seu presente com os olhos no futuro, tanto materialmente quanto espiritualmente. A trajetória de sua vida parecia curta demais para a infinidade de idéias e proposições que formulou em prol do reino e da esperança de fazer Portugal emergir como o Quinto Império.

Entretanto, nada se compara à imagem de Deus despojado de sua grandeza e divindade quando, oculto na substância do pobre, recebe a obra de misericórdia. Salvas as fortes ocorrências discursivas, que representam a alma do fazer de Vieira, existe no texto a tentativa de aproximação do físico com o metafísico, do natural com o sobrenatural. A realização desse artifício confirma a tendência da nova Escolástica, fundamentada no Aristotelismo interpretado segundo as necessidades da lgreja no século $\mathrm{XVI}$, que induz o pregador a emitir signos verbais, no caso do Sermão, que são interpretados como imagens das imagens mentais ou metáforas. ${ }^{51}$

No sentido em que ora entendemos o Sermão das Obras de Misericórdia, a questão da justificação fica implícita na essência do discurso do autor e sua veiculação na máquina cultural, pois, embora

\footnotetext{
${ }^{51}$ HANSEN, João Adolfo. "Sistemas doutrinários da representação nas obras de Antonio Vieira”. In Vieira, vida e palavra. Edições Loyola, São Paulo, 2008.
} 
saibamos que um dos objetivos de Vieira, em seus sermões, era a manutenção do Corpo Místico do Império ordenado e intacto, é notório como a alegoria articulada por discursos anteriores e reforçada pela sua impecável eloquência rompeu as fronteiras do tempo e conquistou lugar cativo no pensamento da nação portuguesa e seus domínios. Assim, a justificação é traduzida por quem leu e a maneira como entendeu.

Entre os infinitos conceitos expostos pelo autor, há o da misericórdia que se antepõe ao sacrifício. Quer dizer, a misericórdia é mais importante que o sacrifício porque, sem ela, todas as outras tentativas de agradar a Deus são anuladas. Essa máxima estabelecida por São Tiago, escritor e participante da Igreja Primitiva, atribui à caridade um valor imprescindível para a salvação. Diferentemente da exposição de Paulo Apóstolo aos Coríntios, onde a caridade é representada pelo verdadeiro amor, conhecido na cultura helênica como ágape (sinonímia das festas fraternas dos gregos), amor em ação, Vieira articula a soberania da misericórdia em consonância com São Tiago, atribuindo à esmola o caráter de instrumento da salvação, porquanto "livra de todo o pecado, ainda que fosse mortal, e não consente que a alma vá para o inferno". 52

Quando se comparam, no discurso de Vieira e nos escritos de Paulo, a significação das palavras misericórdia e caridade, percebese que há uma leve, porém importante, distância entre as duas, considerando-se o contexto. A caridade, segundo Paulo, é o amor em ação, como já foi dito, e pode, muitas vezes, estar além do

\footnotetext{
${ }^{52}$ Sermão das Obras de Misericórdia, p. 95.
} 
óbolo ${ }^{53}$. A caridade, segundo o apóstolo, supera a fronteira de 0 simples dar esmola. Enquanto a misericórdia descrita por Vieira necessita do apêndice das "obras", a misericórdia por si só, etimologicamente, é apenas ter o coração na miséria do próximo. Teologicamente, a caridade se constitui em algo muito mais completo e não pode ser confundido com misericórdia. Outro termo bastante usado na esfera cristã é "compaixão". Talvez este esteja mais próximo da misericórdia por representar a participação de alguém no sofrimento do outro. Se a misericórdia deve ser traduzida em sua essência, refletida na caridade, analisam-se agora as condições para que seu exercício seja possível:

"Fez Cristo menção da comida e bebida, dos que têm fome e sede, do vestido dos nus, da pousada dos peregrinos, da visita aos enfermos e encarcerados, mas não falou uma só palavra na sepultura dos mortos. Pois se as Obras de Misericórdia são sete, e a sétima é sepultar os mortos, por que alega Cristo as outras seis e esta não?"54

Identificam-se as convenções sociais nascidas do pensamento teológico, arraigadas e transformadas em pilares das culturas ibéricas, nomeadamente a lusa. Com efeito, não há referência nas Escrituras às obras de misericórdia. O que há, na verdade, são ações típicas do justo segundo os padrões veterotestamentários e as

\footnotetext{
${ }^{53}$ Coríntios 13:3. Bíblia de Estudo Pentecostal: "E ainda que distribuísse toda minha fortuna para sustento dos pobres e ainda que entregasse meu corpo para ser queimado, se não tivesse caridade, nada disso me aproveitaria".

${ }^{54}$ Sermão das Obras de Misericórdia: p. 91.
} 
exigências neotestamentárias de assistência e apoio ao semelhante. Entretanto, há na doutrina católica, forçosamente, a conta de sete obras de misericórdia, como já dito por Vieira, sendo a última o sepultamento dos mortos, que, segundo o autor, não foi citada por Cristo pelo fato de o morto não padecer qualquer sofrimento, visto que a ordem de Jesus referia-se apenas aos que o padecem. Segundo o jesuíta, a caridade mais autêntica seria aquela oferecida a quem está impassível, porquanto desse não fluem agradecimentos nem preces.

Apesar de as sete Obras de Misericórdia serem tão correntes e ocuparem tanto espaço nos escritos católicos, segundo Vieira, tudo que é feito ainda é pouco, pois se gasta mais suprindo altares que atendendo aos pobres. Para Cristo, naquele último dia "a pública e mais agradecida estimação [...] não há de ser das grandes riquezas com que o servem no sacramento, senão das esmolas", pois maior honra será de quem lhe deu de comer do que a de quem o comeu. ${ }^{55}$

A eloquente intervenção de Vieira chega ao destino há muito pretendido quando o enunciador volta-se para o público presente e questiona:

"E haverá cristão em Lisboa que, vendo e reconhecendo Cristo no pobre faminto, não tire o bocado da boca para o sustentar? Que vendo-o despido, se não dispa para o vestir? Que vendoo encarcerado ou cativo, se não venda para o resgatar? Que vendo-o peregrino e sem abrigo, o não receba não só em sua

\footnotetext{
${ }^{55}$ Sermão das Obras de Misericórdia: p. 94.
} 
casa, mas o não meta dentro no coração e o sirva de joelhos? O que assim faz é cristão: o que assim o não fizer, nem tem cristandade nem fé. "’6

A autoridade de seu discurso, mais uma vez, ultrapassa os limites das meras representações e alcança o lugar real, sua verdadeira magnitude, fundamentada em sua grande erudição e indiscutível conhecimento das dinâmicas doutrinárias. Sugere muito mais que uma apologia à Irmandade homenageada: o tom é canônico e persuasivo da primeira à ultima frase. $O$ objetivo do enunciador é provar a presença de Cristo no pobre e, para isso, lança um desafio cujas armas são as questões acima apresentadas. Certamente nenhum cristão duvidaria do exposto em todo o Sermão, senão negaria sua própria cristandade, principalmente porque "assim como a água apaga o fogo, assim a esmola extingue os pecados" ${ }^{57}$

A institucionalização da bondade por meio das confrarias das Obras de Misericórdia tem sua razão de ser nos benefícios espirituais que confere a seus participantes. Porém, essa transformação em organismo político complexo não se configura na Igreja Primitiva. Havia, sim, o mandamento da caridade e da assistência ao pobre na fala dos apóstolos, mas não havia casas para o fim, pois partiam do pressuposto de que a situação de necessidade de alguns irmãos era passageira ${ }^{58}$. Por isso, é bastante

\footnotetext{
${ }^{56}$ Idem: p. 93

${ }^{57}$ Sermão das Obras de Misericórdia: p. 95.

${ }^{58}$ Carta aos Filipenses: cap. IV. No texto, Paulo deixa clara a situação da Igreja em Jerusalém, que está extremamente necessitada e só os filipenses podem socorrê-la. $O$ próprio apóstolo foi muitas vezes sustentado pelos irmãos de Filipos.
} 
curiosa a maneira como o mundo ocidental, convertido ao Cristianismo, sacramenta o pobre e faz dele peça fundamental numa escala social construída na terra com olhos no céu, para que

"por meio da pobreza de uns e misericórdia de outros, sem embargo de sermos todos pecadores, (Deus) nos franqueasse nesta vida as portas de sua graça, para que achemos abertas na vida eterna as da glória" ${ }^{59}$

Logo, a pobreza se justifica como instrumento importante no percurso da vida espiritual da Cristandade, guardando em si um mandamento e uma promessa nos quais todos, indiscriminadamente, acreditam, praticando a misericórdia com fervorosa convicção de que, ao oferecer seus bens aos pobres, abrirse-ão as portas do paraíso.

\footnotetext{
${ }^{59}$ Sermão das Obras de Misericórdia: p. 96.
} 


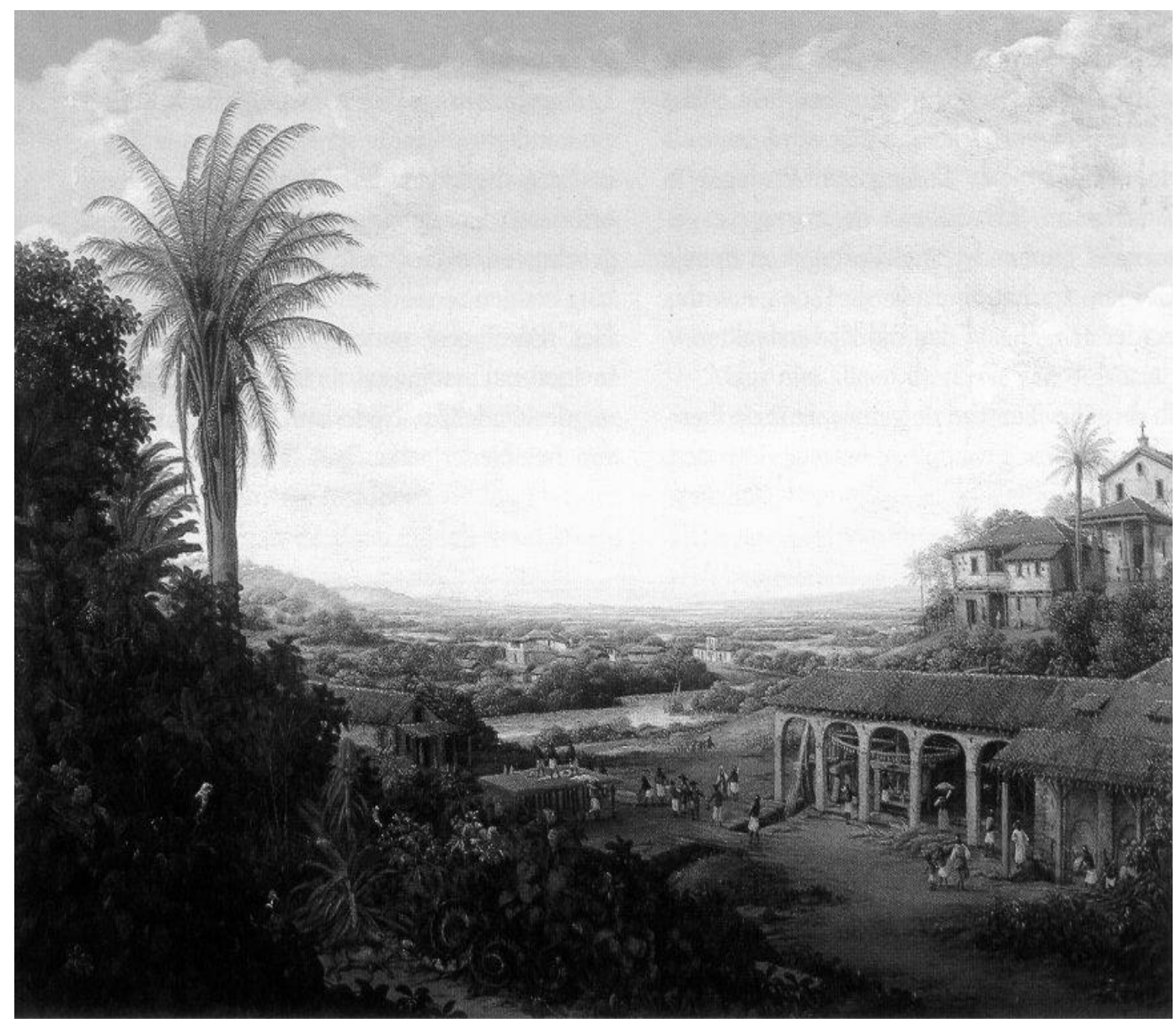

FIGURA 3 - Engenho de Pernambuco (Franz Post)

Os holandeses já estavam, desde 1630, estabelecidos em Pernambuco, onde enriqueciam com o plantio e a exploração da cana-de-açúcar, lá permanecendo até 1654. 


\section{CAPÍTULO III}

\section{O SERMÃO DA VISITAÇÃO DE NOSSA SENHORA A SANTA ISABEL: O POBRE, INSTRUMENTO PARA A OBTENÇÃO DO AUXÍLIO DIVINO, SOLDADO QUE PELEJA POR TODOS NÓS}

O Sermão da Visitação de Nossa Senhora a Santa Isabel foi escrito em 1638, na Bahia, em agradecimento a Deus pela vitória contra a invasão dos holandeses que sitiaram a cidade com o firme propósito de domínio. Este sermão é composto de onze partes e em todas elas evidencia-se o reconhecimento da vitória como ato da providência divina.

A primeira parte do Sermão é uma tentativa de comparar a alegria dos cristãos da Bahia à alegria de Nossa Senhora quando, em visita a Santa Isabel, descobre que será a mãe do Messias. A segunda é expressão da convicção do merecimento da mercê de Deus, apesar das imperfeições dos homens. Na parte seguinte, Vieira expressa a certeza de que o Senhor da Guerra vence todos os gigantes, em analogia à história de Davi. Na quarta parte, o autor menciona algumas guerras dos hebreus contra os pagãos por ocasião da conquista da Terra Prometida. A quinta parte é a confirmação contundente de que, assim como Deus lutou por Sansão, Josué, Gideão e Davi, os portugueses não podem ter

dúvidas de que sua vitória emanou dos braços do Senhor em resposta às suas petições. A partir da sexta parte, Vieira introduz 0 
discurso da gratidão pela vitória, enfatizando a obrigação dos atos de misericórdia. Assim:

"Ditoso e bem-aventurado (diz o profeta Rei) todo aquele que entende e se ocupa servir e remediar os pobres. Não é este o fim e instituto da Santa Irmandade da Misericórdia, como se foram as palavras trasladadas do seu próprio compromisso? Sim. E por que diz o profeta, que são ditosos e bem-aventurados todos os que se exercitam e ocupam em obra tão pia? Segue-se o porquê: In die mala liberabit eum Dominus."

O texto revela que, além das prerrogativas já descritas no Sermão das Obras de Misericórdia aos praticantes da caridade (sendo a principal delas o legado do Reino dos Céus), surge uma nova motivação para se fazer o bem ao pobre: o grande livramento no dia mau. Pois isso aconteceu aos moradores da Bahia. Foram vitoriosos porque eram piedosos e ocupavam seu tempo em "servir e remediar os pobres". Portanto, no dia de perigo, aflição ou aperto não permitirá Deus que sejam entregues ao poder dos inimigos.

Se o sermão de 1646, proferido em Portugal, possuía um tom escatológico que o fazia priorizar a figura do pobre, elevando-o ao nível da hóstia, neste, a misericórdia assume outro contorno: tem características de uma grande fortaleza, um forte espiritual erigido sobre as pedras da benignidade. Nota-se, então, que está arraigada

\footnotetext{
${ }^{60}$ Sermão da Visitação de Nossa Senhora a Santa Isabel: p. 226.
} 
no Brasil a concepção da virtude da beneficência aos pobres, organizada e institucionalizada como poderoso tentáculo da Igreja e da Coroa portuguesa.

Por conseguinte, os portugueses, como Maria, trazem em seu interior a boa nova da chegada de Cristo, que se apresenta em forma de vitória contra a "heresia". Vieira fala em nome da Bahia e tenta traduzir a inexplicável admiração diante de tão grande mercê. Et unde hoc mihi? São as palavras que revelam o êxtase da Bahia, logo na primeira parte do referido sermão. Foram quarenta dias de peleja contra a forte armada holandesa, dias que Vieira comparou aos do dilúvio. Este de água, o da Bahia, de fogos de artilharias e guerra incessante. Porém, o que possibilitou tal vitória?

Unde, donde? Da prudência dos nossos ilustríssimos Generais, e da bem aconselhada dissimulação (mal entendida do vulgo) com que deixaram marchar sem oposição o inimigo até o lugar onde estava entrevista a sua ruína. Unde, donde? Da bizarra resolução dos nossos Mestres de Campo, posto que de três nações diferentes unidos em tomar o governo das armas, em que só o império e obediência delas entre os dois Generais esteve duvidoso. Unde, donde? Do valor dos famosíssimos Capitães e soldados, que antes de haver trincheiras, eles $o$ foram a peito descoberto, e depois de as haver, dentro com as próprias granadas e bombas do inimigo, e fora com a espada na mão, semearam a campanha de tantos corpos 
mortos, para cuja sepultura pedirem tréguas. Sementeira de que eles logo colheram o desengano, e nós pouco depois o fruto da vitória. ${ }^{61}$

Não, a vitória pertence a Deus, e ele a confere àqueles que são seus escolhidos e praticam a misericórdia, visto que "Deus é o Senhor dos exércitos, e que dá ou tira a vitória a quem é servido, por meio das armas, sim, mas sem a dependência delas." ${ }^{2}$

Porque o povo português é o povo escolhido para salvaguardar e dilatar a fé católica, por isso é merecedor da vitória:

"Salvou-se a Cidade de Salvador do perigo em que se viu tão apertada, mas não foi o numeroso de seus presídios, nem o valoroso de seus soldados o que a salvou. ${ }^{\text {,63 }}$

É interessante verificar em tal sermão a idéia velada de que, na guerra, os homens se nivelam e, mesmo para alguém como Vieira, versado na doutrina católica, na Neoescolástica, surpreendentemente, as diferenças entre eles se relativizam diante das circunstâncias e do momento, negros e índios são traduzidos como valorosos soldados empenhados em salvar a fé e a Bahia, ao lado dos portugueses.

Depois de tecer analogia da batalha na Bahia com diversas batalhas bíblicas e pagãs, Vieira revela que a vitória alcançada pala Bahia vem da Santa Casa de Misericórdia, onde são acolhidos os

\footnotetext{
${ }^{61}$ Sermão da visitação de Maria a Santa Isabel: pp. 219/220.

62 Idem: p. 220.

${ }^{63}$ Idem: p. 220.
} 
soldados feridos e onde o autor predica seu sermão. Com efeito, entende-se, no discurso de Vieira, que a guerra transforma os moradores da Bahia numa pequena amostra da Cristandade, envolvendo-os numa causa que, sendo material, tem motivação espiritual. Nesse momento, parece não haver mais a ideia do direito natural, segundo o qual

"Deus é o legislador supremo e afirma haver uma ordem jurídica natural criada por Ele, ordenando hierarquicamente os seres segundo sua perfeição e seus graus de poder, e determinando as obrigações de mando e obediência entre esses graus, em que o superior naturalmente comanda e subordina o inferior, o qual naturalmente Ihe deve obediência."

Isso porque todos são participantes da cidade de Deus e pelejam por ela contra um inimigo comum. E a misericórdia, sentimento imprescindível ao Cristianismo, surge mais uma vez como um grande toldo, sob o qual todos os cristãos se acolhem. Dessa maneira,

Os que militam debaixo da bandeira da Misericórdia, por diverso modo, ou são os Irmãos que exercitam as obras da mesma Misericórdia com os pobres e enfermos, ou são os mesmos pobres e enfermos, que eles sustentam,

\footnotetext{
${ }^{64} \mathrm{CHAUI}$, Marilena. Brasil: Mito fundador e sociedade autoritária, p. 64.
} 
remedeiam e curam: e posto que estes pareçam incapazes de pelejar, a uns e outros se deve igualmente a defensa da nossa Metrópole. ${ }^{65}$

Orientando-se pelo fato de que os sermões são representações de uma verdade transcendente, mas que precisam persuadir o público de tudo quanto dizem, Vieira busca, na sétima parte do Sermão da Visitação, referências e figuras nas mais diversas fontes. Além de se referir à Virgem, a respeito de sua intercessão junto a Deus pelo povo da Bahia, o autor remete à remota visão quinhentista de um índio que julgou ter visto à frente de um combate contra o gentio pagão, com a Virgem montada a cavalo, empunhando uma espada e um galho de palmeira.

Apesar de lembrar bem a figura de Diana, deusa da guerra na antiguidade pagã, Vieira acolhe essa imagem e acrescenta à figura uma coroa de galhos de oliveira, haja vista que simboliza a misericórdia para o Cristianismo ${ }^{66}$, já que do fruto da oliveira produzse o azeite, muito usado nos textos bíblicos para curar feridas físicas e espirituais.

Na oitava parte do Sermão, Vieira realiza um percurso pelos textos dos grandes Padres da Igreja e encontra uma interessante referência a dois corvos célebres das Escrituras: o corvo que atendeu a Noé, informando-Ihe sobre o fim do dilúvio e o corvo de

${ }^{65}$ Sermão da Visitação: pp. 225/ 226.

${ }^{66}$ Sermão da Visitação: p. 228: "Já veríeis a imagem da Virgem armada, e com a espada em uma mão, e a palma na outra; ou quero emendar esta imagem, porque mais parece gentílica que cristã. Aceito a palma em uma mão, e porque se não queixem os soldados, também a espada na outra: mas ainda lhe falta a esta pintura a principal insígnia da vitória. E qual é? A coroa". 
Elias, usado para alimentar o profeta quando fugia da perseguição de Acabe. Segundo o autor, esse corvo transforma-se em Irmão da Misericórdia, mostrando assim que Deus não escolhe o vetor do bem e todos, indiscriminadamente, podem-se tornar Irmãos da Misericórdia, por mais vil que seja sua natureza. Estaria o autor reportando-se aos nativos e africanos que lutaram pela defesa da cidade de Salvador? Pode ser, porém não se deve esquecer que aqueles que serviram como soldados, uma vez feridos, transformaram-se em pobres passivos, dignos de receberem a misericórdia dos ricos e fazê-los merecedores da eternidade com Deus.

Na nona parte é digna de análise a maneira como o jesuíta se refere ao pobre, deixando muito clara a sua utilidade na defesa da terra e da alma do cristão rico e piedoso, pois

"Também os pobres têm seus arraiais, e outro gênero de guerra, no qual pelejam por nós e nos defendem. Quem quiser ver esses arraiais, e a ordem, repartição e arquitetura militar deles, entre por essas enfermarias." (grifos nossos)

Considerando-se que, no Sermão das Obras de Misericórdia, Vieira eleva o pobre à condição do mais alto sacramento da Igreja, percebe-se a distância com que o autor refere-se ao pobre aqui. Vêse que, apesar de Cristo estar sob as espécies do pobre, este é o outro, situado lá embaixo, que o jesuíta contempla do alto de sua

${ }^{67}$ Sermão da Visitação: p. 231. (grifo nosso). 
celebridade. Isso nos faz retomar a imagem de São Martinho, citada na introdução desta tese. Com efeito, vamos encontrar Vieira a realizar esse movimento sempre que verbaliza acerca do pobre. $O$ pobre, na verdade, pode ser o índio, o negro, o mestiço, o branco desafortunado, mas não é o jesuíta, este que faz voto de pobreza.

$\mathrm{Na}$ décima parte do Sermão o autor deambula em companhia da Virgem pelas montanhas a fim de glorificar a Deus pelo grande privilégio. Assim, também a cidade de Salvador glorifica a Deus pela indescritível vitória contra os hereges. Porém, essa gratidão deve manifestar-se em ações e a principal delas, a mais esperada por Deus, é a demonstração da misericórdia para com os pobres, visto que

"Logo recolhidos os despojos, a parte também primeira deles dedicaram aos pobres, enfermos, órfãos, viúvas, e depois as primícias tão piamente empregadas; repartiam o demais entre si." ${ }^{\circ 68}$

Comparativamente à memorável luta de Judas Macabeu contra Nicanor em defesa da Terra Santa, os moradores da Bahia, que lutaram em defesa da fé católica contra os hereges, devem agir com a mesma misericórdia em relação aos despojos de guerra. Assim, ordena o autor que

"A primeira parte dos despojos da nossa vitória seja dos pobres enfermos e feridos deste hospital, e dos que a

\footnotetext{
${ }^{68}$ Sermão da Visitação: p. 237.
} 
mesma guerra, pela morte dos pais, ou maridos, fez órfãos e viúvas. "69

Tomando emprestada a autoridade dos Padres da Igreja, Vieira cita São Pedro Crisólogo para ratificar sua palavra, pois, segundo este, a paga dos pobres deve ser a primeira porque "os pobres nos livros ou nas matrículas de Deus são as primeiras planas" $^{\prime 70}$. E, como não podia deixar de ser, nota-se novamente o tom escatológico ao qual está vinculada a misericórdia, porque "pelos pobres se começa a paga geral do dia de juízo". ${ }^{71}$

Este Sermão remete-nos à segunda tentativa de invasão holandesa na Bahia. Dois anos após o fato, em carta escrita ao Geral da Companhia, Vieira relata que

"A oito de maio de 1624, apareceram de fora, na costa, sobre esta Bahia, 24 velas holandesas de alto bordo, com algumas lanchas de gávea."72

Nessa primeira investida,

Desarvoram e quebram as cruzes, profanam altares, vestiduras e vasos sagrados, usando dos cálices onde ontem se consagrou o sangue de Cristo, para em suas desconcertantes mesas servirem a Baco, e dos templos

\footnotetext{
${ }^{69}$ Idem: p. 237.

${ }_{71}^{70}$ Idem: p. 238.

${ }^{71}$ Idem: p. 238.

${ }^{72}$ Carta Ao Geral da Companhia de Jesus, setembro de 1626: p. 10.
} 
e mosteiros dedicados ao serviço e culto divino para suas abominações e heresias. ${ }^{73}$

Neste momento, é notório, no discurso de Vieira, um pavor muito grande de o Brasil ser tomado pela religião reformada. No decorrer de toda a carta citada, a preocupação territorial e a econômica ficam em segundo plano, embora a situação tenha deixado muitos portugueses, outrora bem estabelecidos, em extrema pobreza:

"Enquanto os holandeses se ocupavam nestes sacrilégios, cobriam os matos e praias os desterrados, que só dos portugueses seriam dez ou doze mil almas, servindo de casa a uns as árvores agrestes, e a outros o céu, sem mais algum abrigo da calma, chuvas e sereno da noite; todos a pé, muitos descalços e despidos, morrendo de fome e sede aqueles que, pouco havia, deixaram casas tão ricas $e$ abastadas de tudo, que mais pareciam servir ao regalo que à necessidade." ${ }^{\prime 7}$

Prevaleceram os batavos sobre os moradores da Bahia até 1625. Durante esse tempo, muitos moradores, por temor ou simpatia, renderam-se à amizade dos holandeses. ${ }^{75}$ Quando retomamos o Sermão da Visitação, observamos que o bom sucesso

\footnotetext{
${ }^{73}$ Idem: p. 15.

${ }^{74}$ Idem: pp.15/16.

${ }^{75}$ Idem: p. 30. "porque, sendo assim que muitos negros de Guiné, e ainda alguns brancos, se meteram com os holandeses, nenhum índio houve que travasse amizade com eles".
} 
descrito por Vieira foi fato de determinado momento e lugar, visto que, já estabelecidos em Pernambuco, os holandeses dominavam absolutos, disseminando sua religião, tocando seus engenhos e ali permanecendo até 1654. Relativamente a esse fato, Vieira escreve, em 1640, o magnífico Sermão pelo Bom Sucesso das Armas de Portugal contra as de Holanda. Num tom absolutamente épico, o jesuíta esbraveja e dirige-se não ao povo, mas a Deus, a fim de questionar o porquê do domínio batavo. Diferentemente do sermão aqui analisado, o de 1640 não evoca a caridade, mas urge a destruição total do inimigo e do traidor. 


\section{CAPÍTULO IV}

\section{SERMÃO XIV DO ROSÁRIO: A POBREZA DO CATIVEIRO É A SENDA DA SALVAÇÃO}

Apesar de ser mais uma representação a partir da realidade presenciada pelo autor, o Sermão XIV do Rosário, como todos os sermões de Vieira, segue as convenções estilísticas próprias da época: comporta verdades ocultas, traços da realidade histórica, econômica e social vivida pelo autor e tenta persuadir o público por meio de descrições surpreendentes. Esse Sermão faz parte de uma série de sermões escritos em louvor aos mistérios do rosário de Nossa Senhora. Particularmente neste, em estudo, Vieira analisa, pela perspectiva unicamente teológica, a condição dos escravos africanos.

Escrito em 1633, o Sermão XIV traduz a ideia central de toda a série, que é homenagear a Virgem do Rosário. A questão da escravidão africana apresenta-se aqui porque as Irmandades de Nossa Senhora do Rosário eram as únicas, naquela época, que aceitavam integrantes negros, diferentemente das Irmandades do Santíssimo Sacramento, que só aceitavam brancos, e das de Nossa Senhora das Mercês, que acolhiam os mulatos ${ }^{76}$. Observam-se, assim, as organizações religiosas que colaboraram efetivamente para o estabelecimento das dinâmicas sociais bem próprias da

\footnotetext{
${ }^{76}$ BOSI, Alfredo. Vieira ou a cruz da desigualdade. In Dialética da Colonização: p. 143.
} 
colonização, um verdadeiro dégradé no reduto da Cristandade. Era o Novo Mundo organizado por cor e por condição.

A propósito, a confraria de Nossa Senhora do Rosário chegou ao Brasil ainda no século XVI, trazida pelos padres dominicanos. Isso se justificava pelo fato de São Domingos ter sido seu fundador ainda no século XIII. Foi muito bem aceita na Colônia pelos jesuítas porque, como todas as ordens católicas, apresentava forte tradição mariana.

No Sermão XIV do Rosário, Vieira justifica a situação dos escravos em conformidade com o pensamento vigente: apesar de 0 direito natural, invocado no Concílio de Trento, no século XVI, prever que a liberdade é inerente a todos os homens, reescrita por outras letras, que atendiam às necessidades de conquista e domínio, a escravidão no Brasil e demais domínios portugueses transformou-se na mais pura expressão da misericórdia. Guiado constantemente pela diretriz da providência, o jesuíta relaciona a escravidão ao plano divino para a salvação do gentio africano. Assim, a pena e as dores do trabalho forçado comportam a recompensa da salvação por meio do conhecimento do Cristianismo, porquanto o contato com os portugueses possibilitou a redenção dos africanos, outrora perdidos em seus ritos pagãos.

Todavia, antes da análise propriamente dita do Sermão, é interessante observar a sua organização estrutural. Vale observar que ele é composto de nove partes, e no decorrer do texto o autor trabalha, propositadamente, fazendo referência ao número três: na parte II temos três dias em um dia; três festas em uma festa, "festa 
de São João, festa da Senhora do Rosário e festa dos Pretos devotos $^{\text {"77 }}$; três nascimentos, três filhos, assim descritos:

"Multiplicando este nascimento em três nascimentos, este nascido em três nascidos, e este Filho em três filhos, todos três nascidos de Maria Santíssima; esta mesma será a matéria do Sermão, dividido também em três partes. Na primeira veremos com o novo nascimento nascido de Maria a Jesus; na segunda com outro novo nascimento nascido de Maria a São João; e na terceira, também com novo nascimento, nascidos de Maria aos Pretos seus devotos. ${ }^{178}$

Ainda há o terceiro nascimento de Cristo para Maria, o início do ministério de Cristo aos trinta e três anos, os três mistérios do Rosário - gozosos, dolorosos e gloriosos, os três madeiros da cruz dos escravos, três salmos de Davi que contam a trajetória de Cristo: oito, oitenta e oitenta e três; três orações de Cristo na cruz. Ora, não é novidade que, dentro do Cristianismo, o número três sustenta os temas mais importantes. A começar pela Trindade - Pai, Filho e Espírito Santo - que é o símbolo mais importante, pois traduz toda a tentativa de se cultivar uma fé monoteísta. Trinta e três era a idade de Cristo quando começou seu ministério, três eram os discípulos no barco em meio à tempestade - Pedro, Tiago e João; três eram as Maria ao pé da cruz. Enfim, como não é esse o nosso propósito em

\footnotetext{
${ }_{77}$ Sermão XIV do Rosário: p. 636.

${ }^{78}$ Idem: p. 636/637.
} 
relação ao Sermão em estudo, tomamos as referências acima apenas como observações.

Voltando à análise do Sermão XIV, é nítida a necessidade de se estabelecer o contexto temporal e ideológico no qual Vieira estava inserido, visto que a veemência de seu discurso e suas afirmações violentam o raciocínio de qualquer leitor desavisado. A priori sabemos que os escravos africanos, bem como os indígenas, não estavam inseridos em nenhuma categoria social do mundo luso seiscentista. Portanto, eles não eram os pobres. Sendo assim, não obstante a exposição sucinta dos sofrimentos dos negros no engenho, não há qualquer sombra de demonstração de misericórdia no sentido de suprir suas necessidades materiais. $E$ se isso ocorresse traria em si um sentimento muito distante da piedade cristã, como sugere Antonil em seu livro Cultura e Opulência do Brasil, para quem a misericórdia tem por finalidade suscitar obediência e estimular multiplicação do corpo servil ${ }^{79}$.

A complexidade na qual mergulharam as sociedades europeias, no limiar da Idade Moderna, prevaleceu até o século XVII, e para Portugal, particularmente, isso se intensificou em virtude de suas características de nação extremamente religiosa. Não há como negar que a rigidez das doutrinas contrarreformistas fez da cultura ibérica uma das mais avessas a mudanças. Por isso, não é fácil compreender a dinâmica da misericórdia no contexto dos engenhos

\footnotetext{
${ }^{79}$ Apud BOSI, Alfredo. Dialética da Colonização.Ver que os senhores têm cuidado de dar alguma coisa dos sobejos da mesa aos seus filhos pequenos é causa de que os escravos se sirvam de boa vontade e que se alegrem de lhes multiplicar servos e servas. Pelo contrário, algumas escravas procuram de propósito o aborto, só para que não cheguem aos filhos de suas entranhas o que elas padecem: p. 164.
} 
movidos por braços escravos. Malgrado a, bula papal Sublimis Deus de 1537 declarar que os índios e demais povos que porventura venham ao conhecimento do Cristianismo são dotados de livrearbítrio, e consequentemente dignos de plena liberdade, como já dito acima, o projeto colonial traçado para os domínios portugueses revelava outra situação: em face da demanda comercial, os europeus, mormente os portugueses e os espanhóis, não podiam prescindir da mão-de-obra indígena nem africana. Estamos aqui, então, diante da letra que registra um pensamento e da realidade que configura ação bem distinta. Nesse contexto, Vieira descreve o cativeiro africano no Brasil, tendo consciência clara da precariedade em que viviam os escravos e de como eram explorados até a última gota de seu sangue e, assim, comparando aquele à própria crucificação de Cristo:

"Em um engenho sois imitadores de Cristo crucificado, porque padeceis em um modo muito semelhante o que o mesmo Senhor padeceu na sua cruz, e em toda a sua paixão. A cruz foi composta de dois madeiros, e a vossa em um engenho é de três. Também ali não faltaram as canas, porque duas vezes entraram na paixão: uma vez servindo para o cetro do escárnio, e outra vez para a esponja com que Ihe deram fel."ק0

Ao retornarmos ao Sermão das Obras de Misericórdia, observamos que, nele, o pobre descrito pelo orador é o próprio

\footnotetext{
${ }^{80}$ Sermão XIV do Rosário: p. 651.
} 
Cristo. Entretanto, neste, o desafortunado é apenas comparado a Cristo em sua hora de maior agonia. O pobre do outro sermão comportava Cristo sob suas espécies, enquanto o escravo é somente imitador de Cristo em seu momento mais vulnerável. Como mártires, os africanos pagam as suas penas num engenho de açúcar, expiam neles a culpa dos colonizadores.

Nota-se, aqui, que a cana se tornou um elemento amaldiçoado pelo autor, pois aparece duas vezes no episódio da crucificação de maneira bastante negativa: na primeira vez, tornou-se cetro de escárnio; na segunda, apoiou a esponja com a qual fizeram Cristo tomar vinagre.

É o contínuo extermínio de forças e de vida que ocorreu na paixão de Cristo: "a paixão de Cristo parte foi de noite sem dormir, parte foi de dia sem descansar, e tais são as vossas noites e os vossos dias" ${ }^{\prime \prime}$.

Nessa fadiga contínua e desumana gastavam-se suas vidas diante das fornalhas e das infindáveis lavouras de corte. "Moinhos de gastar gente" ${ }^{82}$, foi isso que se tornou a colonização do Brasil.

A descrição da violência e do vilipêndio suportados pelos escravos leva-nos a pensar se realmente Vieira concordava com tal situação. Considerando-se sua vivência na Europa, em países totalmente inseridos na Modernidade, ser-Ihe-ia difícil não ser contaminado por ideias diferentes daquelas veiculadas pela

\footnotetext{
${ }^{81}$ Sermão XIV do Rosário: p. 651.

82 RIBEIRO, Darcy. "A empresa escravista, fundada na apropriação de seres humanos através da violência mais crua e da coerção permanente, exercida através dos castigos mais atrozes, atua como uma mó desumanizadora e desculturadora de eficácia incomparável". in O Povo Brasileiro - A formação e o sentido do Brasil: p. 118.
} 
Contrarreforma. Contudo não se deve esquecer de que estamos diante de um sermão que, embora estabeleça uma fronteira muito tênue com a realidade, não é a descrição da mesma. Assim prossegue:

"Cristo despido e vós despidos: Cristo sem comer e vós famintos: Cristo em tudo maltratado e vós maltratados em tudo. Os ferros, as prisões, os nomes afrontosos, de tudo isso se compõe a vossa imitação, que se for acompanhada de paciência, também terá merecimento de martírio."ק3

O Sermão XIV foi escrito em 1633 em homenagem à Irmandade de Nossa Senhora do Rosário dos Homens Pretos de um engenho na Bahia. Após descrever os três nascimentos realizados pela Virgem, ele afirma, na parte $V$ do sermão, que os negros fazem parte do terceiro nascimento, pois é pela piedade e intervenção de Nossa Senhora que eles foram aceitos no seio do Cristianismo. São frutos do terceiro nascimento porque vieram à luz do Evangelho pelo sofrimento da crucificação. Assim, é conveniente comparar o engenho à cruz de Cristo. Todavia, qual é a origem desses pretos, delineados tão distintamente naquele sermão de Vieira? "O povo dos etíopes", responde o autor:

"De maneira que vós os Pretos, que tão humilde figura fazeis no mundo, e na estimação dos homens; por vosso próprio nome, e por vossa própria nação, estais escritos e

\footnotetext{
${ }^{83}$ Sermão XIV do Rosário: p. 651
} 
matriculados nos livros de Deus, e nas Sagradas Escrituras: e não com menos título, nem com menos foro, que de filhos da Mãe do mesmo Deus." 84

Não obstante a representação da misericórdia e o tom de aceitação dos negros como irmãos, integrantes da Cidade de Deus, unidos por uma esfera transcendente, todavia, separados no plano imanente, o abismo se aprofunda quando Vieira deixa-se trair pelo próprio discurso ao situar os homens pretos num patamar questionável em relação aos outros homens, momento em que cita a questão da humilde figura na estimação dos homens. Percebe-se que, apesar de todas as suas letras e conhecimento universal, o jesuíta não é capaz de se desvencilhar do pensamento que o formou que, além de ser absolutamente religioso, era próprio de sua época.

Por isso, quando toma para si a autoridade dos doutores da Igreja, reafirma sua tradição ao repetir as palavras de São Tomás, arcebispo de Valença, segundo o qual os Etíopes e os Pretos são colocados em último lugar na descrição do Salmo III, porque este é o lugar que Ihes conferem os homens. Entretanto, apesar de situação tão desconfortável,

"Saibam, pois os Pretos, e não duvidem que a mesma Mãe de Deus é Mãe sua: Sciant ergo ipsam matrem: e saibam que com ser uma Senhora tão soberana, e Mãe tão

${ }^{84}$ Idem: p. 642. 
amorosa, que assim pequenos, como são, os ama, e tem por filhos.

Como filhos por adoção, os negros finalmente chegam ao conhecimento da "verdade" e têm legitimada sua devoção quando ingressam na Irmandade. Pela devoção ao Rosário da Virgem, os escravos vislumbram a luz da salvação e recebem o passaporte para o Céu, posto que sutil, dentro de uma sociedade que não pode prescindir deles. Não se engane o leitor: esse ingresso é apenas espiritual, e esses escravos só são dignos de tal distinção, percebida no discurso de Vieira, porque são participantes da devoção ao Rosário de Maria.

O traslado dos africanos para terras americanas, historicamente conhecido como tráfico negreiro, é tomado como justificativa para um novo nascimento. Conquistado por meio da dor do cativeiro, é ratificado pelo discurso do maior letrado da língua portuguesa, no século XVII. A analogia entre o cativeiro negro e a crucificação de Cristo surge como uma diretriz para incentivar e acrescentar a devoção ao Rosário da Virgem. Contudo, em face do labor continuo,

"Quando não possais rezar todo o Rosário da Senhora, ao menos com partes das três partes em que ele se divide, haveis de aliviar e santificar o peso do vosso trabalho na memória e louvores dos seus mistérios. "86

\footnotetext{
${ }^{85}$ Sermão XIV do Rosário: p. 643.

${ }^{86}$ Sermão XIV do Rosário: p. 653.
} 
De fato, não havia tempo para reflexão dentro de um engenho de açúcar, onde a prioridade era o lucro e o escravo tinha seu lugar definido: o trabalho até a exaustão. Talvez, por esse motivo, pode-se deparar com a descrição de uma celebração ao Rosário da Virgem, em carta escrita em 1653, ao provincial do Brasil, no Maranhão, onde não há qualquer referência à presença de escravos africanos, muito menos organizados, em confrarias. ${ }^{87}$ Há simplesmente uma referência sutil à participação de gente de todos os estados. Todavia, sabe-se que os escravos negros não estavam inseridos em nenhum dos três estados citados por Vieira. Logo, mesmo sabendo que naquela região já existiam engenhos de açúcar movidos pela força dos escravos importados, não se registra a participação dos mesmos naquela cerimônia religiosa. É interessante registrar a grande importância que essa festa mariana representava para os portugueses, tanto que, em domínios holandeses, tornava-se estopim para violentas brigas religiosas, desiludindo aqueles que pensam o Brasil holandês como território "democrático" e livre para qualquer credo. Com efeito, registra esta Ata do Sínodo e Classes do Brasil Holandês:

"D. Velthusen communica que sobreviveu em Serinhaem certa difficuldade por causa da procissão do ídolo do Rosário, onde bons Christãos, que se achavam na rua,

\footnotetext{
${ }^{87}$ Seguindo o fervor da gente, e desejando que todos fizessem algum serviço geral e público à Virgem Senhora Nossa, cuja invocação é a dessa Igreja, preguei em dia da Anunciação, e publiquei para que daquela tarde em diante se rezasse o Terço do Rosário a coros, como se usa em São Domingos de Lisboa e em outras muitas igrejas da mesma cidade. Vêm por obrigação todos os estudantes e meninos da nossa escola; seguem a estes muitos soldados e gente de todos os estados: p. 114.
} 
vendo aquillo e recusando-se a fazer reverências, não somente foram maltratados, mas também levaram pancadas. Ficou resolvido representar sobre essa e outras que taes porcarias dos Papistas a S. Ex. e ao Supremo Conselho." ${ }^{\text {.88 (grifos nossos) }}$

Considerando-se que a festa do Rosário e a devoção a Nossa Senhora era uma das raríssimas ocasiões em que os negros, ainda que timidamente, se visibilizavam, à margem da organização social vigente, observa-se que, mesmo sendo aquela uma atividade religiosa, era bastante restrita no tocante à população escrava e se, por algum motivo, fortaleceu-se na Bahia, tornando-se um grêmio representativo de reação, o mesmo não ocorreu no Maranhão e não conferiu aos negros africanos qualquer privilégio diante de seus senhores em nenhuma parte do Brasil.

Para o negro, o cativeiro tornou-se um lugar eterno, tanto físico quanto psicológico. Da mesma forma, ao voltarmos os olhos para a região da Capitania de Pernambuco, dominada pelos holandeses, encontramos proposta semelhante, mas que também favorecia a devoção dos escravos, oferecendo-lhes os domingos livres para assistirem aos cultos. Vê-se, assim, "acerca da falta de religião dos negros - que se deve determinar que assistam a prédica aos domingos e que não profanem o dia do Senhor com trabalhos e

\footnotetext{
${ }^{88}$ Sessão Sétima das Actas da Classe do Brasil, reunida no Recife, em 17 de outubro de 1641. Apêndice de Tragédia na Guanabara, de Jean Crespin: pp. 144/145.
} 
dansas". ${ }^{89}$ Contudo, isso não significa que os holandeses pensavam diferentemente em relação à fortuna dos africanos, principalmente quando se questiona se

\begin{abstract}
"É licito a um Christão comprar e vender Negros para escravizal-os; Remedium. Visto que os doutores christãos opinam que o principal fim da acquisição dos Negros é de trazel-os á egreja e instruil-os na religião christã, quando as circunstâncias o permitiram, não importando de que religião sejam os donos; essa condição deve ser imposta na venda dos Negros.
\end{abstract}

De volta ao Sermão XIV, vemos que Vieira, visando a defender uma situação estabelecida, insiste na ideia de que os negros foram realmente predestinados ao cativeiro e à servidão. Ao apresentar os três mistérios do Rosário da Virgem, afirma que os mais propícios para os escravos são os dolorosos. Para isso, reporta-se ao episódio da conversão do etíope, conduzida por São Felipe. Conforme o texto bíblico registrado em Atos dos Apóstolos, o etíope lia o livro do profeta Isaías justamente nos passos da crucificação e morte de Cristo. Vieira admite o fato como feliz coincidência para a realização da correspondência entre a fortuna daquele negro recém-convertido e a sina dos escravos africanos trazidos para o Brasil. Segundo o

\footnotetext{
${ }^{89}$ Sessão Primeira das Actas da Classe realizada no Recife de Pernambuco, Brasil em 20 de abril do anno de 1640 de Nosso Senhor. in Tragédia na Guanabara: pp.117/118.

${ }^{90}$ Sessão quarta das Actas da Assemblea Classical do Brasil, de 5 de janeiro de 1638, Pernambuco: p. 92.
} 
autor, aquele encontro foi um admirável mistério, e explica com particular satisfação:

"Que o lugar fosse da Paixão e paciência de Cristo; porque para dar ocasião ao Diácono de pregar a Fé a um gentio, bastava que fosse qualquer outro. Pois por que ordenou Deus que fosse sinaladamente aquele lugar, em que se descrevia a sua Paixão, e os tormentos com que havia de ser maltratado, e a paciência, sujeição e silêncio com que os havia de suportar?" 91

Apesar das figuras e das analogias bem dispostas no Sermão, não se percebe qualquer sombra de revolta ou iniciativa de reação contrária àquele estado de coisas. O que se revela com muita nitidez é a crença na predestinação e providência divinas, pois

"Quis Deus que nascessem à Fé debaixo do signo de sua Paixão, e que ela, assim como Ihe havia de ser o exemplo para a paciência, Ihe fosse também o alívio para o trabalho. Enfim, que de todos os mistérios da Vida, Morte e Ressurreição de Cristo, os que pertencem por condição aos Pretos, e como por herança, são os dolorosos."92

Aliás, a supervalorização do sofrimento a que se submete o ser humano a fim de cultivar a esperança numa felicidade no porvir é

91 Sermão XIV do Rosário: p. 655.

92 Idem: p. 655. 
bem típica do código doutrinário da Contrarreforma. Pela tentativa de reavivar os índices medievais como legítimos pilares da fé católica, o sofrimento pessoal ocupa lugar privilegiado. Assim, percebe-se o elogio à dor, tecido eloquentemente no Sermão, como clara intencionalidade de redefini-lo como algo bom. Portanto, algo que deve ser aceito e suportado com paciência. Para os negros, o sofrimento é o legado de seu antepassado etíope que conheceu Cristo já pendurado na cruz, moído, vituperado e flagelado.

Talvez não aceitassem os escravos tal situação se tivessem acesso a outros trechos da Escritura, principalmente àqueles dos Evangelhos que dizem

Verdadeiramente, ele tomou sobre si as nossas enfermidades e as nossas dores ele levou sobre si; e nós o reputamos por aflito, ferido de Deus e oprimido (...). O castigo que nos traz a paz estava sobre ele e pelas suas pisaduras fomos sarados.

Lamentavelmente, o reino do Messias que se pregava, naquela época, para os fracos, era de sofrimento e dor, enquanto a parte da abundância e da liberdade ficava reservada aos privilegiados. Mesmo diante da consciência de que o sermão não traduz "verdade real", mas a representação dessa verdade, Vieira registrou com letras bem nítidas a maneira como se configurava a escravidão africana do Brasil e o tratamento dispensado aos negros dentro dos engenhos.

\footnotetext{
${ }^{93}$ Isaias, capítulo 53, versículos 5 e 6 . Ao discorrer sobre o Reino do Messias, o profeta traça um panorama de como ele será, descrevendo a paz, a prosperidade e a liberdade que serão inerentes a esse Reino.
} 
A descrição detalhada do trabalho exaustivo diante das labaredas das fornalhas onde se purificava o açúcar fornece a ideia de um desintegrador de gente. Para os africanos não havia alternativa. Segundo Ribeiro,

"Se fugia e era apanhado, podia ser marcado com ferro em brasa, tendo um tendão cortado, viver peado com uma bola de ferro, ser queimado vivo, em dias de agonia, na boca da fornalha ou, de uma vez só, ser jogado nela para arder como um graveto oleoso."94

Muito diminuta é a pobreza descrita no Sermão das Obras de Misericórdia diante das cores fortes e dos traços bem marcados do discurso de Vieira quando pincela no painel da História a rotina nas fornalhas nesse Sermão XIV do Rosário. Não é a simples pobreza, a falta de bens materiais, mas é a desumanização forjada por terceiros e declarada além do tempo e do espaço:

"O ruído das rodas, das cadeias, da gente toda da cor da mesma noite, trabalhando vivamente, e gemendo tudo ao mesmo tempo, sem momento de tréguas, nem de descanso: quem vir enfim toda a máquina e aparato confuso e estrondoso daquela Babilônia não poderá

\footnotetext{
${ }^{94}$ RIBEIRO, Darcy. "Moinhos de gastar gente". in O povo Brasileiro - a formação e o sentido do Brasil: p. 120.
} 
duvidar, ainda que tenha visto Etnas e Vesúvios, que é a semelhança de Inferno."

O forte teor da descrição não apresenta qualquer sugestão de misericórdia ou de sentimento pungente e solidário. O certo é que o escravo é o outro, analisado à distância, o do outro lado do rio. Apesar de a pobreza material despertar a caridade e os sentimentos mais nobres do Cristianismo, capazes de transformar em realidade a concepção de um grande laço que une todos os homens e os leva a doar, porquanto o outro é seu irmão, ocorreu com os africanos o inenarrável despojamento de sua humanidade, sem que ninguém manifestasse por eles qualquer sombra de compaixão. E foi esse estigma que atravessou as gerações e rompeu os séculos, fazendo diferente a pobreza do negro da pobreza do branco. Prossegue 0 autor:

"Mas, se entre todo esse ruído, as vozes que se ouvirem forem as do Rosário, orando e meditando os mistérios dolorosos, todo esse inferno se converterá em Paraíso; o ruído em harmonia celestial; e os homens, posto que pretos, em Anjos."

Continuam as analogias. Se, por meio da devoção do Rosário, o Inferno converte-se em Paraíso, da mesma maneira esses homens que mais parecem corvos, pela sua negritude, podem tornar-se

\footnotetext{
${ }^{95}$ Sermão XIV do Rosário: pp. 655/656.

${ }^{96}$ Sermão XIV do Rosário: p. 656.
} 
pombas. Não pelo fato de terem asas e usufruírem de plena liberdade, mas pelo fato de a pomba não cantar, visto que os cativos não cantam, só gemem. E hão de gemer, orar e meditar nos mistérios dolorosos de Cristo, contidos no Rosário da Virgem, pois só assim

"O ferro se Ihe converte em prata, o cobre em ouro, a prisão em liberdade, o trabalho em descanso, o inferno em paraíso, e os mesmos homens, posto que pretos, em Anjos."97

$\mathrm{Na}$ tentativa de persuadir seus interlocutores - ele predica diretamente aos escravos - Vieira apela para a distinção de suas orações ao Rosário, convidando-os a fazer coro com os anjos. Com efeito, "sem suas vozes, o Rosário que se entoa no Céu não seria perfeito".

Finalmente, ratifica-se a dicotomia entre vós (escravos) e eles (senhores), e o que resta desta "organização social" e ideológica é o grande abismo cavado de maneira espetacular pelo próprio orador:

"Os dolorosos (ouçam-me agora todos), os dolorosos são os que vos pertencem a vós, como os gozosos aos que, devendo-vos tratar como irmãos, se chamam vossos senhores. Eles mandam, e vós servis; eles dormem e vós velais; eles descansam, e vós trabalhais; eles gozam o fruto

\footnotetext{
${ }^{97}$ Idem: p. 657.
} 
dos vossos trabalhos, e o que vós colheis deles é um trabalho sobre outro. Não há trabalhos mais doces que os das vossas oficinas; mas toda essa doçura para quem é? Sois como as abelhas, de quem disse o poeta: Sic vos non vobis mellificatis apes. O mesmo passa em vossas colméias. As abelhas fabricam o mel, sim; mas não para si. $E$ posto que os que logram é com tão diferente fortuna da vossa; se vós, porém vos souberdes aproveitar dela, e conformá-la com o exemplo e Paciência de Cristo, eu vos prometo primeiramente que esses mesmos trabalhos vos sejam muito doces como foram ao mesmo Senhor. "98

Não existe resgate de tão decadente fortuna, mas a configuração e o fortalecimento da fenda. E essa disparidade só pode ser resolvida por meio da espiritualização. Nesse momento, é bastante pertinente o mandamento da paciência em imitação à paciência de Cristo. Mormente porque

\begin{abstract}
"Assim como Deus vos fez herdeiros de suas penas, assim o sereis também de suas glórias: com condição, porém, que não só padeçais o que padeceis, senão que padeçais com o mesmo Senhor, que isso quer dizer Compatimur. Não basta só padecer com Cristo, como S. João."99
\end{abstract}

\footnotetext{
${ }^{98}$ Sermão XIV do Rosário: p. 657.

99 Sermão XIV do Rosário: p. 658.
} 
Assim, tudo se resume numa equação: negro / escravo = mistérios dolorosos, branco $/$ senhor = mistérios gozosos. Todas as coisas e seres devem permanecer no seu lugar determinado por Deus e confirmado pelos homens. $O$ cativeiro dos negros capturados na África e trazidos para o Brasil deu-se conforme as circunstâncias de ascendência e decadência dos engenhos, mas seus descendentes não ficaram imunes da condição de seus pais. A escravidão transformou-se em pobreza crônica, anunciada e velada para que permanecesse intacta no transcorrer dos séculos. 


\title{
CAPÍTULO V
}

\section{SERMÕES DA EPIFANIA E DO ESPÍRITO SANTO- A POBREZA NO ÍNDIO}

\begin{abstract}
Apesar de a cristianização trajar sempre o hábito da misericórdia, seu real objetivo no Novo Mundo era o de domínio. $\mathrm{Na}$ iconografia colonial um bom indicativo disso é uma ilustração encontrada no Arquivo Ultramarino de Portugal (figura V, abaixo), onde vemos um índio submisso render-se aos pés do jesuíta, enquanto o outro é segurado por aquele, pelo ombro, para não se levantar.
\end{abstract}

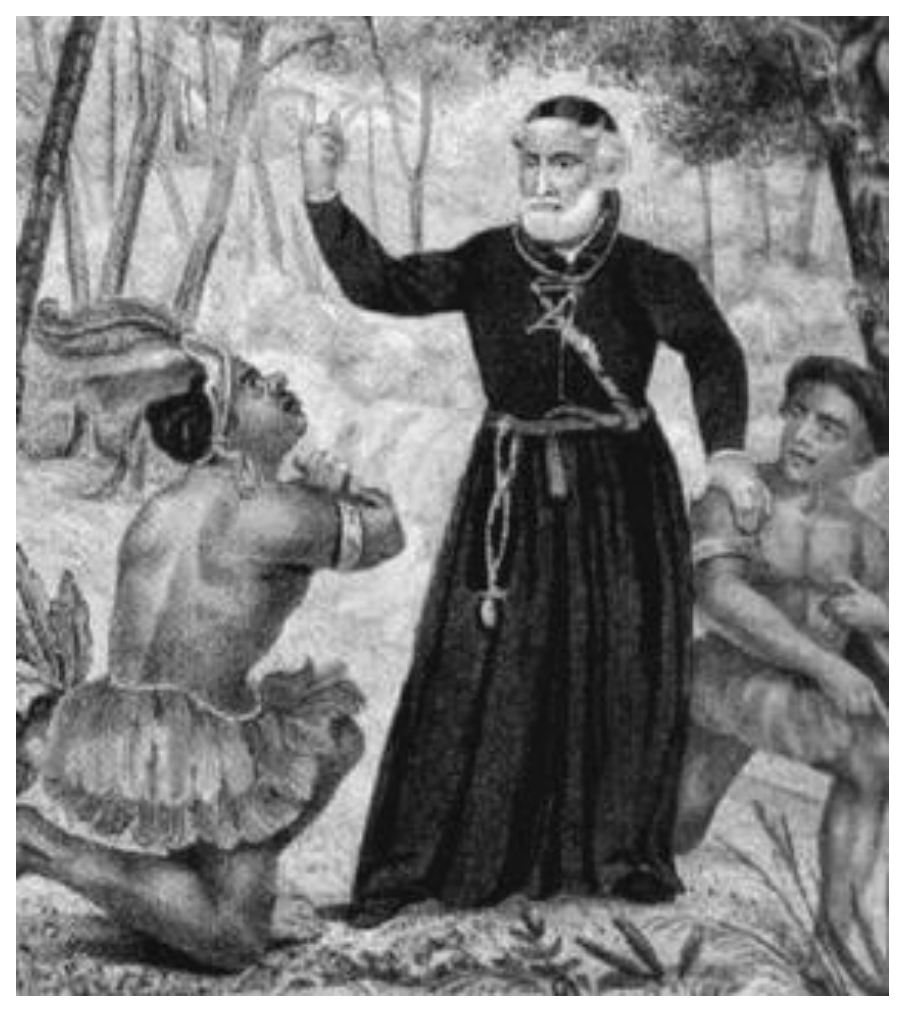

Figura V - Vieira e os Índios 
Como qualquer obra literária produzida sob os índices da Contrarreforma, os sermões vieirenses não podem ser analisados sem se considerar que são fortes representações da verdade, de uma verdade absoluta que o orador procura redesenhar por meio de figuras e analogias a fim de adequá-la ao intelecto do público. Assim, é muito comum e até possível encontrar metáforas e figuras dos sermões em suas cartas. Como documentos de transposição - e não representação - da realidade, o epistolário de Vieira segue também o estilo preconizado pela lógica aristotélica ao se referir ao índio, argumentando de maneira lógico-teológica a questão da razão. Segundo Hansen (2008), seu método de argumentação é lógicoretórico e funde metafísica, dialética, retórica e semântica. ${ }^{100}$ Por isso, dentro da esfera transcendente na qual Vieira localiza seu discurso, as fronteiras com a realidade são muito tênues e quase imperceptíveis.

Seguindo os conceitos de escrita, rigidamente em conformidade com a doutrina neoescolástica, Vieira traça uma interessante imagem do nativo brasileiro, num pensamento que funde missão como privilégio do povo português e obrigação do Rei e a concepção da lei natural segundo a interpretação tridentina. Se no Sermão da Epifania a grande dificuldade das missões está centrada na disputa com os colonos, no do Espírito Santo todo problema está nas diversidades linguísticas. Todavia, nos dois

\footnotetext{
${ }^{100}$ HANSEN, J.A., Sistemas doutrinários da representação nas obras de Antônio Vieira. in Vieira, Vida e Palavra: p.158
} 
sermões, há supervalorização do trabalho jesuítico junto aos nativos, principalmente porque

"Nestas terras é ainda necessário muito mais amor de Deus, que em nenhuma outra. E por quê? Por dois princípios: o primeiro, pela qualidade das gentes; o segundo pela dificuldade das línguas."

Não há dúvida de que a qualidade das gentes representava o maior impasse para a dilatação do Evangelho. $E$ o que impressionava os missionários não era a dureza dos corações dos brasis, mas sim a sua incurável inconstância. Segundo Vieira, mesmo depois de São Tomé ter estado nesta terra e ter pregado o Evangelho, a mensagem do cristianismo aqui não se radicou porque "há-se de estar sempre ensinando o que já está aprendido, e há-se de estar sempre plantando o que já está nascido, sob pena de perder o trabalho e mais o fruto". ${ }^{101}$ Diferentemente dos povos da Índia e do Japão, as nações do Brasil tudo aceitam de imediato, bem como tudo negam e esquecem prontamente. Muito diferentes dos Magos do Oriente, que foram guiados pela estrela ao encontro de Cristo recém-nascido, as estrelas do século XVII, os jesuítas, não guiam pagãos sábios e cheios de ciência, mas guiam e "acomodamse à gente mais sem entendimento e sem discurso de quantas criou

\footnotetext{
${ }^{101}$ Sermão do Espírito Santo: p. 424.
} 
ou abortou a natureza, e a homens de quem se duvidou se eram homens". ${ }^{102}$ (grifo nosso)

A constante depreciação da figura do nativo brasileiro é a tópica dos dois sermões, realizando, assim, um parâmetro de julgamento que prevalece em todos os escritos coloniais. Jamais o leitor irá encontrar a consideração do índio, nos escritos de língua portuguesa, como um ser humano completo e digno. Pouco se cogitou de que a terra do Brasil pertencesse ao nativo. Aqui era a terra prometida e os pagãos deviam ser convertidos ou desarraigados. A terra como dom de Deus ao cristianíssimo povo português devia ser limpa e "reflorestada" com a verdade e a luz do Evangelho. O Brasil era lugar de trevas espessas que devia ser iluminado pela ação dos missionários. Assim, justifica-se a analogia feita por Vieira entre a estrela que guiou os magos e os jesuítas que tentavam guiar os pagãos brasis. Apesar de tais considerações, em certos momentos percebe-se um lapso de consciência que o aproxima dos humanistas do século XVI. Numa carta ao Rei Dom Afonso VI, lamenta o autor que

\begin{abstract}
"As injustiças e tiranias, que se têm executado nos naturais destas terras excedem e muito às que se fizeram na África. Em espaço de quarenta anos se mataram e se destruíram por esta costa e sertões mais de dois milhões de índios, e mais de quinhentas povoações como grandes cidades."103
\end{abstract}

\footnotetext{
102 Sermão da Epifania: p. 610.

${ }^{103}$ Carta ao Rei D. Afonso VI, 20 de abril de 1657: p. 196.
} 
O reconhecimento dos males causados pela colonização chega ao extremo quando Vieira se inclui como agente da destruição das nações indígenas. Observa-se que, nesse processo, o autor também alude às missões realizadas pelos jesuítas:

"E nós não só consentimos que percam a sua Pátria aqueles Gentios, mas somos os que à força de persuasões e promessas (que se Ihes não guardam) os arrancamos de suas terras, trazendo as Povoações inteiras a viver e a morrer junto das nossas. Cristo não consentiu que os Magos perdessem a soberania, porque Reis vieram e Reis retornaram: e nós não só consentimos que aqueles Gentios percam a soberania natural com que nasceram e vivem isentos de toda sujeição; mas somos os que sujeitando-os ao jugo espiritual da Igreja, os obrigamos também, ao temporal da Coroa, fazendo-os jurar vassalagem."104

Está claro, no discurso de Vieira, o conflito que vivia e a distância entre o que pensava e o que fazia. A despeito do projeto colonial com o qual contribuía, descendo índios de suas terras e cristianizando-os, a despeito de reduzi-los nos aldeamentos, fragmentando sua cultura e tornando-os arremedos de brancos, Vieira possuía total consciência daquilo que realizava e os males a que submetia as nações indígenas. Quem sabe, nos escritos do jesuíta esta seja a página mais contundente e mais sofrida para ele,

\footnotetext{
${ }^{104}$ Sermão da Epifania: p 620.
} 
porém a que mais o qualifica e o torna singular. Revela-se aqui um sentimento de humanidade que transcende as fronteiras da religião e do poder do Rei. O autor sabe que aniquila o nativo quando o obriga ao Cristianismo e à obediência. Todavia, ele não pode conter o fluxo da História. O nativo precisa ser inserido no projeto colonial, mesmo que esse projeto o lance na pobreza eterna.

Esse povo boçal e sem razão, residente nessa terra imersa em trevas, é lançado automaticamente numa situação de constante miséria no âmbito do projeto colonial. Negavam-se-lhe alma, decisão, civilidade, inteligência e espiritualidade. Vieira também revela a sua pobreza de bens materiais e encara o nativo como um ser vulnerável e em constante dependência dos missionários. É outra face de pobreza, descrita tão primorosamente por Vieira no Sermão da Epifania:

"A Estrela dos magos fez a sua missão entre púrpuras e brocados, entre pérolas e diamantes, entre âmbares e calambucos; enfim, entre os tesouros e delícias do Oriente: as nossas Estrelas fazem as suas missões entre as pobrezas e os desamparos, entre os ascos e as misérias da gente mais inculta, da gente mais pobre, da gente mais vil, da gente menos gente de quantos nasceram no mundo."105 (grifos nossos)

\footnotetext{
${ }^{105}$ Sermão da Epifania: p. 611.
} 
Ao contrapor a imagem dos pagãos do Oriente aos pagãos brasis, Vieira deixa claro que a pobreza analisada é aquela de carência de bens materiais. Assim, observa no índio os mesmos sintomas de pobreza analisados no Sermão das Obras de Misericórdia. Entretanto seu discurso não deixa dúvidas: a pobreza do índio supera a pobreza daquele que tem Cristo sob suas espécies. A pobreza do índio não é bem-aventurada e, assim, não está prescrita pelas Escrituras. Percebe-se, aqui, a necessidade de relativizar a Cristandade, ideia clara no discurso de Vieira quando chama a atenção à nobreza portuguesa de que não pode "haver Cristandade nem Cristandades nas Conquistas, sem os Ministros do Evangelho terem abertos e livres os dois caminhos", um da adoração e outro da proteção, como ocorreu aos Magos do Oriente. ${ }^{106}$

No que concerne à nova Cristandade que se gestou no Brasil, inclusive no século de Vieira, é fácil identificar a maneira como ela se formou segundo a urgência da colonização e da necessidade de mão-de-obra. Nesse contexto, os jesuítas deviam produzir cristãos em série, independentemente de sua qualidade, como escreve o jesuíta em Carta sobre os índios do Maranhão:

"E ali, postos os índios de um lado da lgreja e as índias do outro, Ihes faz o padre a doutrina, ensinando-Ihes primeiro as orações do catecismo, e depois declarando-Ihes os mistérios da fé, perguntando e premiando os que melhor respondem. $E$ porque esta gente pela maior parte está muito inculta, e os que

\footnotetext{
${ }^{106}$ Idem: p. 613.
} 
sabem alguma coisa são as orações, que eles não entendem; não sendo capazes de catecismo tão dilatado e miúdo como é o geral." 107

Se os nativos que conviviam com os jesuítas sofriam de toda essa carência espiritual, os residentes nas casas dos portugueses atravessavam sua vida na mais absoluta treva espiritual, visto que

"Muitos deles vivem e morrem pagãos, sem seus senhores nem párocos Ihes procurarem batismo, nem fazerem escrúpulo disso. Os que têm nome e batismo de cristãos, muitos 0 receberam sem saberem o que recebiam, e vivem tão gentios como de antes eram, sendo muito raros, ainda dos mais ladinos, os que se desobrigam pela Quaresma; e há cristãos de sessenta anos que nunca se confessaram."108

Todavia, o estado de "sub-cristandade" não estava restrito aos nativos. Na mesma carta, Vieira descreve a situação espiritual dos portugueses residentes no Maranhão:

"Os portugueses, Senhor, vivem nestas partes em necessidade espiritual pouco menos que extrema, com grande falta de doutrina e sacramentos, havendo muitos deles que não ouvem missa nem pregação em todo o ano pela não terem, nem sabem os dias santos para os guardarem, nem os

${ }_{107}^{107}$ Carta ao Provincial do Brasil, 22 de maio de 1653: p. 115.

${ }^{108}$ Carta ao Rei D. João IV, 20 de maio de 1653: p. 84. 
guardam, ainda que os saibam, nem há quem a isso os obrigue; o qual desamparo é ainda maior nas mulheres, filhos e filhas, morrendo não poucas vezes uns e outros sem confissão."

Surge assim, no seio da Igreja, uma nova versão da Cristandade, fruto das Conquistas e da necessidade de dilatação do Catolicismo a qualquer custo. Uma Cristandade efêmera, vaporizada nas selvas, aspirada nas choupanas e desdenhada nos engenhos de açúcar. Não obstante o Catolicismo cultivado por Vieira no Novo Mundo ser tão distinto daquele estabelecido na Europa, o inaciano demonstra grande preocupação com esse trabalho, principalmente quando empreende a conquista espiritual nos territórios ao Norte, de onde foi expulso por tentar normatizar os descimentos conforme os editos do Rei.

Estão claras no Sermão da Epifania a autoridade e a influência de Vieira no seio da Casa de Bragança, tanto que é muito comum vê-lo reportar-se às autoridades reais de Portugal com notável desenvoltura e familiaridade. $\mathrm{O}$ sermão em questão veio a público em 1662, quando pregado na Capela Real e dirigido à Rainha Regente. Entre os fatos que envolveram a pregação desse sermão, vale ressaltar que sua prédica se deu quando os jesuítas, expulsos do Maranhão, como supradito, voltam a Lisboa. Na ocasião, Vieira aproveita a oportunidade para explicar e justificar 0 incidente, rogando à Rainha que interfira nas missões daquele território que,

$\overline{{ }^{109} \text { Carta ao Rei D. João IV de } 20}$ de maio de 1653: p. 84. 
embora também fosse possessão portuguesa, não era parte do Brasil, mas compunha uma província chamada Maranhão e GrãPará.

Cinco anos antes do grande conflito pela posse do índio, o que culminou na malfadada partida dos jesuítas para Portugal, Vieira predica, na Igreja da Companhia, no Maranhão, o belíssimo Sermão do Espírito Santo. Naquele momento partiam os inacianos para a conquista de nações indígenas pelo Rio Amazonas. As expectativas eram muito grandes, principalmente pela certeza das grandes dificuldades que enfrentariam na semeadura do Evangelho, sendo a maior delas, segundo Vieira, a grande variedade de línguas, os diferentes falares das nações indígenas.

Coincidentemente, nos dois sermões percebem-se a degradação constante da natureza indígena e a carência total de traços de humanidade, quem sabe como única maneira de supervalorizar seu trabalho e reforçar a necessidade da tutela.

Amparado na doutrina da Trindade, Vieira evidencia a ação do Espírito Santo para a conversão das nações bárbaras. Traça analogia com o acontecimento bíblico relatado nos Atos dos Apóstolos no dia de Pentecostes quando, reunidos todos no cenáculo de Jerusalém, judeus convertidos falaram diferentes línguas, todos ao mesmo tempo. No mesmo dia, ao ouvir o sermão de Pedro, três mil pessoas se converteram à doutrina de Cristo, transmitida pelos apóstolos.

Vieira também contava com o Espírito Santo para aprender tão rapidamente as línguas dos índios, porque estavam em missão 
"dificultosíssima (que) é pregar a gentes não de uma só nação e uma só língua diferente, senão de muitas e diferentes nações e muitas e diferentes línguas desconhecidas, escuras, bárbaras e que se não podem entender."110

Considerando, porém, que as línguas faladas pelos que estavam no Cenáculo eram línguas de povos civilizados, Vieira e seus companheiros de missão encontravam-se em situação bem mais desfavorecida. Segundo o autor, os falares indígenas comportavam sons que dificultavam ainda mais sua compreensão. Muitas vezes os sons ininteligíveis precisavam ser deduzidos pela argúcia dos padres. Realiza ali o autor uma interessante análise acerca da fonética das línguas nativas:

"Por vezes me aconteceu estar com o ouvido aplicado à boca do bárbaro, e ainda do intérprete, sem poder distinguir as sílabas, nem perceber as vogais, ou consoantes, de que se formavam, equivocando-se a mesma letra com duas ou três semelhanças, ou compondo-se (o que é mais certo) com mistura de todas elas: umas tão delgadas e sutis, outras tão duras e escabrosas, outras tão interiores e escuras, e mais afogadas na garganta, que pronunciadas na língua: outras tão curtas e subidas, outras tão estendidas e multiplicadas, que não percebem os ouvidos mais que a confusão, sendo certo em todo rigor que as tais línguas não se ouvem, pois se não

\footnotetext{
${ }^{110}$ Sermão do Espírito Santo: p. 427.
} 
ouve delas mais que o sonido, e não palavras desarticuladas e humanas." 111

Embora essas observações tenham-se feito necessárias para ajudar a compor a visão de Vieira em relação aos índios, complementando a descrição que aquele faz do caráter destes, nosso real interesse é investigar a maneira como o jesuíta identifica a pobreza no índio. Porém, antes da análise minuciosa da pessoa do índio, achamos conveniente observar a maneira como Vieira retrata a terra do Brasil.

\section{Novo Mundo - Paraíso infernal}

Antes de se buscar qualquer referência nos sermões ou em qualquer outro escrito de Vieira, sabe-se que é fato notório que o Brasil era representado no universo católico, principalmente, no século XVII, em plena Contrarreforma, como lugar distante da Cristandade europeia. Quando se estudam a documentação e os registros dos viajantes do século $\mathrm{XVI}$, nota-se o grande desprezo que o europeu cultivava pelo Brasil. Os escritos de Anchieta são abundantes em referências negativas a respeito das matas, do clima, dos animais do país. Os elementos nativos são constantemente demonizados e depreciados, não porque, quiçá, fossem realmente ruins, mas por não serem europeus. Analisando-se os escritores coevos, percebe-se sua desilusão por o nome Brasil prevalecer

\footnotetext{
${ }^{111}$ Idem. pp. 428/429.
} 
sobre os outros nomes cristãos que se tentaram atribuir a esta terra. A terra do Brasil, aquela ilha presente nos mapas medievais, ou a bela praia do Novo Mundo encontrada pelos portugueses, abundante em madeira, jamais se poderia chamar Ilha de Vera Cruz ou Terra de Santa Cruz.

Tendo esse mesmo pensamento, Vieira traça um retrato lúgubre da nova província ocupada por Portugal, com cores impiedosas, embora inicie o Sermão da Epifania fazendo analogia entre esta e a nova terra prometida nas profecias de Isaías:

"Uma das coisas mais notáveis que Deus revelou e prometeu antigamente, foi que ainda havia de criar um novo céu e uma nova terra. (...) Logo, que terra nova e Céus novos são estes, que Deus tanto tempo prometeu que havia de criar? (...) Eu, seguindo o que ela simplesmente soa e significa, digo que esta nova terra e estes novos Céus são a terra e os Céus do Novo Mundo descoberto pelos portugueses." 112

E pelo encontro desta nova terra porfiaram os portugueses nos mares bravios e, vencendo-os, revelaram "as gentes, as terras, 0 mundo que as mesmas águas encobriam". Envoltos em trevas, os elementos desse novo cosmo logo são iluminados pela luz do Evangelho trazido pelos lusos. Desse início heroico, Vieira parte para observações mais ligadas às ocorrências de seu tempo:

\footnotetext{
${ }^{112}$ Epifania:p. 596.
} 
"Mas quem dissera ou imaginara que os tempos e os costumes se haviam de trocar, e fazer tal mudança que esta mesma glória nossa se visse entre nós eclipsada, e por nós escurecida?"113

Era inadmissível ao pregador a condição vivida por ele e seus companheiros no momento da pregação do Sermão. Tinham sido expulsos do Maranhão, impedidos de pregar o Evangelho, sua luz fora banida e desprezada. Sua razão de ser e viver perdera-se, a nos basearmos nos questionamentos que se seguem:

"Quem imaginara, torno a dizer, que aquela glória tão heroicamente adquirida nas três partes do mundo, e tão celebrada e esclarecida em todas as quatro, se havia de escurecer e profanar em um Rincão ou Arrabalde da América?!"114

A terra era, de tal forma, amaldiçoada que os próprios cristãos, estando nela, esquecem seu propósito primeiro, estando envoltos pelas trevas e combatendo as estrelas que trazem a Boa Nova da salvação para os gentios. Tentam dissipar a luz com a força da cobiça. É terra corrupta e, uma vez nela, qualquer cristão desavisado deixa-se levar pelas suas concupiscências. Eram apenas quatro choupanas com o nome de Belém, onde o demônio encontrou guarida e força para transformá-la em "pátria do Anticristo". O

\footnotetext{
113 Idem: p. 599.

114 Sermão da Epifania: p. 599.
} 
monstro apocalíptico que emergiu do mar surgiu "daquelas brenhas" do Maranhão, última conquista portuguesa na América. Em companhia de assassinos degredados, as estrelas jesuíticas desbravaram "sertões habitados por feras, minados de bichos venenosos, nos climas mais nocivos da Zona Tórrida".

As estrelas da Companhia de Jesus tentam iluminar o lugar "onde não são vistas, nem podem ser no lugar mais desluzido, e no canto mais escuro de todo o mundo". Se não bastassem as agressivas referências registradas no Sermão da Epifania, o Maranhão está predestinadamente escolhido para a perdição, pois, segundo Vieira no Sermão da Quinta Dominga da Quaresma, a letra que o "tocaria seria o próprio $M: M$ de murmurar, $M$ de motejar, $M$ de maldizer, $M$ de malsinar, $M$ de mexericar e, sobretudo, $M$ de mentir". Não podia ser diferente, porque

"O mesmo se passa nos vícios. Se o clima influi soberba, nasce a inveja: se influi gula, nasce a luxúria: se influi cobiça, nasce a avareza: se influi ira, nasce a vingança. $E$ para nascer a mentira, que é o que influi? Ociosidade. Onde o clima influi ócio, dá-se a mentira a perder. (...) Estes são os dois vícios do Maranhão, estas as duas influências deste clima, ócio e mentira." ${ }^{" 115}$

Além da análise agressiva, relativa aos moradores do Maranhão, na verdade brancos contaminados pelos maus ares da

\footnotetext{
${ }^{115}$ Sermão da Quinta Dominga da Quaresma: p. 521.
} 
terra, o desamor por tudo o que havia no Brasil transforma-se, para o orador, na tônica do seu Sermão. Com efeito, para quem circulou pelos ricos palácios da Europa, morar no Maranhão era como "esconder-se, porque não é só desterrar-se para sempre, mas enterrar-se". Contudo, a grande estrela da Companhia teve de contentar-se numa terra onde a Divina Providência é quem delibera sobre a vida ou a morte. Informa-nos Vieira em uma de suas cartas que

"Não corre nesta terra dinheiro, e as vendas se fazem por comutações, como na primeira idade do mundo; não há praça pública ou casas particulares, em que as coisas necessárias para a vida estejam expostas, com que vem a ser forçoso terem-nas todos de sua lavra, como verdadeiramente as têm: e como o tempo de nossa chegada é ainda tão pouco, que não basta para termos feito esta prevenção, são muitas as ocasiões que tivemos de experimentar como a Divina Providência, sem diligência alguma nossa, nos acode em todas, provendo-nos nos mesmos tempos e das mesmas coisas de que tínhamos necessidade, como se a mesma necessidade avisara ao piedosíssimo Senhor."116

Não há dúvida de que o retrato material do Maranhão não é dos mais animadores. Pela descrição de Vieira percebe-se que o

${ }^{116}$ Carta ao Provincial do Brasil, 22 de maio de 1653: p. 117. Quando analisamos concomitantemente Sermões e Cartas do autor, temos a intenção de revelar e confirmar exposições que unicamente nos Sermões poderiam não conferir a mesma credibilidade histórica. Mesmo sendo um trabalho literário, é extremamente compensador traçar analogias entre as representações dos Sermões e a realidade vivida pelo autor, no Maranhão do século XVII. 
modus vivendi de seus moradores projetava-se de maneira bastante primitiva, tornando a vida muito mais insegura e dificultosa. Porém, não se deve esquecer que as observações são feitas por um homem acostumado às grandes metrópoles europeias, o que torna ainda mais soturna a pintura do Novo Mundo português. Nota-se, aqui, que a situação de pobreza e carência acomete a maioria dos moradores, sobretudo os brancos acostumados ao "conforto" de Portugal. No ano de 1653 não havia sequer uma casa de Misericórdia que socorresse os doentes do lugar, como descreve Vieira:

"Com as coisas da botica, se trouxéramos muito, se poderia exercer bem a caridade, porque é a terra muito falta de medicamentos, como de médicos, que não há."117

Não havia pedintes, porque não havia onde pedir. Existiam as pobrezas ocultas, as misérias que causam vergonha que, por isso, só se revelavam nos confessionários.

Assim, diferente da Terra da Promissão para onde a Estrela de Belém guiou os Magos do Oriente, terra amena e deliciosa, a terra para onde foram trazidos os jesuítas não é terra, mas um desterro, o avesso da terra, lugar ausente da terra, a representação mais nítida da ausência, o depósito de todas as carências, a origem de todas as pobrezas. $^{118}$

\footnotetext{
${ }_{117}^{117}$ Carta ao Provincial do Brasil, 22 de maio de 1653: pp. 116/117.

${ }^{118}$ Epifania: p. 607.
} 


\section{Pobre índio pobre}

Se a terra do Maranhão não escapou da pena implacável de Vieira, o índio, em seus sermões, sofreria suas mais profundas cutiladas. Nos dois sermões ora em análise, fica clara a imagem representativa do índio para o jesuíta. É interessante observar que a primeira dificuldade arrolada por Vieira para o trabalho missionário é a "qualidade da gente; porque a gente destas terras é a mais bruta, a mais ingrata, a mais inconstante, a mais avessa, a mais trabalhosa de ensinar de quantas há no mundo."119

Há, na segunda parte do Sermão do Espírito Santo, uma comparação dos rebanhos confiados a Pedro com aqueles confiados aos jesuítas. Se, para Pedro, foi necessário muito amor na conversão daqueles gentios, "que será para tirar das brenhas ovelhas feras, para as amansar e afeiçoar aos novos pastos, para as acostumar à voz do pastor, e à obediência ao cajado?". As ovelhas apascentadas por Pedro comem nos prados e bebem nos rios; as ovelhas tangidas pelos jesuítas comem a carne do pastor e bebem seu sangue.

O discurso concernente ao índio toca os limites da retórica barroca no Sermão da Epifania:

"Se os gentios indômitos, se os tapuias bárbaros e feros daquelas brenhas se armarem medonhamente contra os que Ihe vão pregar a fé; se os cobrirem de setas, se os fizerem em

\footnotetext{
${ }^{119}$ Sermão do Espírito Santo: p. 422.
} 
pedaços, se Ihes arrancarem as entranhas palpitantes $e$ as lançarem no fogo, e as comerem; isto é o que eles já têm feito outras vezes, e o que lá vão buscar os que pelo salvar deixam tudo."120

A descrição acima apresentada, como pretexto para o autor se referir às perseguições dos colonos, evidencia enfaticamente a visão de Vieira em relação ao índio, principalmente àquele não cristianizado e que julgava ser objeto de seu trabalho missionário. Assim, o interlocutor do sermão é convencido de que os jesuítas enfrentaram maiores dificuldades que os apóstolos da Igreja Primitiva.

Outra análise a respeito do índio obriga o autor a retornar ao Velho Testamento, à história de José, vendido aos egípcios como escravo por seus irmãos. É interessante observar que, mesmo ao se referir positivamente ao índio, ele o faz de maneira a frisar a natureza irracional e indômita do nativo. A ocasião é dizer que o índio os considera muito mais que os colonos que são naturalmente cristãos. Mesmo assim,

"Estas aves de rapina que em vez de nos comerem nos sustentam como os corvos a Elias, estes os monstros (pela maior parte marinhos) que em vez de nos tragarem $e$ digerirem, nos metem dentro nas entranhas, e nelas nos conservam vivos como a Baleia a Jonas. $E$ se assim nos

\footnotetext{
${ }^{120}$ Sermão da Epifania: p. 603.
} 
tratam os Gentios e tais Gentios, quando assim nos tratam os Cristãos e Cristãos da nossa Nação e do nosso sangue: quem se não assombra de uma tão grande diferença?"121

A constante zoomorfização do nativo denuncia a perspectiva pela qual o autor analisava as nações recém-descobertas. Não importavam as boas ações realizadas pelo indígena após o processo de domesticação e cristianização. A Cristandade da qual ele fazia parte era relativa e estava distante daquela composta pelos homens do mesmo sangue e da mesma nação de Vieira.

Por meio do discurso, Vieira imprime na alma do índio a miséria vislumbrada por sua perspectiva europeia:

"As nossas Estrelas fazem as suas missões entre as pobrezas e os desamparos, entre os ascos e as misérias da gente mais inculta, da gente mais pobre, da gente mais vil, da gente menos gente de quantas já nasceram no mundo."122

É claro que, dentre as pobrezas descritas pelo autor, está evidente a pobreza de bens materiais, como já foi citado acima. Contudo, não se pode esquecer o juízo unilateral inerente ao jesuíta. Riqueza para ele tinha característica bem definida: fartura de alimentos, de vestidos, de casas bem fornidas, poder temporal e letramento. Era como se definia a nobreza no Brasil colônia. Condição difícil e praticamente impossível de ser alcançada por um

\footnotetext{
21 Sermão da Epifania: p. 604.

122 Sermão da Epifania: p. 611.
} 
nativo ou por seus descendentes, principalmente porque a honradez na Colônia ainda passava pelo crivo da cor, como registra Nizza da Silva $^{123}$. O índio era o negro da terra e, além disso, era

\begin{abstract}
"Uma gente com quem a natureza meteu tão pouco cabedal, com quem se empenhou tão pouco a arte e a fortuna, que uma árvore lhe dá o vestido e o sustento, e as armas, e a casa, e a embarcação. Com as folhas se cobrem, com o fruto se sustentam, com os ramos se armam, com o tronco se abrigam, e sobre a casca navegam. Estas são todas as alfaias daquela pobríssima gente."124
\end{abstract}

Se não bastasse o pouco trabalho dispensado pela natureza na formação do índio, o que determina sua maneira de viver, há no nativo descrito por Vieira uma carência impregnada e tão própria dele que nada podem esperar os inacianos quando se dispõem a evangelizar tais seres. É necessário o espírito de Cristo quando alguém decide lavrar essa "vinha estéril": "porque pregar 0 Evangelho aos pobres, aos miseráveis, aos que não têm nada no mundo, é ação tão própria do espírito de Cristo".

Essa eloquente afirmação não ocorre com o mínimo propósito dele em se defender diante da Rainha Regente e pedir providências

\footnotetext{
${ }^{123}$ A autora registra a observação do historiador Domingos Loreto Couto ao escrever em relação a divisão estamental em Pernambuco: "Não é fácil determinar nestas províncias quais sejam os homens da plebe, porque todo aquele que é branco na cor, entende estar fora da esfera vulgar. Na sua opinião, o mesmo é ser alvo que ser nobre, nem porque exercitam ofícios mecânicos perdem essa presunção."(BMP, Cod. 235, f.192, liv. III, parágrafo 167, 1904)

124 Epifania: p. 611.
} 
relativas à situação provocada pelos colonos. Observa-se que a insistência do autor em evidenciar com letras garrafais a pobreza dos índios deve-se, principalmente, às acusações assacadas pelos senhores de terra, que tinham interesse na mão-de-obra deles e consideravam os jesuítas o grande empecilho para a realização de seus projetos. Afortunadamente, essas acusações são minuciosamente descritas por Vieira:

"Dizem que o chamado zelo com que defendemos os índios é interesseiro e injusto: interesseiro porque os defendemos para que nos sirvam a nós: e injusto, porque defendemos que sirvam ao povo. Provam o primeiro e cuidam que com evidência, porque veem que nas aldeias edificamos as Igrejas com os índios, veem que pelos rios navegamos em canoas equipadas de índios: veem que nas missões por água e por terra nos acompanham e conduzem os índios: logo defendemos e queremos os índios para que nos sirvam a nós!"125

Entretanto, se as acusações são implacáveis, os argumentos do jesuíta em sua defesa retumbam nas palavras em prol da Coroa e da lgreja:

"Se imos em Missões mais largas a reduzir e descer Gentios, ou a pé, e muitas vezes, descalços, ou embarcados em

${ }^{25}$ Epifania: p. 618. 
grandes tropas à ida, e muito maiores à vinda, eles e nós imos em serviço da Fé e da República, para que tenha mais súditos a Igreja e mais vassalos a Coroa: e nem os que levamos, nem os que trazemos servem a nós, senão nós a uns e outros, e ao Rei e a Cristo."

Não há, segundo Vieira, qualquer interesse em se aproveitar da mão-de-obra indígena por parte dos jesuítas "porque todos os nossos haveres eles os têm em seu poder". Por outro lado, aqueles que os acusaram apropriaram-se de suas choupanas e "acharam ouro e prata; mas só a dos cálices e custódias". E, nos guardaroupas, a pobreza material a que estavam submetidos os inacianos: “...sotainas remendadas eram de algodão grosseiro, tinto na lama, como calçado de peles de veado e porco-montês, que são as mesmas galas com aqui aparecemos".

O desterro do mundo, segundo o autor, é também o reino da pobreza onde a sobrevivência implicava luta feroz. Diferentemente do ocorrido aos Magos do Oriente, conduzidos pela estrela, que ao verem a pobreza do Presépio ofereceram presentes ao menino Jesus, a gente conduzida pelos jesuítas "é tão pobre e tão miserável que nem eles têm o que oferecer, nem nós temos que aceitar"127 conclui o autor.

Sermão da Epifania: p. 618.

27 Ibidem. 


\section{CAPÍTULO VI}

\section{SERMÃO DE SÃO ROQUE - QUANDO A POBREZA COMPROMETE A SOBERANIA}

O Sermão de São Roque, entre todos os sermões de Vieira, é o que mais evidencia a faceta racional do jesuíta, de maneira que, em certos pontos, contradiz as teses defendidas pelo autor em todos seus outros escritos. Redigido em 1644, exprime duas situações distintas e concomitantemente vividas por Portugal: uma, o nascimento do príncipe D. Afonso, de extrema felicidade; a segunda, a decadência econômica do Reino, motivo de grande preocupação, obrigando Vieira a sugerir a criação das companhias de comércio, à imitação das companhias holandesas.

Neste capítulo, procuramos analisar a segunda situação exposta no Sermão. Considerando a necessidade de abordar pontos importantes relativos à pobreza e à riqueza, fundamentadas na doutrina da misericórdia, veremos de que maneira Vieira sugere a solução para tal impasse. Com efeito, o fortalecimento econômico do Reino e sua inserção na modernidade mercantil, a fim de fazer frente ao poderio holandês, tornava-se, a cada dia, o único caminho a ser seguido por Portugal.

O enfraquecimento das fronteiras comerciais pelo domínio dos mares pelos batavos obrigou o Rei a pensar numa maneira de reaver a supremacia das rotas, tanto para as Índias quanto para o Novo Mundo. Ninguém poderia, naquele momento, de maneira tão eficaz, 
aconselhar o soberano português quanto o padre jesuíta Antônio Vieira.

Conhecedor das cortes europeias, tanto católicas quanto protestantes, Vieira alerta o Rei quanto ao perigo que passava todo 0 Reino e aconselha a abertura imediata das companhias de comércio. Como excelente articulador político e econômico e notável diplomata, detecta imediatamente a escassa liquidez em que se encontravam os cofres de Portugal. Apesar da felicidade pelo nascimento de um novo herdeiro, o Reino, segundo Vieira, está por se perder. Em outras palavras, Portugal vive um momento de extrema precariedade econômica. Portugal está pobre.

Diante da situação, o jesuíta não analisa simplesmente o problema, mas já indica uma porta aberta para sua solução. Segundo ele, os remédios para a economia da Coroa existem, embora representem, para muitos, mais perigos que dispositivos de cura:

"Os remédios, dizem, supõem perigos, os perigos causam temores, os temores argúem desconfianças, e ânimos desconfiados, nem são bens, nem são ânimos. Ora o nosso Evangelho, quando menos, não discorre assim; dos mesmos princípios tira mais honradas consequências. Todo Evangelho que hoje nos propõe a lgreja, está fundado em temores, e em esperanças: porque, como trata da salvação, que é incerta, a esperança anima, o temor acautela. Mas ainda que estes dois afetos são necessários para obrar ao futuro."128

\footnotetext{
${ }^{128}$ Sermão de São Roque: p. 397.
} 
Com essa proposição, Vieira estava prestes a pisar um terreno perigoso. O que ele tinha em mente era nada menos que um acordo com os mercadores judeus, a fim de obter liquidez para a formação das companhias de comércio. A temeridade do jesuíta, embora acolhida pelo Rei, provocava desconfiança na nobreza portuguesa e despertava os sentidos da Inquisição para ele.

A fim de defender sua proposta, o jesuíta profere um dos discursos mais arriscados de sua vida. Inicia, contando a história de vida de São Roque e a maneira como foi rejeitado por aqueles que deviam apoiá-lo. As palavras de Vieira, como as do santo, traduzem uma ousadia repudiada pelos senhores do poder material, assim como do espiritual. O pregador tinha consciência dos perigos que existiam no empreendimento das companhias. Mesmo assim, usa sua impecável oratória para defender sua ideia, dizendo que

"O remédio temido, ou chamado perigoso, são as duas Companhias mercantis. Oriental uma, e outra Ocidental, cujas rotas poderosamente armadas tragam seguras contra a Holanda as drogas da Índia e do Brasil. E Portugal com as mesmas drogas tenha todos os anos os cabedais necessários para sustentar a guerra interior de Castela."129

Os temores de Vieira encontram respaldo nos escritos históricos. Segundo Caio Prado Júnior, a partir da segunda metade do século XVII, Portugal experimentou um agudo empobrecimento

\footnotetext{
${ }^{129}$ Sermão de São Roque: p. 401.
} 
provocado pela restrição ao comércio asiático, dominado pelos holandeses. Nesse momento, a Colônia transformou-se em rota de fuga para aqueles que buscavam a prosperidade. Essa descontrolada afluência provocou conflitos entre os portugueses aqui estabelecidos e os adventícios, que procuravam, a qualquer custo, desalojar aqueles de suas confortáveis posições junto à Coroa. ${ }^{130}$

Ainda, conforme Prado, a primeira iniciativa contra 0 contrabando e a sangria de produtos brasileiros foi a proibição a qualquer navio de viajar isoladamente. O comércio entre a Metrópole e a Colônia só era permitido com a circulação dos navios em comboio. A seguir, vêm as companhias de comércio:

"Já adotadas por ingleses e holandeses em suas possessões, consistia em reservar a certas pessoas o direito exclusivo de realizar o comércio em toda a extensão da costa desde o Rio Grande do Norte até São Vicente."131

Essas pessoas privilegiadas, na verdade judeus, são citadas por Vieira de maneira sutil. Fica, entretanto, clara a rejeição da nação portuguesa dos financiadores desse projeto, visto que, "a mistura do dinheiro menos cristão com o católico faz suspeitoso todo o mesmo remédio e, por isso, perigoso". ${ }^{132}$

Os argumentos de Vieira são surpreendentes: tomando o exemplo de São Roque, que repartiu toda sua riqueza com os

\footnotetext{
${ }^{130}$ História Econômica do Brasil: p. 50.

131 História Econômica do Brasil: p. 53.

132 Sermão de São Roque: p. 401.
} 
pobres, mostra que "as armas com que o mundo faz maior guerra contra os homens, são as riquezas". Assim, nada mais providente que dissolver essa riqueza a fim de preservar a paz. Outra metáfora usada pelo autor é aquela de Davi quando se apossa dos despojos da guerra contra os pagãos e com o ouro manda que lhe façam uma coroa. Ora, segundo o autor, é a idolatria sendo tomada como instrumento de dilatação da fé, mesmo porque "servir à fé com as armas da infidelidade, oh que política tão cristã! Alcançar a Fé as vitórias, e pagar a infidelidade os soldos, oh que Cristandade tão política! ${ }^{133}$

Considerando-se que esse Sermão foi pregado na Capela Real, entende-se por que Vieira lança mão de tantos argumentos. $\mathrm{Na}$ verdade, ele estava instalado num verdadeiro "covil de lobos", a tratar de assunto tão delicado, num momento pouco propício para os outros, mas perfeito para ele. Sua intenção era que a Nobreza entendesse a necessidade do Reino e acatasse sua proposta de fundar as companhias mercantis com dinheiro judeu, assim como todas as outras nações "mais políticas" da Europa faziam.

Em momento crucial para a nação portuguesa, na iminência de ser novamente dominada, não há, para Vieira, problema nenhum na origem do ouro que serve para restaurar os reinos cristãos e dilatar a fé. Percebe-se que os argumentos do jesuíta são tecidos dentro das Escrituras e envoltos pela doutrina católica. Assim,

\footnotetext{
${ }^{133}$ Idem: p. 402.
} 
"Manda Deus ao primeiro Rei de Portugal que componha as armas de Portugal das Chagas de Cristo, e mais do dinheiro de Judas; para que entendamos que o dinheiro de Judas cristãmente aplicado, nem descompõe as Chagas de Cristo, nem descompõe as armas de Portugal."134

É importante analisar como a pobreza adquire um aspecto mais amplo e coletivo. As consequências dessa pobreza não atingem apenas aquele desafortunado do Sermão das Obras de Misericórdia, mas comprometem todo o Reino e expõem ao risco a Nobreza, tão acostumada à comodidade e ao luxo.

${ }^{134}$ Sermão de São Roque: p. 403. 


\section{CONCLUSÃO}

As ramificações do tema da pobreza em Vieira obrigaram-nos a empreender um percurso antes inimaginável. O que parecia, a princípio, simples e estanque, expandiu-se, apontando inúmeras direções e diferentes possibilidades. O resultado dessa jornada foi apenas o princípio de um entendimento mais sólido e mais consciente a respeito da concepção de pobreza no século XVII e suas implicações na formação da sociedade portuguesa.

Não nos foi possível estudar apenas o pobre representado no Sermão das Obras de Misericórdia, pois era apenas uma representação de uma sociedade transcendente exposta pelo discurso de Vieira. Tivemos que romper as fronteiras étnicas para descobrir quem podia ser nobre em Portugal e no Brasil. Encontramos, além dessas divisas, o índio a agonizar em sua condição de tutela e infância civilizacional, o que nos fez imaginar para ele uma perspectiva futura de pobreza e ignorância. Dialogamos também com o escravo africano por meio do Sermão XIV do Rosário e foi-nos possível mensurar o despojamento pelo qual passou a figura do negro, tanto na representação produzida pelo sermão quanto na realidade. O caminho percorrido, da África ao engenho de açúcar, revelou-se muito claro, ou melhor, escuro, denso e soturno quanto ao dia da crucificação de Cristo. O cativeiro estigmatizou para sempre os descendentes de Cam e lançou-os eternamente às margens do Novo Mundo. O óbolo da cristianização 
pago com honradez e piedade produziu apenas gente que "tão humilde figura faz no mundo e na estimação dos homens".

O Sermão de Santo Antônio ajudou-nos a entender a concepção da estrutura social segundo Vieira, os três estados devidamente vincados e separados pelo privilégio e pela obrigação. Em Portugal, as prerrogativas dos dois primeiros estados, nobreza e clero, obrigaram Vieira a romper as fronteiras da tradição e sugerir a tributação dessas duas classes parasitárias. No Brasil, a dificuldade em se definir quem era pobre impulsionou-nos a buscar historiadores como Nizza da Silva e Mary Del Priore. Mergulhamos nas intimidades das estruturas sociais da Colônia e vimos reveladas as disputas pelos títulos de nobreza como um dos principais meios, buscados pelos colonos de emergir da profunda miséria do "desterro" que era o Brasil. A segunda autora nos conduziu à análise das relações amorosas e das consequências das procriações irresponsáveis que surgem como um forte dado de perpetuação da pobreza e da indigência. A bastardia evidenciou-se como um trauma profundamente arraigado na cultura brasileira e que deve ser analisado como fator importante em nossa formação social.

Seria interessante permanecer na transcendência do discurso de Vieira e entender sua justificação da pobreza apenas pelo lado dogmático. Todavia, ficou claro que o próprio Vieira passeia pela terra com a mesma desenvoltura com que passeia pelo céu.

O Sermão de São Roque apresentou-nos o jesuíta na sua surpreendente racionalidade, a propor a fundação das Companhias de Comércio com investimento dos mercadores judeus. A pobreza 
para o Reino não era bem-aventurada, pois comprometia a soberania e supremacia do Rei. A misericórdia desaparece e dá lugar a pensamentos práticos, totalmente em consonância com as exigências comerciais da época.

Logo, nota-se que a pobreza no Sermão das Obras de Misericórdia pode ser justificada mediante uma promessa escatológica, a da herança do Reino dos Céus e o privilégio de se ter Cristo sob suas espécies. Já a pobreza no Sermão da Visitação de Maria também se justifica porque, pela doação do óbolo ao soldado doente, Deus confere a vitória a seu povo. No Sermão XIV do Rosário, a miséria do cativeiro negro é justificada pelo contato do africano com o Evangelho de Cristo. Nos sermões da Epifania e do Espírito Santo a imagem do índio "boçal" e inconstante justifica sua posição aos pés do jesuíta. Sua pouca razão conduziu-o aos recônditos da estrutura social que se plasmou na Colônia; sua presença nos rincões do Brasil contou com a companhia dos mestiços de todas as tonalidades e combinações e, juntos, aceitaram devotamente a Cristo sob suas espécies.

Assim, o óbolo não cessa, sempre há de soar no fundo do prato o som mudo da expressão da misericórdia, que hoje, nada mais é que um dado cultural.

Vieira só não encontra justificativa para a pobreza do Reino. Ao contrário, cria projetos temerários, sugere acordos suspeitos aos olhos da Inquisição, o que the vale dois anos na prisão, muitas humilhações, a condenação ao silêncio e ao degredo. 
$\mathrm{Na}$ força de sua singular erudição, por meio de seu discurso persuasivo, Vieira cria duas esferas de concepção sobre a pobreza. Uma, a do pobre historicamente definido, transcendente no seu lugar eterno, cuja vitima é apenas o homem. A outra, que deve ser aplacada e combatida, independentemente das armas escolhidas, que é a pobreza do Reino, que ameaça a soberania e a liberdade de toda uma nação. Apesar de tudo, ficamos com a sonora expressão dos evangelhos: "Beati pauperes; Beati misericordes".

A concepção de pobreza nos escritos de Vieira muda conforme o objeto. Embora use sempre os mesmos termos ao se referir ao branco, ao negro e ao índio, é nítida a diferenciação da miséria que envolve cada um deles. Percebe-se que, diante das circunstâncias, a pobreza assume contornos distintos em seu discurso. No entanto, em todos os casos, a miséria é devidamente justificada: a pobreza do branco é bem-aventurada porque Cristo reside sob suas espécies; a pobreza do negro é justificada porque possibilita seu encontro com o Cristianismo, a pobreza do índio é inata em virtude de sua eterna infância civilizacional. E é desta maneira que o nativo do Novo Mundo será descrito e analisado nos seus sermões. 


\section{APÊNDICE}

\section{CRONOLOGIA DE ANTÔNIO VIEIRA}

1608 - Nasce em Lisboa, numa segunda-feira, 6 de fevereiro, primogênito dos seis filhos de Cristóvão Vieira Ravasco e Maria de Azevedo.

1614 - Partida para a Bahia com a família

1623 - Entra no noviciado da Companhia de Jesus.

1624 - A esquadra holandesa de Jakob Willekens conquista a Cidade de Salvador.

1625 - Emite votos do primeiro biênio, após o noviciado. Expulsão dos holandeses.

1626 - Redige em latim a "Carta Ânua ao Geral dos Jesuítas em Roma", dando conta dos acontecimentos dos dois últimos anos; transfere-se para o Colégio dos Jesuítas de Olinda, onde é encarregado de ministrar aulas de Retórica.

1629 - Volta à Bahia para complementação dos estudos de Filosofia e Teologia.

1634 - Recebe as ordens sacerdotais.

1635 - É encarregado da cadeira de Teologia do Colégio da Bahia.

1640 - Aclamação de D. João IV e fim da Monarquia Dual.

1641 - Partida de Vieira para Lisboa em Companhia de D. Fernando de Mascarenhas, filho do Vice-Rei do Brasil, a fim de jurar obediência ao novo rei de Portugal. 
1642 - Prega o primeiro sermão em Portugal (Sermão dos Bons Anos).

1643 - Redige a "Proposta" a D. João IV, em que analisa o "miserável estado do reino e a necessidade que tinha de admitir os judeus mercadores".

1644 - É nomeado Pregador-Régio.

1646 - Início das missões diplomáticas. Viaja à Holanda e redige a "Proposta a favor da gente da nação".

1647 - Redige o "Parecer sobre a compra de Pernambuco aos Holandeses".

1648 - Retorno a Portugal, onde redige o "Papel a favor da entrega de Pernambuco aos holandeses", conhecido como "Papel Forte".

1649 - Primeiras denúncias no Santo Ofício. Carta do Geral para expulsar Vieira da Companhia de Jesus.

1650 - Outras denúncias no Santo Ofício

1652 - Partida para o Maranhão

1653 - É nomeado superior das missões jesuíticas do Maranhão e Pará.

1654 - Informa ao padre Provincial do Brasil as condições desastrosas em que se faziam as entradas e os resgates.

1655 - Redige o "Parecer sobre a conversão e governo dos índios e gentios". Volta ao Maranhão.

1656: Nova denúncia no Santo Ofício. Morte de D. João IV; regência de D. Luísa de Gusmão.

1658 - É nomeado visitador. 
1659 - Entrada pelo Rio Tapajós; entrada para a llha de Joanes (Marajó)

1660 - André Fernandes é intimado a entregar escrito no Santo Ofício. Primeiro parecer sobre o processo inquisitorial de Vieira, favorável à sua prisão.

1661 - Revolta dos moradores do Maranhão e Pará contra os jesuítas

1662 - Vieira redige a "Resposta aos vinte e cinco capítulos" de acusação contra si e os jesuítas do Maranhão e Grão-Pará.

1663 - Desterro para Coimbra por solicitação do Santo Ofício. É retido na casa da Companhia de Jesus, naquela cidade.

1665 - Confisco dos rascunhos de sua defesa dos pontos censurados pelo Tribunal.

1666 - Entrega as duas Representações da Defesa perante o Tribunal do Santo Ofício.

1667 - No dia 23 de dezembro é proferida no Santo Ofício de Coimbra, por duas horas e quinze minutos, a sentença condenatória de Vieira.

1668 - É transferido para o noviciado da Companhia de Jesus em Lisboa.

1669 - Partida para Roma, em busca de revisão de sua sentença.

1672 - Prega possivelmente seu primeiro sermão em italiano (Sermão de São Francisco).

1673 - Primeiro sermão para a Rainha Cristina da Suécia (Quinta terça-feira da Quaresma) 
1674 - Breve pontifício, suspendendo o Tribunal do Santo Ofício português

1675 - Breve pontifício, absolvendo Vieira das penas passadas e isentando-o para sempre da jurisdição inquisitorial portuguesa.

1678 - Escreve o "Memorial ao Príncipe Regente D. Pedro II".

1679 - Sai à luz o primeiro tomo dos Sermões.

1680-1 - Participação na junta de conselheiros de Estado e Ultramarinos para estabelecimento de plano de administração temporal e espiritual do Maranhão

1681 - Partida para a Bahia

1682 - Carta ao Marquês de Gouveia, comentando a sua queima em estátua nas comemorações de Coimbra

1683 - Assassinato do alcaide da cidade de Coimbra por mascarados

1688 - Vieira é nomeado visitador do Brasil e do Maranhão.

1689 - Morte da Rainha Cristina

1691 - Fim do triênio como visitador

1694 - Manifesta o seu "Voto sobre as dúvidas dos moradores de São Paulo", contrário ao sistema de "repartimentos" de índios pretendidos pelos bandeirantes.

1697 - Envia o décimo segundo tomo dos Sermões. Possivelmente, a dez de julho dita sua última carta. Morre em 18 de julho do mesmo ano, com 89 anos e 5 meses, sem chegar a ver a carta do Geral que suspendia a privação de voz passiva e ativa que sofrera. 


\section{BIBLIOGRAFIA}

ASSUMPÇÃO, Tomás Lino de. História Geral dos Jesuítas. Lisboa, Editora Moraes, 1982.

BANZA, Ana Paula. Defesa perante o Tribunal do Santo Ofício. Lisboa, Imprensa Nacional / Casa da Moeda, 2008.

BÍBLIA SAGRADA. (Tradução da Vulgata pelo Pe. Matos Soares). São Paulo, Edições Paulinas, 1982.

BOSI, Alfredo. Dialética da Colonização. São Paulo, Companhia das Letras, 1992.

CHAUÍ, Marilena. Brasil, mito fundador e sociedade autoritária. São Paulo, Editora Perseu Abramo, 2008.

CRESPIN, Jean. Tragédia da Guanabara - História dos primeiros mártires do Cristianismo no Brasil. Rio de Janeiro, CPAD, 2006.

CUNHA, Manuela Carneiro da (org.). História dos Índios no Brasil. São Paulo, Companhia das Letras, 2003.

EISENBERG, José. As Missões Jesuíticas e o Pensamento Moderno: Encontros Culturais e Aventuras Teóricas. Belo Horizonte, Editora da UFMG, 2000.

FOUCAULT, Michel. Vigiar e Punir. Petrópolis, Editora Vozes, 2000.

FURTADO, Celso. Formação Econômica do Brasil. São Paulo, Companhia Editora Nacional, 1989.

GEREMEK, Branislaw. A Piedade e a Forca - História da miséria e da caridade na Europa. Lisboa, Editora Terramar, 1987. 
HANSEN, João Adolfo. "Sistemas Doutrinários da representação nas obras de Vieira". In: Vieira, Vida e Palavra. São Paulo, Edições Loyola, 2008.

HAUBERT, Máxime. Índios e Jesuítas no tempo das Missões séculos XVII e XVIII. São Paulo, Companhia das Letras, 1998.

HENDERSON, John et al. Poor Women and Children in the European Past. Ed. New York, Routledge, 1994.

HESPANHA, António Manuel. As Vésperas do Leviathan Instituições e Poder Político em Portugal - Século XVII. Lisboa, Editora Almedina, 1994.

Cultura Jurídica Europeia - Síntese de um milênio.

Florianópolis, Editora Boiteux, 2005.

HOLANDA, Sérgio Buarque de. Raízes do Brasil. São Paulo, Companhia das Letras, 2004.

HOORNAERT, Eduardo. Formação do Catolicismo Brasileiro. - 1500 - 1800. Petrópolis, Editora Vozes, 1978.

LEITE, Serafim. História da Companhia de Jesus no Brasil. Rio de Janeiro, Portugália, 1938.

LISBOA, João Francisco. Vida do Padre Antonio Vieira. Rio de Janeiro, W. M. Jackson, s/d.

MOLLAT, Michel. Os Pobres na Idade Média (tradução de Heloisa John). Rio de Janeiro, Editora Campus, 1990.

NIZZA DA SILVA, Maria Beatriz. Ser nobre na Colônia. São Paulo, Editora da UNESP, 2005.

PÉCORA, Alcir. Máquina de Gêneros. São Paulo, EDUSP, 2001. Teatro do Sacramento. São Paulo, EDUSP, 2008. 
"O Bom Selvagem e o Boçal". In Vieira, Vida e Palavra. São Paulo, Editora Loyola, 2008.

PEREIRA, Rosemeire França de Assis Rodrigues. A Literatura de José de Anchieta e a Gênese da Educação Brasileira (dissertação de mestrado). São Paulo, FFLCH, USP, 2008.

PRADO, Caio Júnior. Formação do Brasil Contemporâneo: Colônia. São Paulo, Editora Brasiliense, 1994.

PRIORE, Mary Del. Ao Sul do Corpo, Condição Feminina, Maternidade e Mentalidades no Brasil Colônia. São Paulo, Editora da UNESP, 2008.

REDONDO, Augustin. Les Problèmes de L'exclusion em Espagne XVlème e XVIlème Siècles. Paris, Sorbonne, 1983.

RIBEIRO, Darcy. O Povo Brasileiro - A Formação e o sentido do Brasil. São Paulo, Companhia das Letras, 2001.

SERRÃO, Joaquim Veríssimo. Os tempos dos Filipes em Portugal e no Brasil (1580 -1668). Lisboa, Editora Colibri, 1994.

SCHWARTZ, Stuart. Segredos internos: engenhos e escravos na sociedade colonial, 1550 - 1835. São Paulo, Companhia das Letras, 1988.

SOUSA, Ivo Carneiro de. A Rainha D. Leonor (1458-1525): Poder, misericórdia e espiritualidade no Portugal do Renascimento. São Paulo, Fundação Calouste Gulbenkian, 2002.

SOUZA, Laura de Mello e. Desclassificados do Ouro - A pobreza mineira no século XVIII. Rio de Janeiro, Editora Graal, 1990. . História de Vida Privada no Brasil. São Paulo, Companhia das Letras, 1997. 
SERRÃO, Joaquim Veríssimo. O Tempo dos Filipes em Portugal e no Brasil (1580-1688). Lisboa, Edições Colibri - História, 1994.

VAINFAS, Ronaldo et al. Vieira, vida e palavra. São Paulo, Edições Loyola, 2008.

VALVERDE, Lola. Illegitimacy and the abandonment of children in the Basque Country (1550-1800). In HENDERSON, John (et al.). Poor Women and Children in the European Past. Londres, Routledge, 1994.

VIEIRA, Antônio. Sermões, Tomos I e II (organização de Alcir Pécora). São Paulo, Editora Hedra, 2003. , Escritos Históricos e Políticos. (organização de Alcir Pécora) São Paulo, Editora Martins Fontes, 1995. , Escritos Instrumentais sobre os Índios (organização de Cláudio Giordano e José Carlos Sebe Bom Meihy). São Paulo, EDUC, 1992.

, Cartas (Tomo I) (organização de J. Lúcio de Azevedo). Lisboa, Casa da Moeda / Imprensa Nacional, 1970.

VIEIRA, VIDA E PALAVRA. São Paulo, Edições Loyola, 2008.

WEBER, Max. A Ética Protestante e o Espírito do Capitalismo. São Paulo, Editora Pioneira, 1979. 